\title{
Functionalization reactions of calixarenes
}

\author{
Wanda Sliwa* and Malgorzata Deska \\ Jan Dlugosz University, Institute of Chemistry, Environmental Protection and Biotechnology, 42- \\ 200 Czestochowa, Armii Krajowej 13/15 Street, Poland \\ E-mail:w.sliwa@ajd.czest.pl
}

\begin{abstract}
In this review examples of functionalization reactions of calixarenes are presented with those involving the wide rim being presented first, followed by those involving the narrow rim, and then by reactions involving functionalization of both rims. The application possibilities of the obtained compounds are also described.
\end{abstract}

Keywords: Calixarenes, chirality, conformation, functionalization, narrow rim, wide rim

\section{Table of Contents}

1. Introduction

2. Functionalization of the wide rim of calixarenes

3. Functionalization of the narrow rim of calixarenes

4. Functionalization of both rims of calixarenes

5. Conclusion

6. Acknowledgement

7. References

\section{Introduction}

Calixarenes are widely studied due to their interesting properties, ${ }^{1-9}$ including the fact that they are valuable receptors besides cyclodextrins, ${ }^{10-13}$ and cucurbiturils. ${ }^{14-17}$ An advantageous feature of calixarenes is their easy availability. Functionalization of calixarenes at their wide and at their narrow rims, permits the synthesis of a variety of derivatives having desired properties and is the topic of the present review.

The large number of publications dealing with calixarenes is a reflection of their various applications. Calixarenes are receptors for neutral and charged species, ${ }^{18-20}$ they form complexes with metal ions, ${ }^{21-23}$ and are promising for environment protection due to their ability to extract 
cesium and lanthanides from radioactive waste. ${ }^{24,25}$ They are of interest for the design of sensor, ${ }^{26-28}$ and catalysts, ${ }^{29,30}$ and are useful in chiral recognition, ${ }^{31,32}$ as well, polymers, ${ }^{33-35}$ and supramolecular structures, ${ }^{36-38}$ containing calixarenes exist. It is worthnoting that calixarenes may be applied in the design of metal-organic nanotubes, ${ }^{39,40}$ vesicles, ${ }^{41}$ and nanoparticles. ${ }^{42}$ Attention should be paid also to capped calixarenes, ${ }^{43}$ and calixtubes, ${ }^{44}$ along with their complexation properties.

Compounds related to calixarenes include resorcinarenes ${ }^{45-47}$ bearing two hydroxyl groups on the phenyl moieties able to form cavitands ${ }^{48,49}$ which are precursors of capsules. ${ }^{50}$ An interesting class are the pyrogallolarenes built from pyrogallol units ${ }^{51}$ which are components of metal-organic nanocapsules. ${ }^{52}$

Related to calixarenes also are the calixcrowns, ${ }^{53,54}$ which are calixarenes bearing crown ether units; calixquinones, ${ }^{55,56}$ containing one or two quinone units instead of phenol moieties of calixarenes; calixpyrroles, ${ }^{57-59}$ built from pyrrole units, and calixphyrins, ${ }^{60,61}$ formed by the reduction of porphyrins. Pillarenes, ${ }^{62-64}$ in which benzene rings are linked by para, and not by meta positions as in calixarenes should also be included. A special group are the thia, oxa and azacalixarenes, in which the linking methylene groups of calixarenes are formally replaced by sulfur, ${ }^{65-67}$ oxygen, ${ }^{68-70}$ or nitrogen, ${ }^{71-73}$ atoms, respectively.

This contribution is a continuation of our previous works concerning calixarenes, ${ }^{74}$ their complexes with metal ions, ${ }^{75,76}$ covalently and noncovalently bound calixarene assemblies, ${ }^{77}$ and cavitands, ${ }^{78}$ forming dimeric, ${ }^{79}$ as well as trimeric and hexameric, ${ }^{80}$ capsules. Since the amount of reports dealing with calixarenes is enormous, only selected examples are described in this review. The text consists of three chapters; two of them concern functionalization of the wide and the narrow rims of calixarenes, and in the third chapter the functionalization of both rims is presented.

\section{Functionalization of the wide rim of calixarenes}

Many calixarenes functionalized at the wide rim are known, ${ }^{81-86}$ It should be noted that functionalization of the wide rim is more difficult than of the narrow rim. Functionalization of the wide rim requires protection of the narrow rim hydroxyl groups and also removal of the $t$-butyl groups from the wide rim. Some selected examples of functionalizations of calixarene at the wide rim are shown below.

In a study of calixarene monophosphines as supramolecular receptors, reactions leading to 1-4 have been performed. ${ }^{87}$ The synthesis of calixarene monophosphines $\mathbf{1}$ and $\mathbf{2}$ begins with the nickelcatalyzed reactions of dibromocalixarene 5 and of tetrabromocalixarene 6 with $\mathrm{Ph}_{2} \mathrm{POEt}$ affording calixarene phosphine oxides $\mathbf{7}$ and $\mathbf{8}$, which were reduced with $\mathrm{PhSiH}_{3}$ to give $\mathbf{1}$ and $\mathbf{2}$, respectively. 


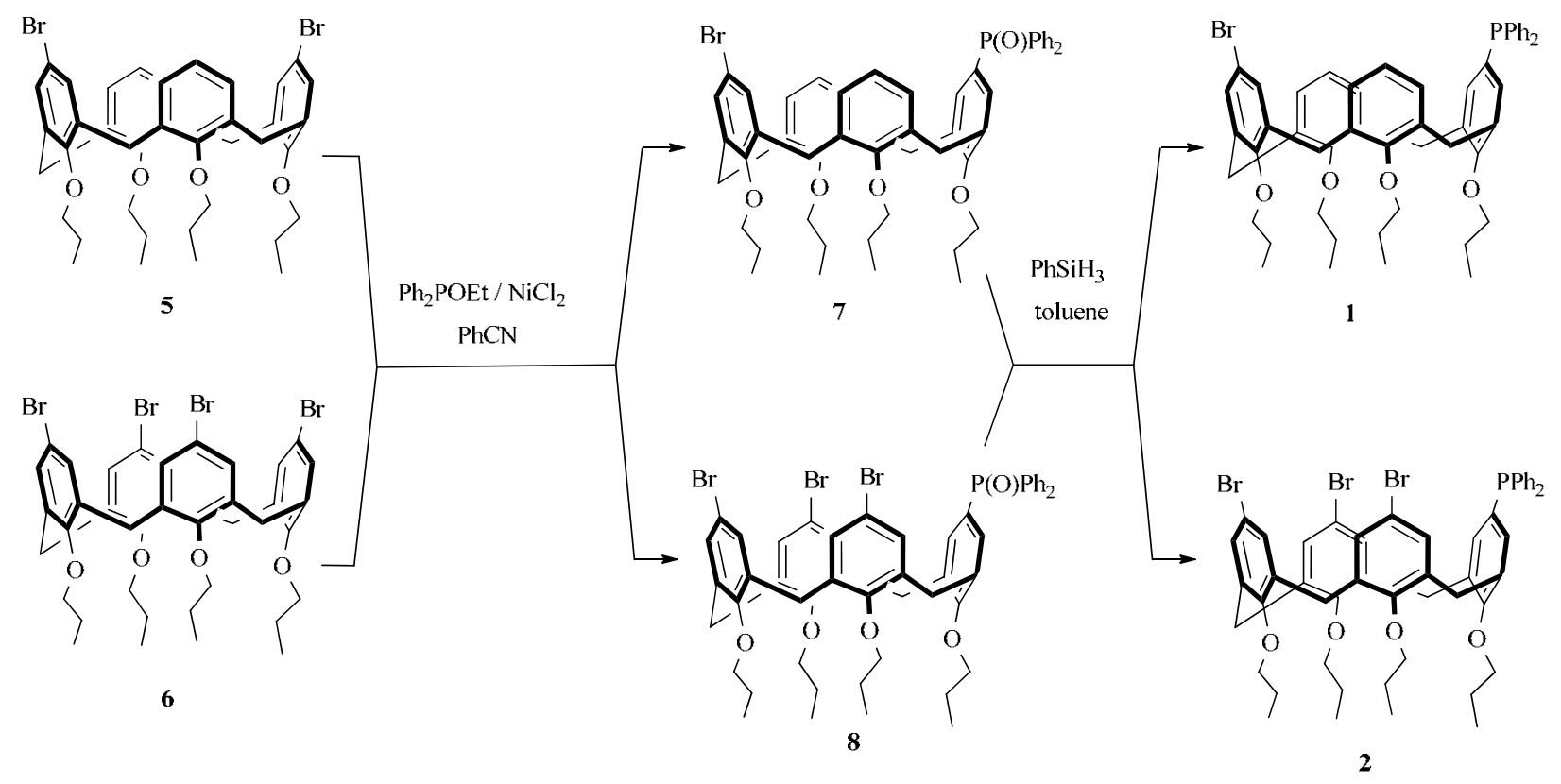

\section{Scheme 1}

The synthesis of $\mathbf{3}$ and $\mathbf{4}$ involves the Suzuki-Miyaura coupling of $\mathbf{7}$ and $\mathbf{8}$ with $p$-tolylboronic acid yielding $\mathbf{9}$ and 10, which upon reduction afford $\mathbf{3}$ and $\mathbf{4}$.

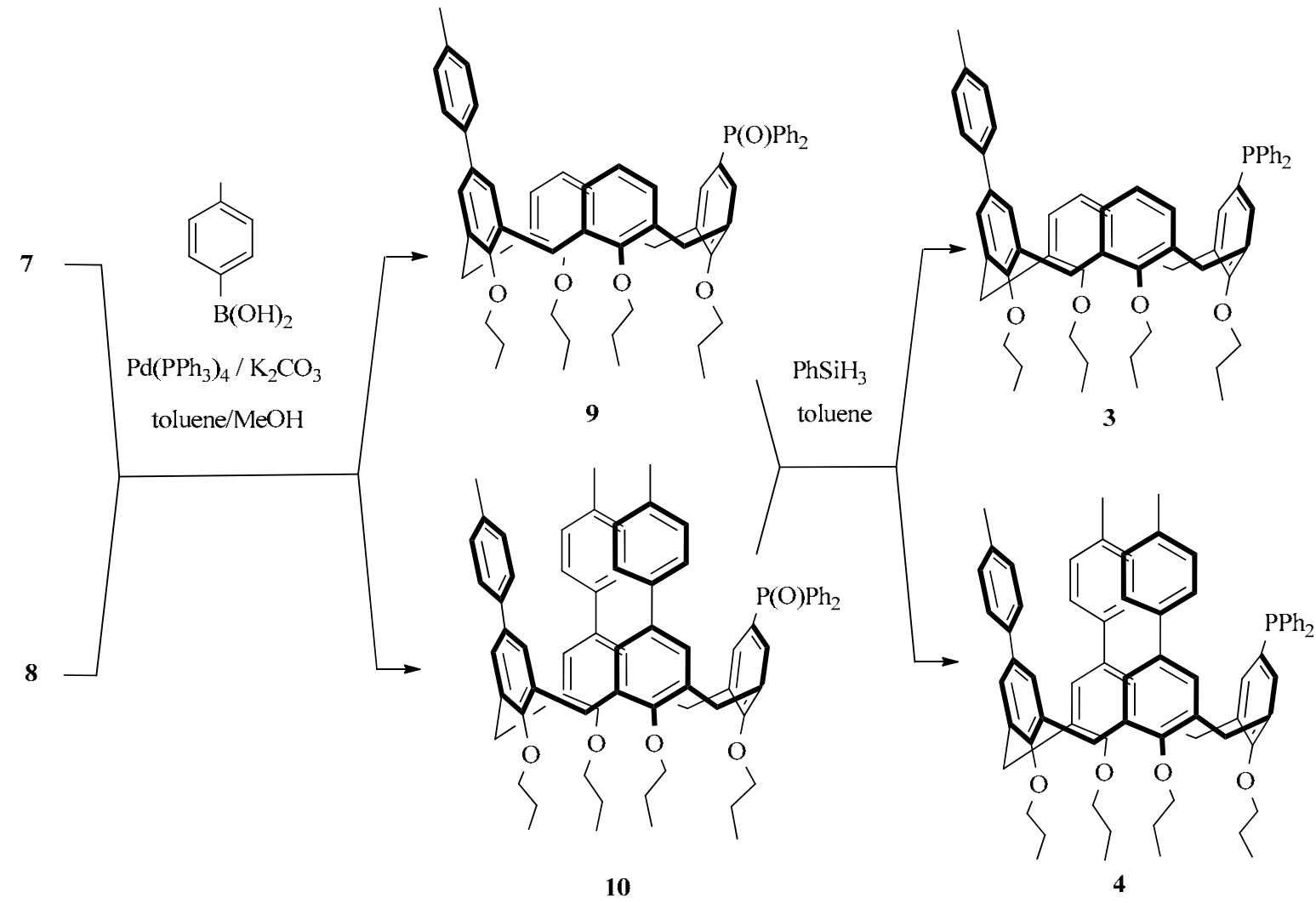

\section{Scheme 2}


It was found that compounds $\mathbf{1 - 4}$ form with $\left[\mathrm{RuCl}_{2}(p \text {-cymene })\right]_{2}$ inclusion complexes; the complexation of 1 and 3 leads to $\left[\mathrm{RuCl}_{2}(p\right.$-cymene $\left.) \mathrm{L}\right]$ complexes $11(\mathrm{~L}=\mathbf{1})$ and $12(\mathrm{~L}=\mathbf{3})$.

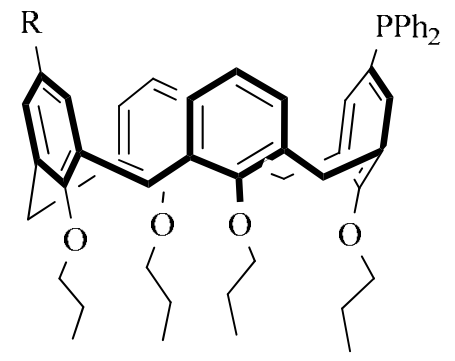

$\mathbf{1} \mathrm{Br}$
$\mathbf{3} p$ tolyl
$0.5\left[\operatorname{RuCl}_{2}(p \text { cymene })\right]_{2}$ $\mathrm{CH}_{2} \mathrm{Cl}_{2}$

\section{Scheme 3}

In continuation of the above experiments concerning calixarene monophosphines, compounds 13-17 have been synthesized for use in preparation of Suzuki-Miyaura cross-coupling catalysts. ${ }^{88}$ Thus, bromocalixarene 18 was alkylated in the presence of sodium hydride to afford 19-22 which, upon halogen-lithium exchange, followed by reaction with $\mathrm{Ph}_{2} \mathrm{PCl}$ yielded 13-16. Debenzylation of 14 using $\mathrm{AlCl}_{3}$ gave 17.

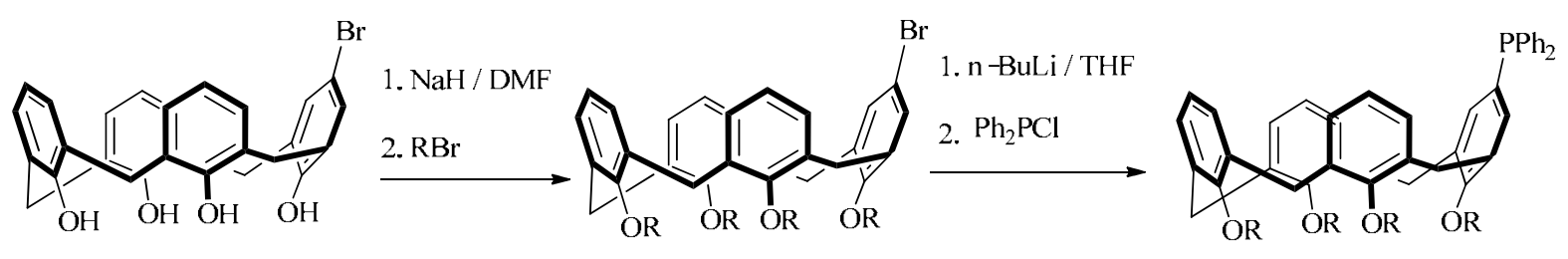

18

$19-22$

$19,13 \frac{\mathrm{R}}{\mathrm{n}-\mathrm{C}_{6} \mathrm{H}_{13}}$

$13-16$

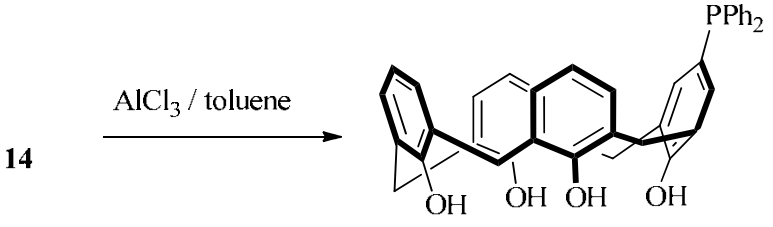

20, $14 \mathrm{CH}_{2} \mathrm{Ph}$

21, $15 \quad \mathrm{H}_{2} \mathrm{C} \longrightarrow \mathrm{OMe}$

22, 16

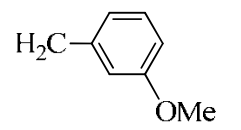

17

\section{Scheme 4}


In order to investigate the coordination ability of phosphines 13-17, the reaction of 14 with $\left[\mathrm{PdCl}_{2}(\mathrm{cod})\right]$ leading to trans-23 and cis-24 was performed. ${ }^{88}$ It was found that 23 upon treatment with $\mathrm{CDCl}_{3}$ undergoes isomerization into 24.
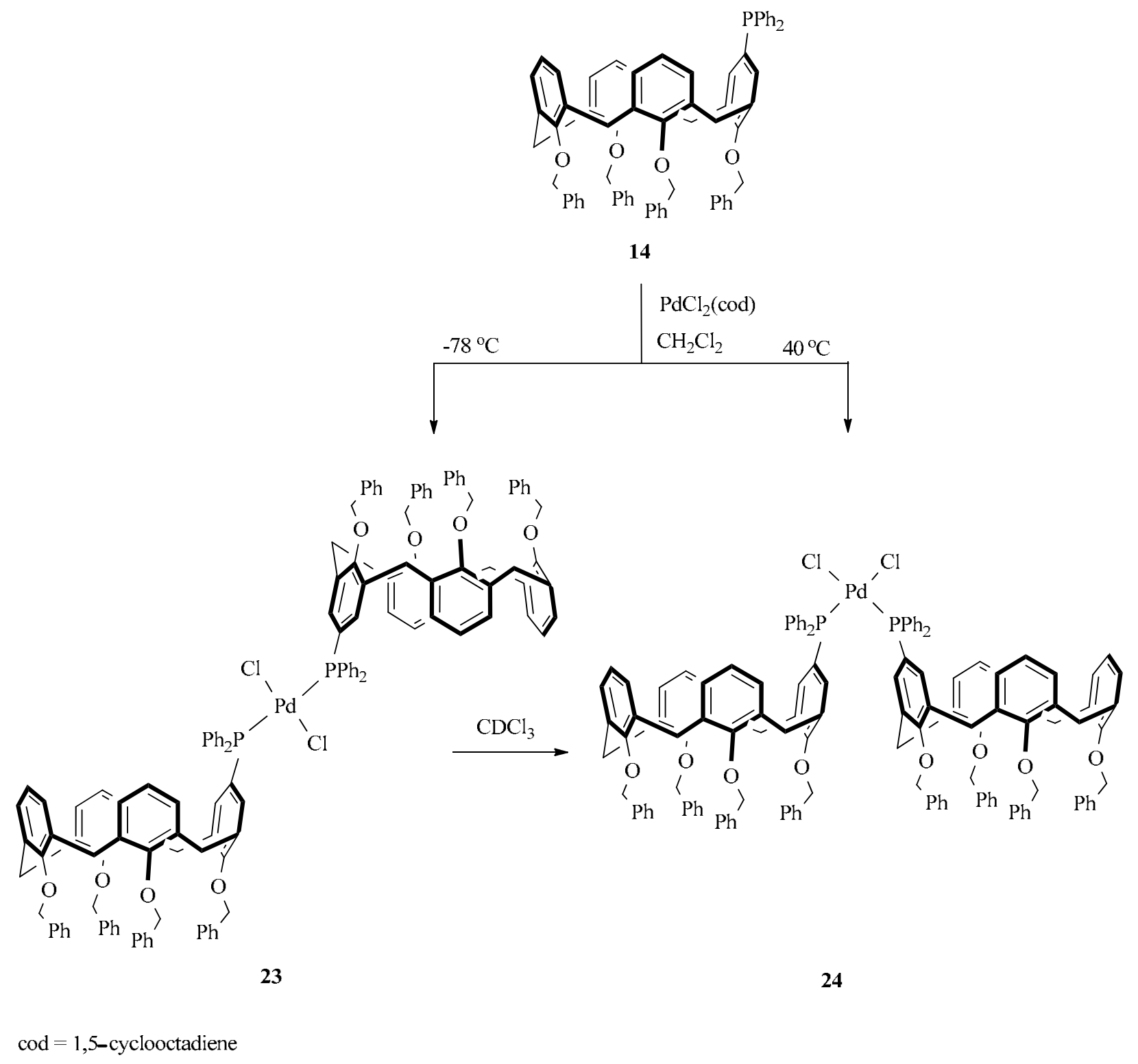

\section{Scheme 5}

The reaction of 14 with $\left[\mathrm{Pd}\left(o-\mathrm{C}_{6} \mathrm{H}_{4} \mathrm{NMe}_{2}\right) \mathrm{Cl}\right]_{2}$ affords complex 25 which was treated with $\mathrm{AgBF}_{4}$ in $\mathrm{THF}$ to give the complex 26; recrystallization of $\mathbf{2 6}$ performed by slow diffusion of hexane into a commercial undried dichloromethane solution of $\mathbf{2 6}$ yields the aquo complex $\mathbf{2 7}$. 


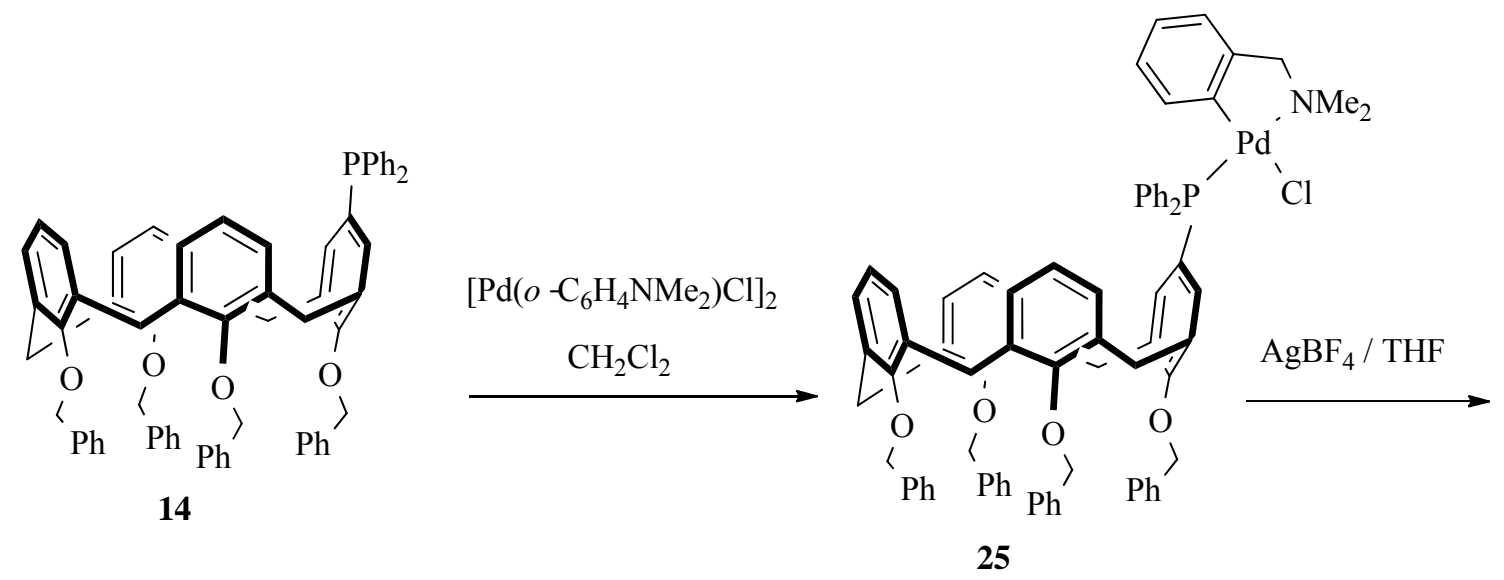

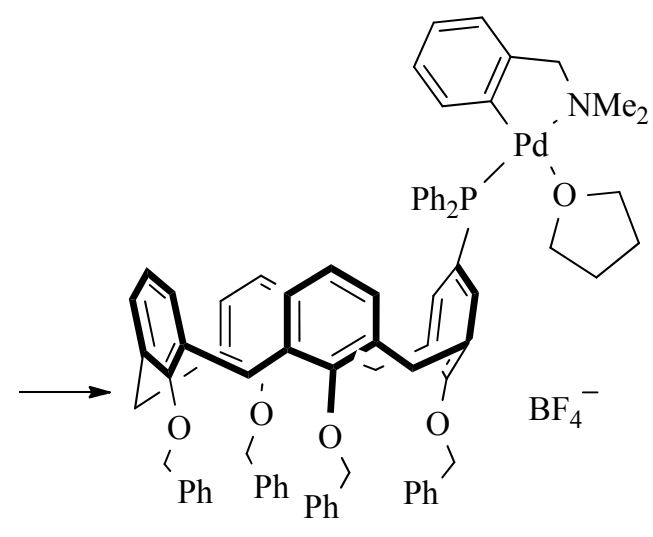

26

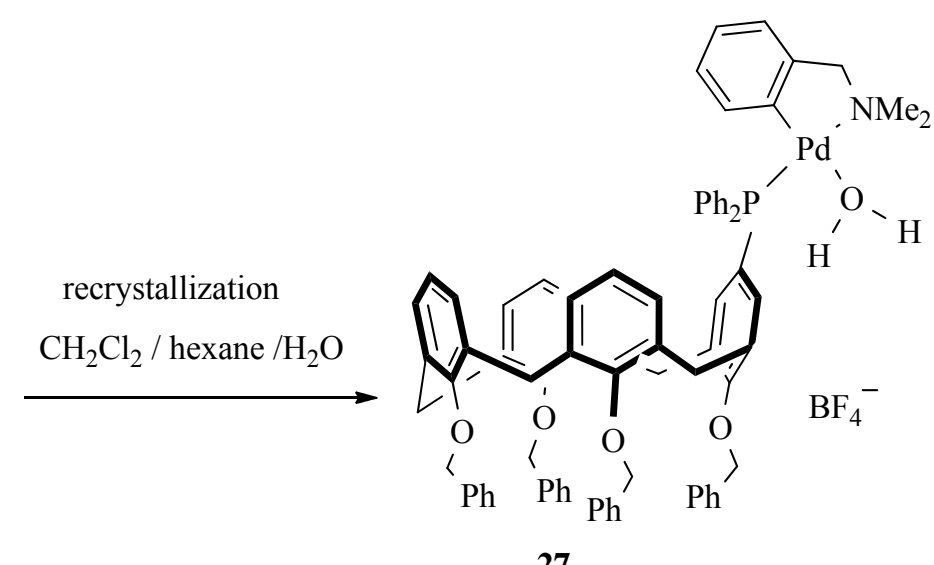

27

\section{Scheme 6}

For the study of Suzuki-Miyaura cross-coupling reactions, the catalysts were generated in situ by mixing the respective monophosphines from among 13-17 with the palladium precursor. In these experiments, bromobenzene, 2-3-and 4-bromotoluene, 2-and 4-bromoanisole, 1-bromonaphthalene and 2-bromo-6-methoxynaphthalene served as aryl bromides, while [ $\left.\mathrm{Pd}(\mathrm{OAc})_{2}\right],\left[\mathrm{Pd}(\mathrm{dba})_{2}\right]$ and $\left[\mathrm{PdCl}_{2}(\mathrm{cod})\right]_{2}$ were used as the palladium precursors; $\mathrm{NaH}, \mathrm{NaOH}, \mathrm{KOH}, \mathrm{K}_{2} \mathrm{CO}_{3}, \mathrm{Cs}_{2} \mathrm{CO}_{3}$ and $\mathrm{CsF}$ were used as the bases.

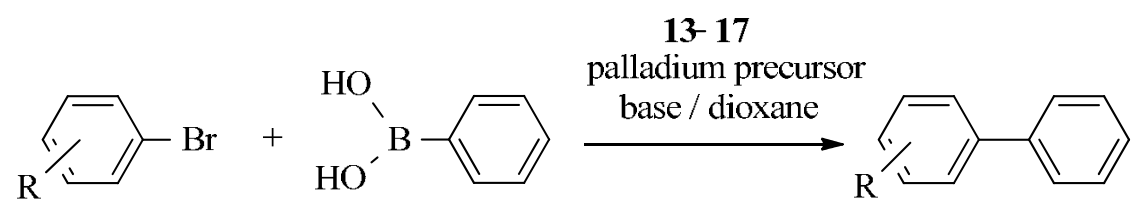

\section{Scheme 7}

It was found that combining each of the monophosphines 13-17 with $\left[\mathrm{Pd}(\mathrm{OAc})_{2}\right]$ and $\mathrm{NaH}$ in dioxane, yielded a highly efficient catalytic system for the Suzuki-Miyaura cross-coupling of aryl bromides with phenylboronic acid. Notably also, these catalysts remained stable for several days. ${ }^{88}$ 
In order to study phosphorylation which occurs in biochemical processes, the phosphatase inhibitory properties of compounds $\mathbf{2 8}$ and $\mathbf{2 9}$ have been investigated. ${ }^{89}$ In these experiments it was found that the introduction of methylenebisphosphonic acid $\mathbf{2 8}$ onto calix[4]arene $\mathbf{3 0}$ to form compounds such as $\mathbf{3 3}$ and 34, results in the efficient inhibition of alkaline phosphatase whereas this inhibition of $\mathbf{2 8}$ itself is only very low. For these phosphatase inhibitory studies, calixarenes $\mathbf{3} 3$ and 34 containing one and two units of $\mathbf{2 8}$, respectively, were synthesized via the reactions of calixarene aldehydes 31 and 32.<smiles>O=P(O)(O)CP(=O)(O)O</smiles>

28<smiles>O=P(O)(O)C(c1ccc(O)cc1)P(=O)(O)O</smiles>

29

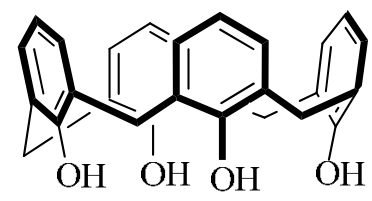

30

\section{Scheme 8}

Treatment of calixarenes $\mathbf{3 1}$ and 32 with sodium diethylphosphite generated in situ from diethylhydrogenphosphite and sodium in dioxane afforded esters 35 and 36 which were then converted to the corresponding acids 33 and 34 by reaction with $\mathrm{Me}_{3} \mathrm{SiBr}$ followed by methanol.

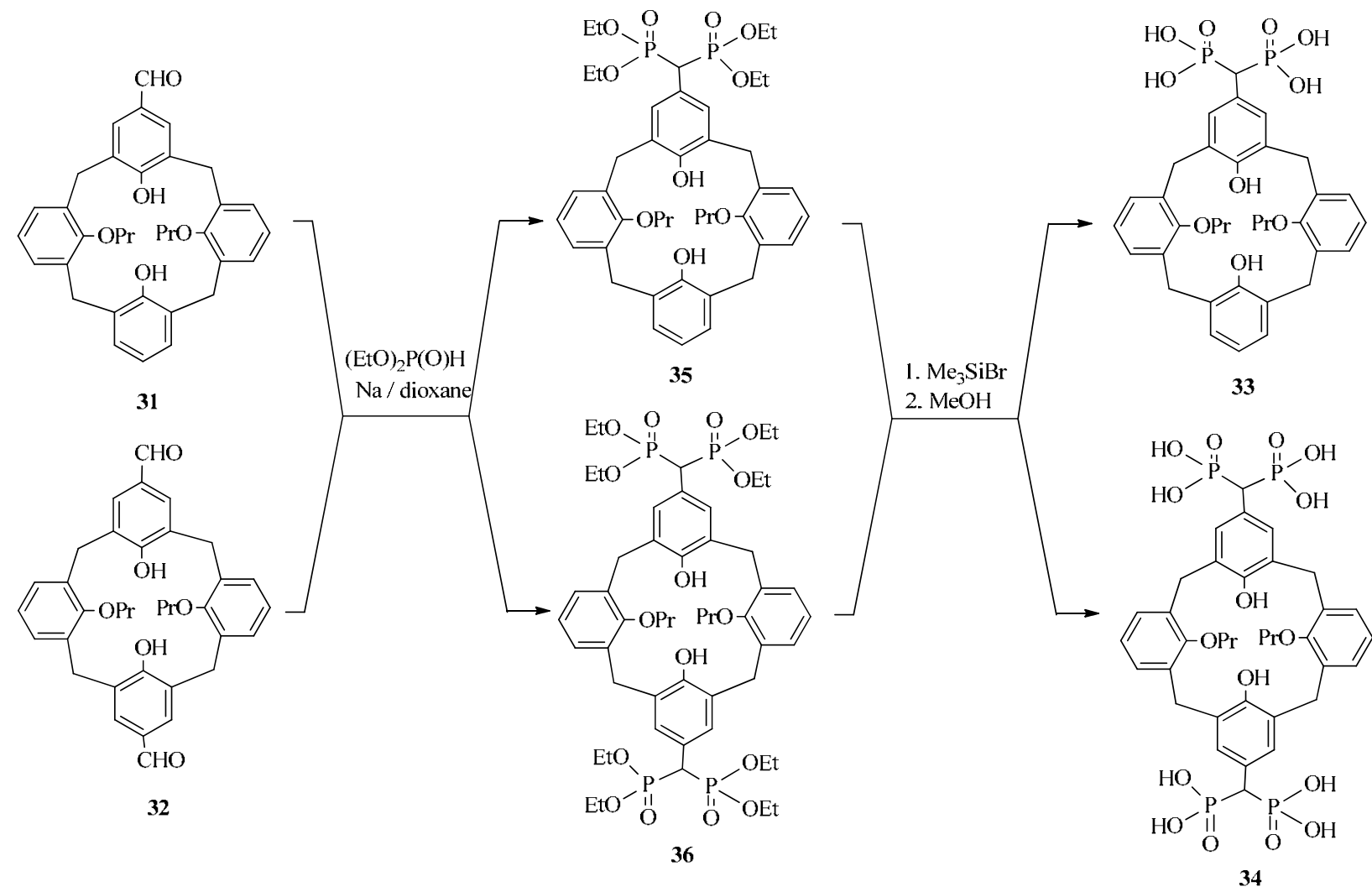

\section{Scheme 9}


The phosphatase inhibitory activities of 28, 29, 33, 34 and 36 which were found to decrease in the order $34>33>29>\mathbf{2 8}$ were examined in the hydrolysis reactions of $p$-nitrophenylphosphate catalyzed by calf intestine alkaline phosphatase. The esterified calixarene $\mathbf{3 6}$ showed no inhibitory activity and therefore one may conclude that the free phosphonyl groups are responsible for the inhibitory properties of 28, 29, 33 and 34. The activity of these compounds as phosphatase inhibitors likely results from their coordination to the metal $\left(\mathrm{Zn}^{2+}\right.$ and $\left.\mathrm{Mg}^{2+}\right)$ ions in the enzyme active site.

Properties of a photolabile calixarene bearing an internal sensitizer have been examined. Considering the fact that $\alpha$-hydroxyalkyldithianes are known to undergo photofragmentation in the presence of an electron transfer sensitizer, such as benzophenone, the synthesis of calixarene 37 bearing two photocleavable dithianylhydroxymethyl groups and two benzophenonecarboxylate groups was performed. It was found that $\mathbf{3 7}$ indeed undergoes a photoinduced fragmentation. ${ }^{90}$

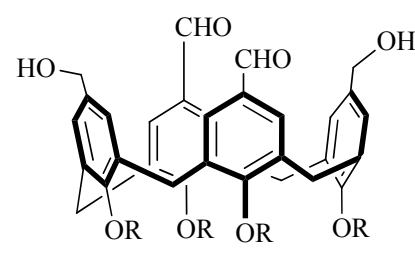

38

$\mathrm{R}=\mathrm{CH}_{2} \mathrm{CH}_{2} \mathrm{OEt}$
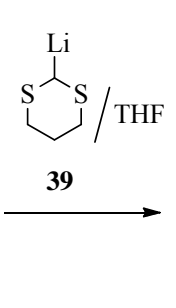$$
\mathrm{CH}_{2} \mathrm{CH}_{2} \mathrm{OEt}
$$

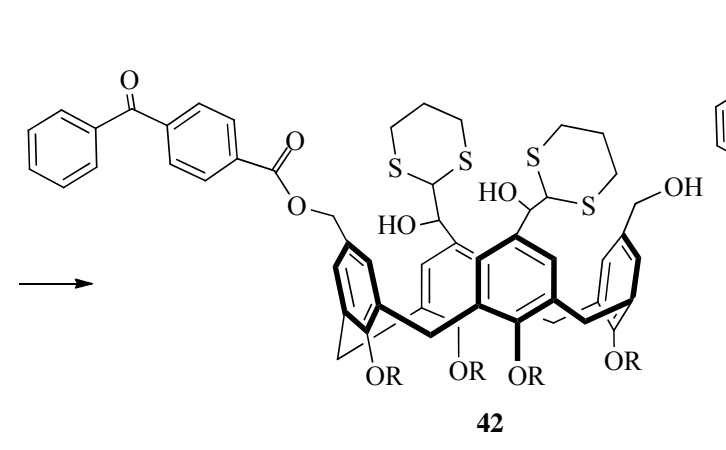

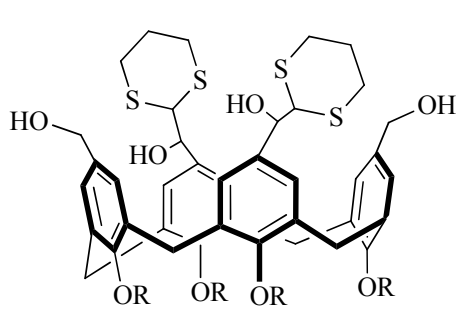

40
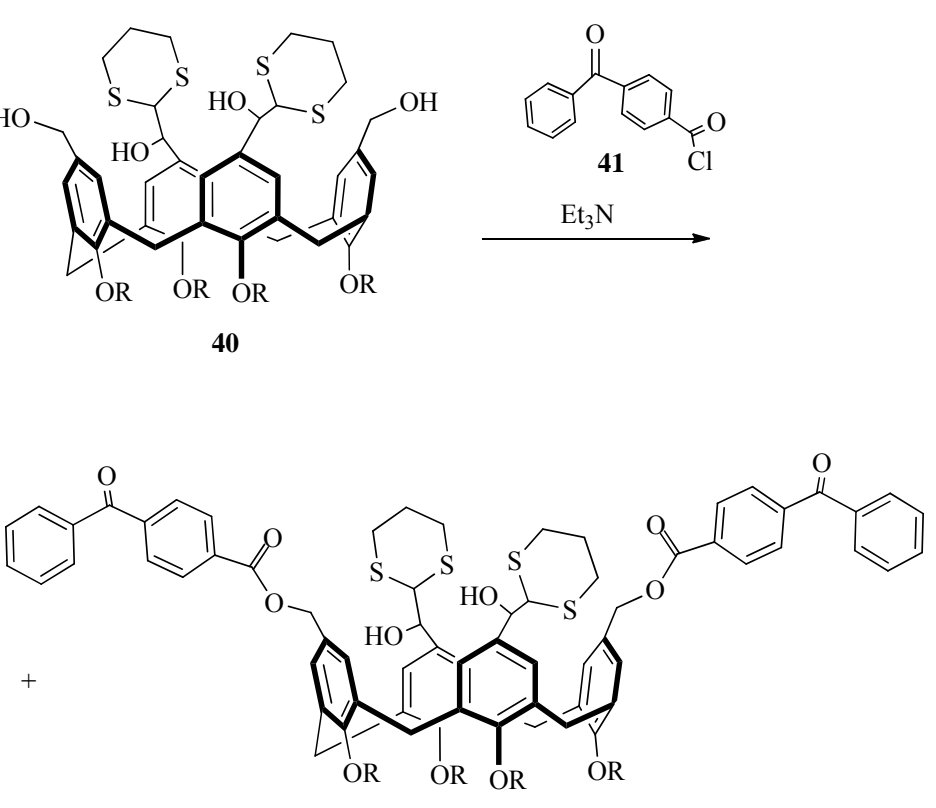

37

\section{Scheme 10}

The synthesis of $\mathbf{3 7}$ begins with the reaction of dialdehyde 38 with lithiated dithiane 39 to afford compound 40. Benzophenone-4-carboxylic acid was used as the tethered internal sensitizer and it was coupled to $\mathbf{4 0}$ via its chloride $\mathbf{4 1}$ formed by treatment with oxalyl chloride. The coupling of $\mathbf{4 0}$ with 41 in the presence of triethylamine yielded the mono and disubstituted products 42 and 37, respectively.

For the photochemical study, 37 was irradiated with a medium pressure mercury lamp; the process was monitored by ${ }^{1} \mathrm{H}$ NMR and confirmed the ability of 37 to self-sensitized photofragmentation.

In a study of calixarenes with ferrocenyl redox-active units, ${ }^{91}$ calixarenes 43 and 44 bearing ferrocenyl units were synthesized for investigation of their electrochemical properties. ${ }^{92}$ The synthesis involves the reaction of calixarene dialdehyde 45 with 4 -ferrocenylaniline, affording the 
Schiff base 43, which upon reduction, yields calixarene 44 . It was found that 43 and 44 electrochemically recognize $\mathrm{La}^{3+}, \mathrm{Ce}^{3+}, \mathrm{Pb}^{2+}$ and $\mathrm{Cu}^{2+}$ ions and the study of the extraction properties toward metal ions showed selectivity of $\mathbf{4 4}$ for $\mathrm{Cu}^{2+}, \mathrm{Fe}^{3+}, \mathrm{Pb}^{2+}$ and $\mathrm{Cd}^{2+}$ ions over $\mathrm{Co}^{2+}$ and $\mathrm{Ni}^{2+}$.

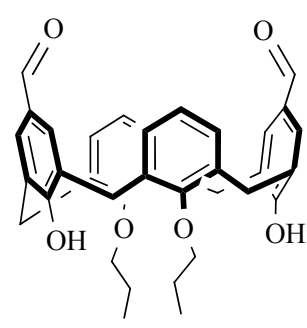

45
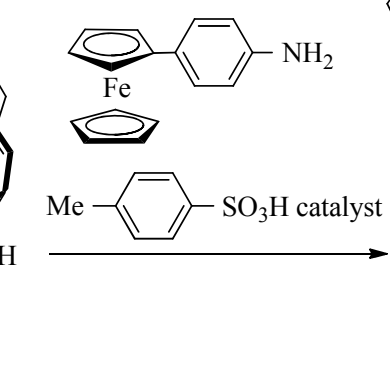

\section{Scheme 11}

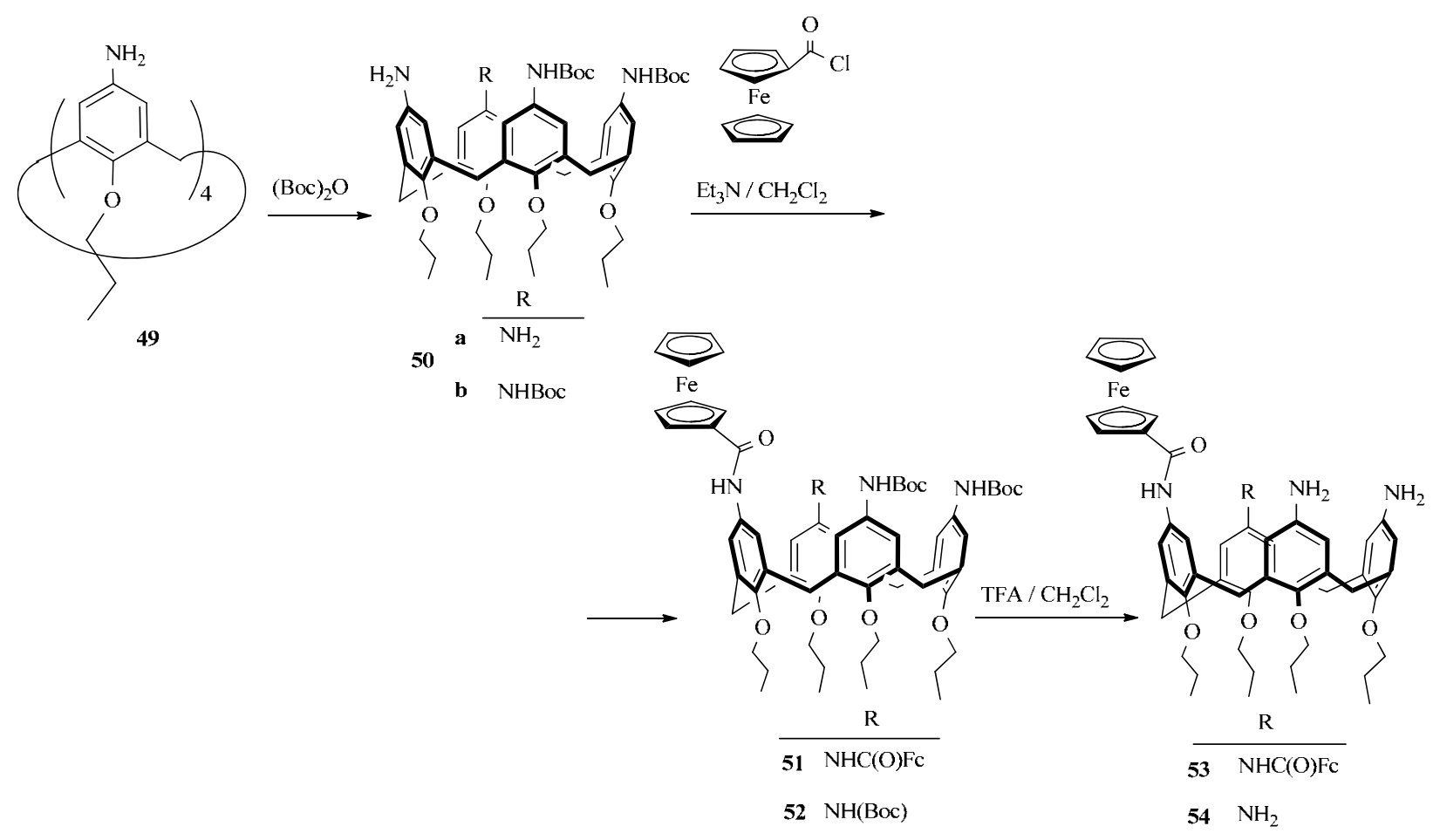

\section{Scheme 12}


Redox-active anion sensors have also been widely investigated and the use of ferrocene units in these species should be noted. It has been established that anion sensors adsorbed on surfaces in SAMs are advantageous since they are robust and portable, and moreover, the preorganization of receptors onto a surface enhances the thermodynamic driving force associated with receptor/analyte binding. With these considerations in mind, the disulfide-functionalized calixarenes bearing ferrocene units, 46-48 were synthesized for construction of SAM redox-active anion sensors adsorbed on gold surfaces. ${ }^{93}$

The synthesis of 46 and 47 started with the reaction of tetraaminocalixarene 49 with BOC anhydride affording 50a and 50b which upon treatment with ferroceneacid chloride, give 51 and $\mathbf{5 2}$, respectively. Their deprotection by TFA leads to 53 and 54 which react with thioctic acid in the presence of the carbodiimide coupling reagent, EDC, yielding 46 and 47, respectively.

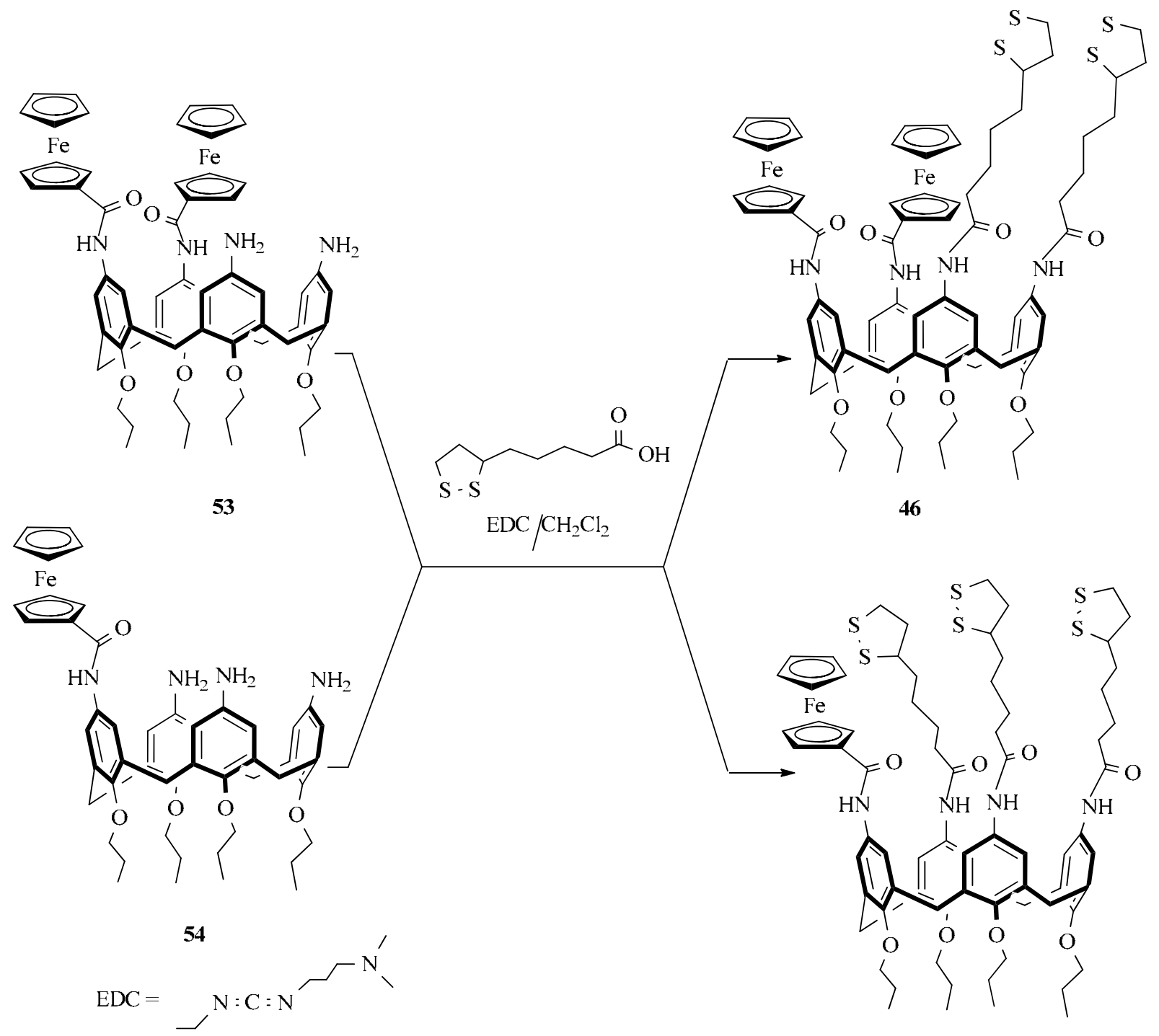

47

\section{Scheme 13}


In order to obtain $\mathbf{4 8}$ bearing the ferrocene unit linked by the urea moiety to the calixarene platform, the reaction of calixarene $50 \mathrm{~b}$ with isocyanatoferrocene leading to calixarene 55 was performed. Deprotection of 55 afforded 56, which upon treatment with thioctic acid and EDC, yielded 48.
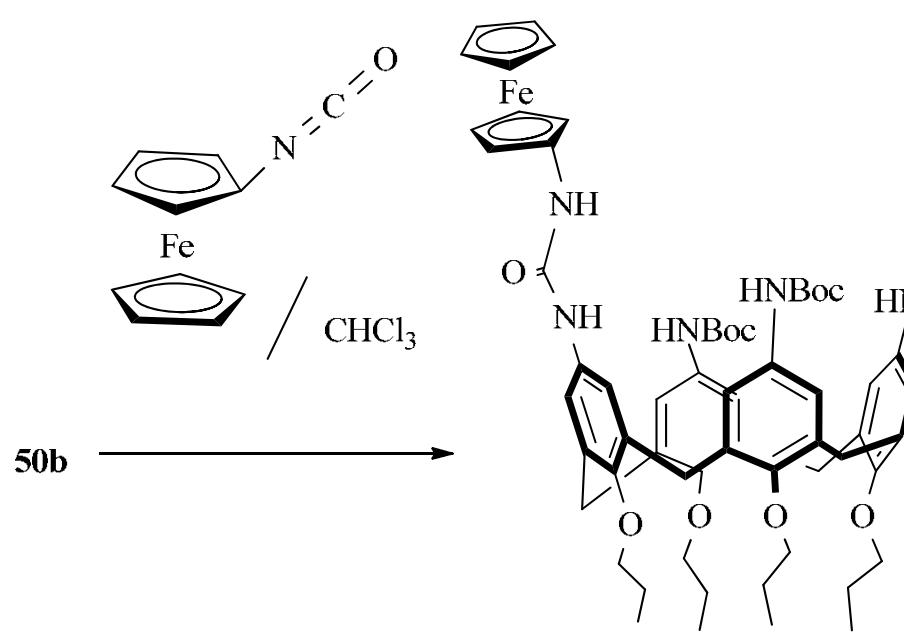

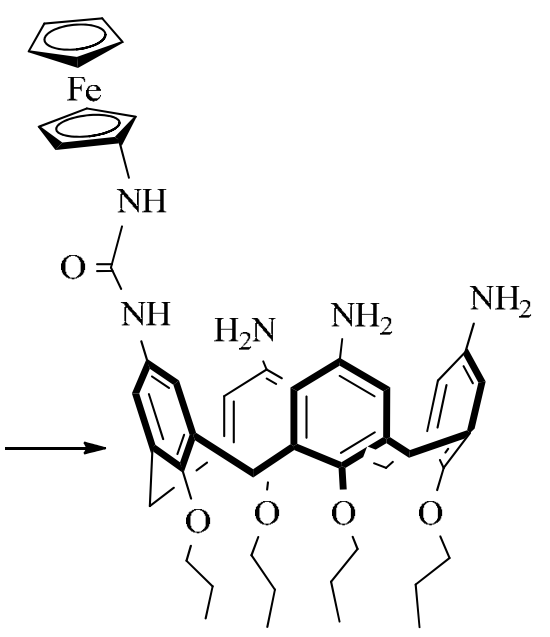

56
55

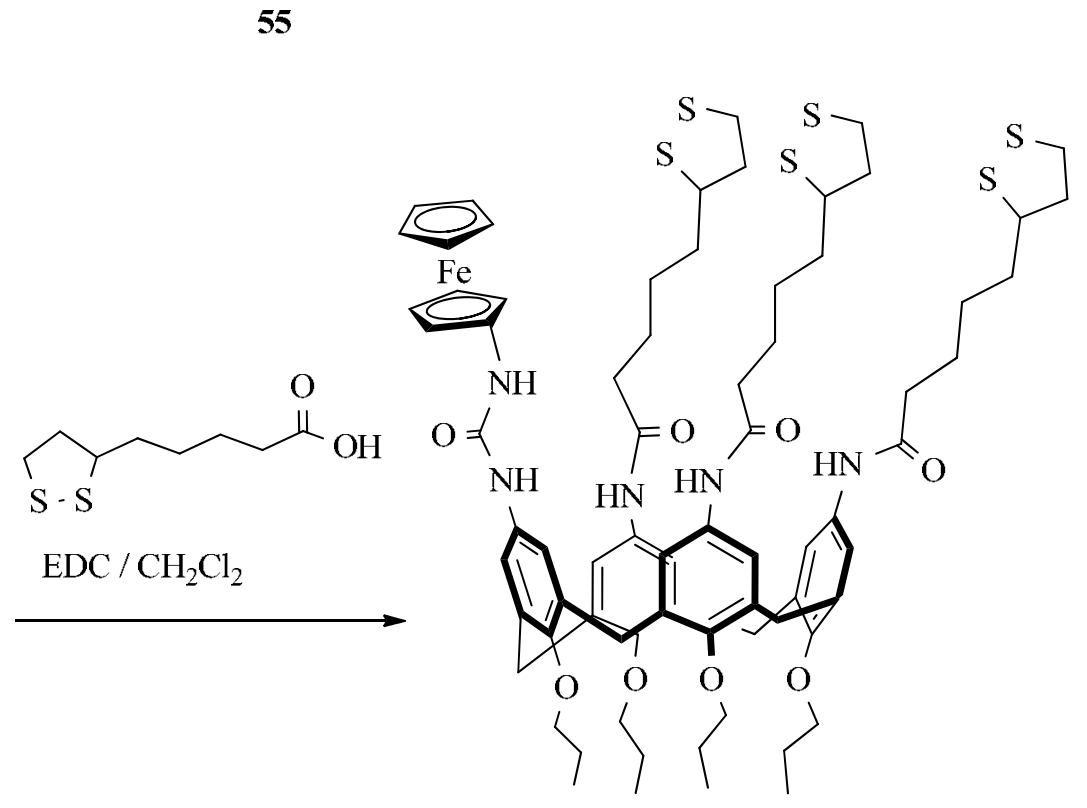

48

\section{Scheme 14}




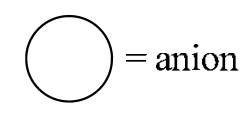

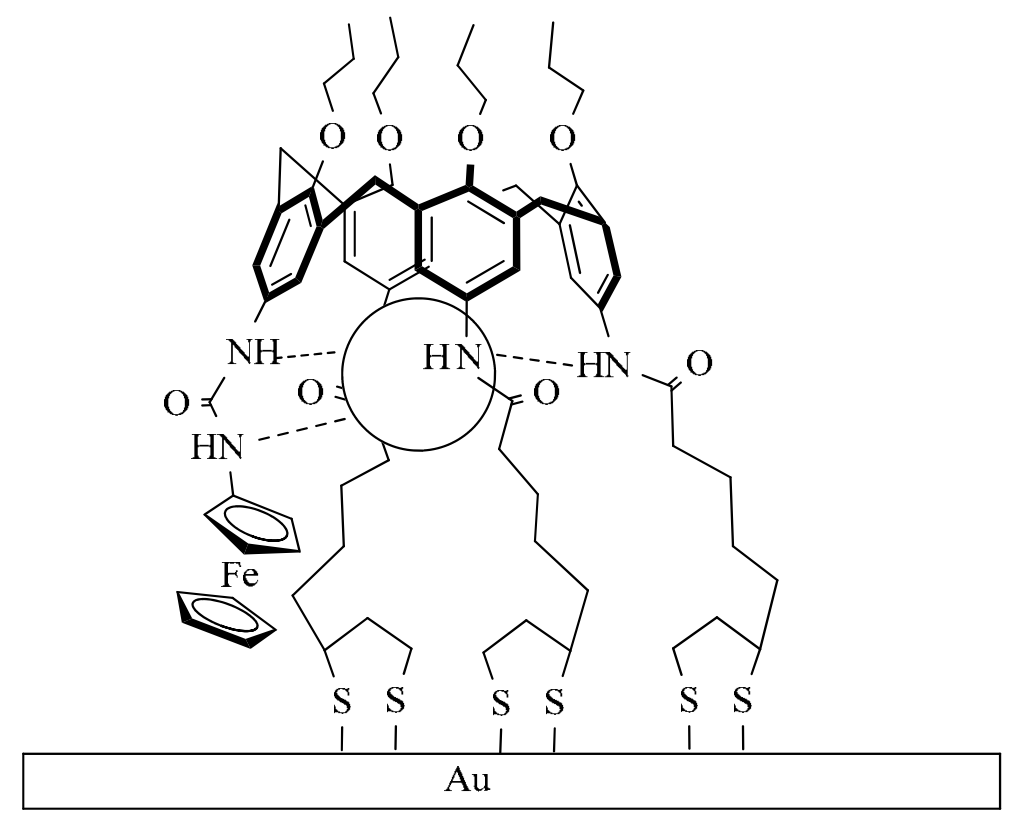

Anion sensing by receptor $\mathbf{4 8}$ adsorbed on gold electrode

\section{Scheme 15}

The anion sensing properties of 46-48 were studied using chloride, benzoate, dihydrogen phosphate and perrhenate anions. The cathodic shifts of the respective ferrocene/ferrocenium redox couple, resulting from the anion binding, were measured. It was established that SAMs of $\mathbf{4 8}$ adsorbed onto a gold electrode, selectively recognized perrhenate anions in aqueous solution in the presence of equimolar amount of dihydrogen phosphate, and are thus promising for the design of electrochemical anion sensors. ${ }^{93}$

Surfactant triscarboxycalixarenes 57a-k bearing $n$-alkyl chains with 1-12 carbon atoms have been synthesized with the aim of investigating their self-assembly properties. ${ }^{94}$ The synthesis begins with the treatment of calixarenes 58a-k with methyl iodide to form quaternary ammonium salts which, upon reaction with sodium cyanide yield tris(cyanomethyl)calixarenes 59a-k. The hydrolysis of 59a-k with alcoholic potassium hydroxide affords triscarboxycalixarenes 57a-k, all of which were found to form typical micelles in aqueous media at biologically relevant $\mathrm{pH} 6$ and $\mathrm{pH} 8$ values. 


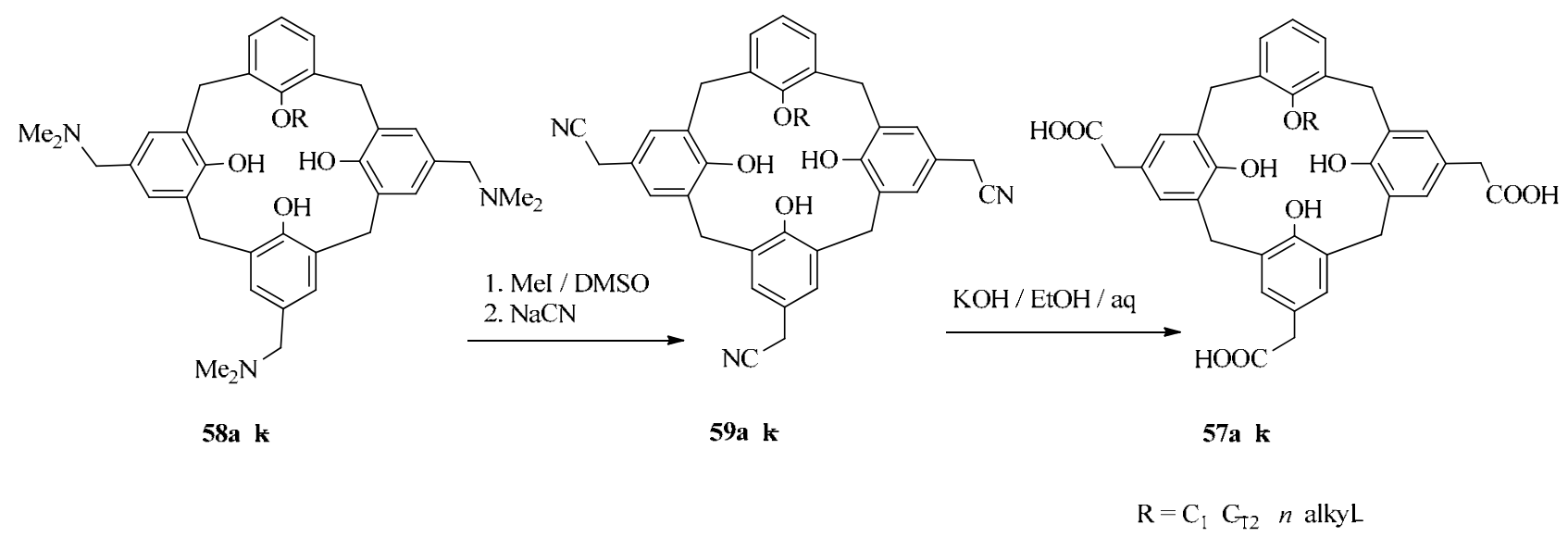

\section{Scheme 16}

A convenient method of regioselective functionalization of calix[8]arenes at the wide rim of aromatic rings 1 and 5 has been reported. This functionalization was performed using a protectiondeprotection procedure, the protected derivatives were the xylylene-bridged calix[8] arenes 61a and 61b, ${ }^{95}$ synthesized by the reaction of $p$-t-butylcalix[8]arene $\mathbf{6 0}$ with $m$-and $p$ bis(bromomethyl)benzenes, respectively. Hexamethylation of calixarenes 61a,b with methyl iodide afforded 62a,b and hexapropylation with $n$-propyl iodide afforded 63a,b. The removal of the xylylene bridge from 62a,b and 63a,b was achieved by hydrogenolysis $\left(\mathrm{H}_{2}, \mathrm{Pd} / \mathrm{C}\right)$ to give hexasubstituted calix[8]arenes 64 and 65 having two free hydroxyl groups on rings 1 and 5 .

It was found that upon treatment with nitric acid, 64 and 65 undergo selective ipso-nitration of rings 1 and 5 to afford 1,5-dinitrocalix[8]arenes 66 and 67, respectively. Calixarene 67 was exhaustively propylated to give 68, which upon reduction with $\mathrm{H}_{2} /$ Raney $\mathrm{Ni}$ yielded the corresponding diamino-derivative 69, whose amino groups can undergo further reactions. The selective de-t-butylation of $\mathbf{6 4}$ and 65 using $\mathrm{AlCl}_{3}$ in the presence of toluene or phenol gave de-tbutylated calix[8]arenes $\mathbf{7 0}$ and $\mathbf{7 1 .}$ 


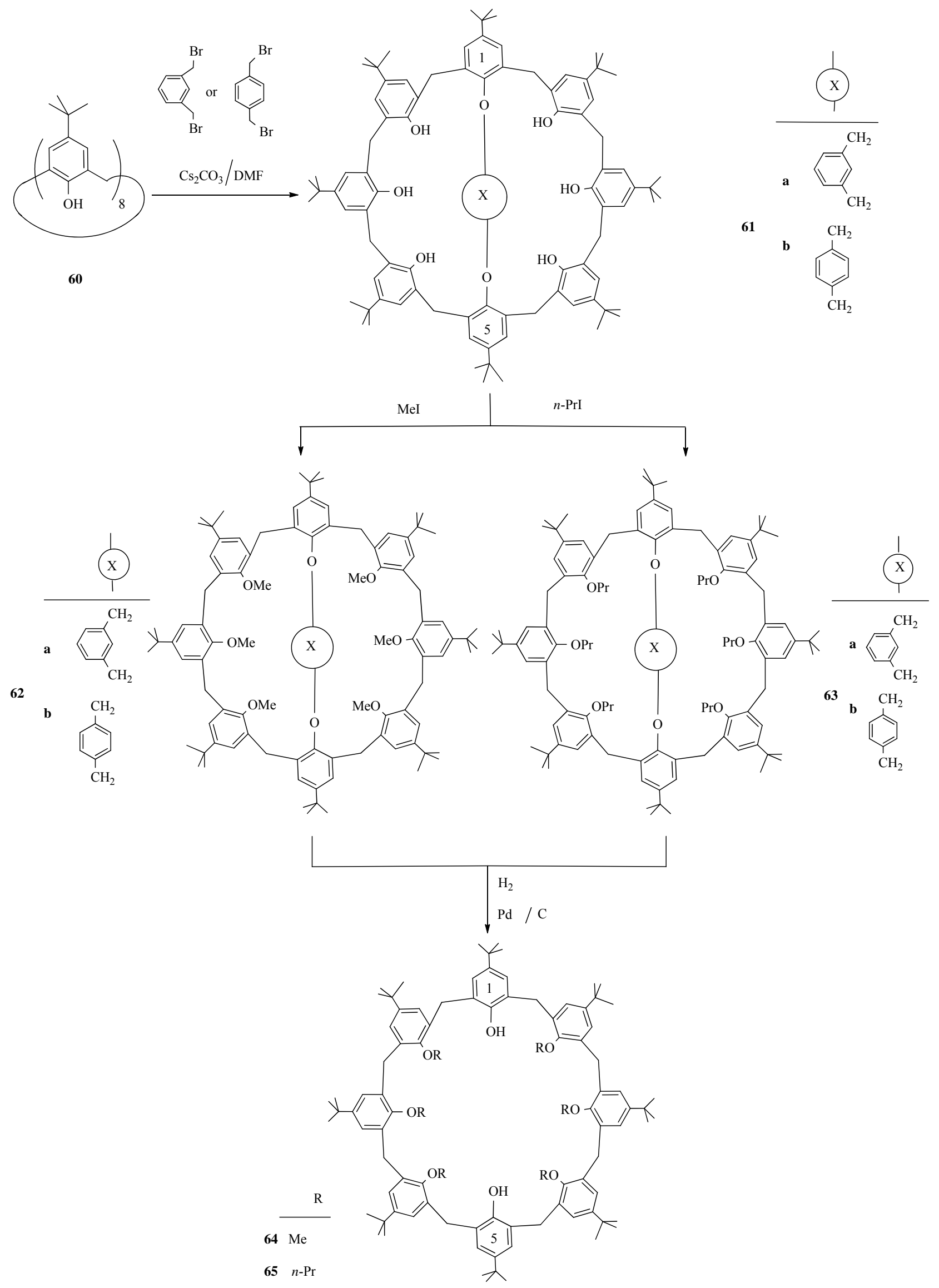




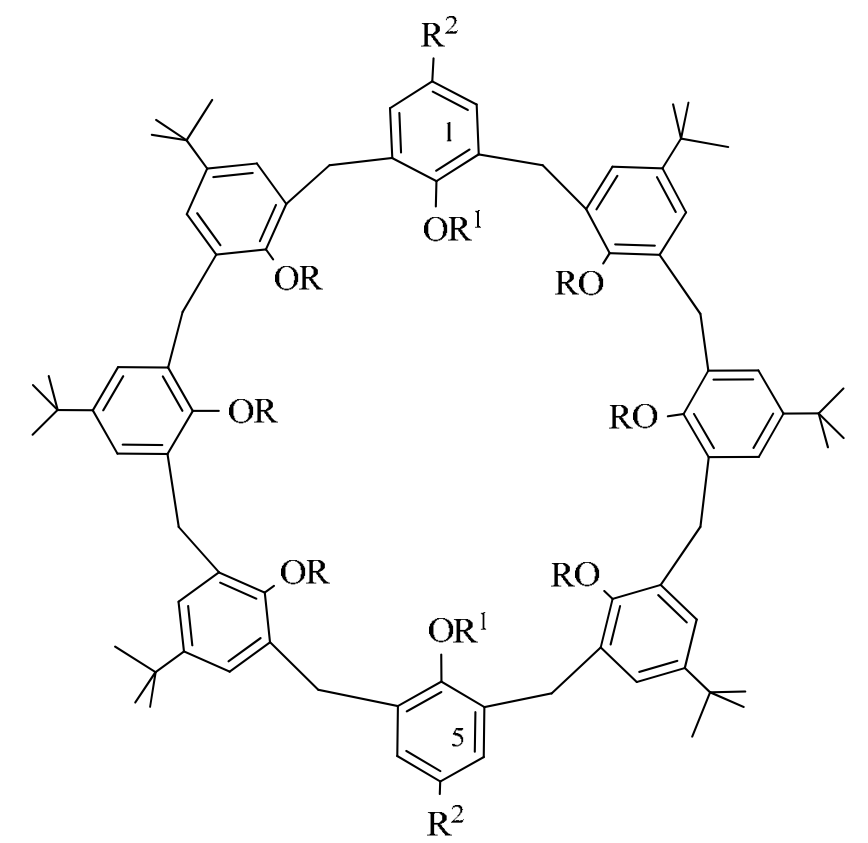

\begin{tabular}{cccc} 
& $\mathrm{R}$ & $\mathrm{R}^{1}$ & $\mathrm{R}^{2}$ \\
\hline $\mathbf{6 4}$ & $\mathrm{Me}$ & $\mathrm{H}$ & $t$-Bu \\
$\mathbf{6 5}$ & $n-\mathrm{Pr}$ & $\mathrm{H}$ & $t$-Bu \\
$\mathbf{6 6}$ & $\mathrm{Me}$ & $\mathrm{H}$ & $\mathrm{NO}_{2}$ \\
$\mathbf{6 7}$ & $n-\mathrm{Pr}$ & $\mathrm{H}$ & $\mathrm{NO}_{2}$ \\
$\mathbf{6 8}$ & $n-\mathrm{Pr}$ & $n-\mathrm{Pr}$ & $\mathrm{NO}_{2}$ \\
$\mathbf{6 9}$ & $n-\mathrm{Pr}$ & $n-\mathrm{Pr}$ & $\mathrm{NH}_{2}$ \\
$\mathbf{7 0}$ & $\mathrm{Me}$ & $\mathrm{H}$ & $\mathrm{H}$ \\
71 & $n-\mathrm{Pr}$ & $\mathrm{H}$ & $\mathrm{H}$ \\
& & &
\end{tabular}

\section{Scheme 18}

Upon oxidation with $\mathrm{Tl}\left(\mathrm{OCOCF}_{3}\right)_{3}$ in the presence of trifluoroacetic acid, calixarenes 64 and 65 afforded 1,5-calix[8]diquinones 72 and 73 which when subjected to reduction with $\mathrm{NaBH}_{4}$ gave 1,5-calix[8]dihydroquinones 74 and 75.

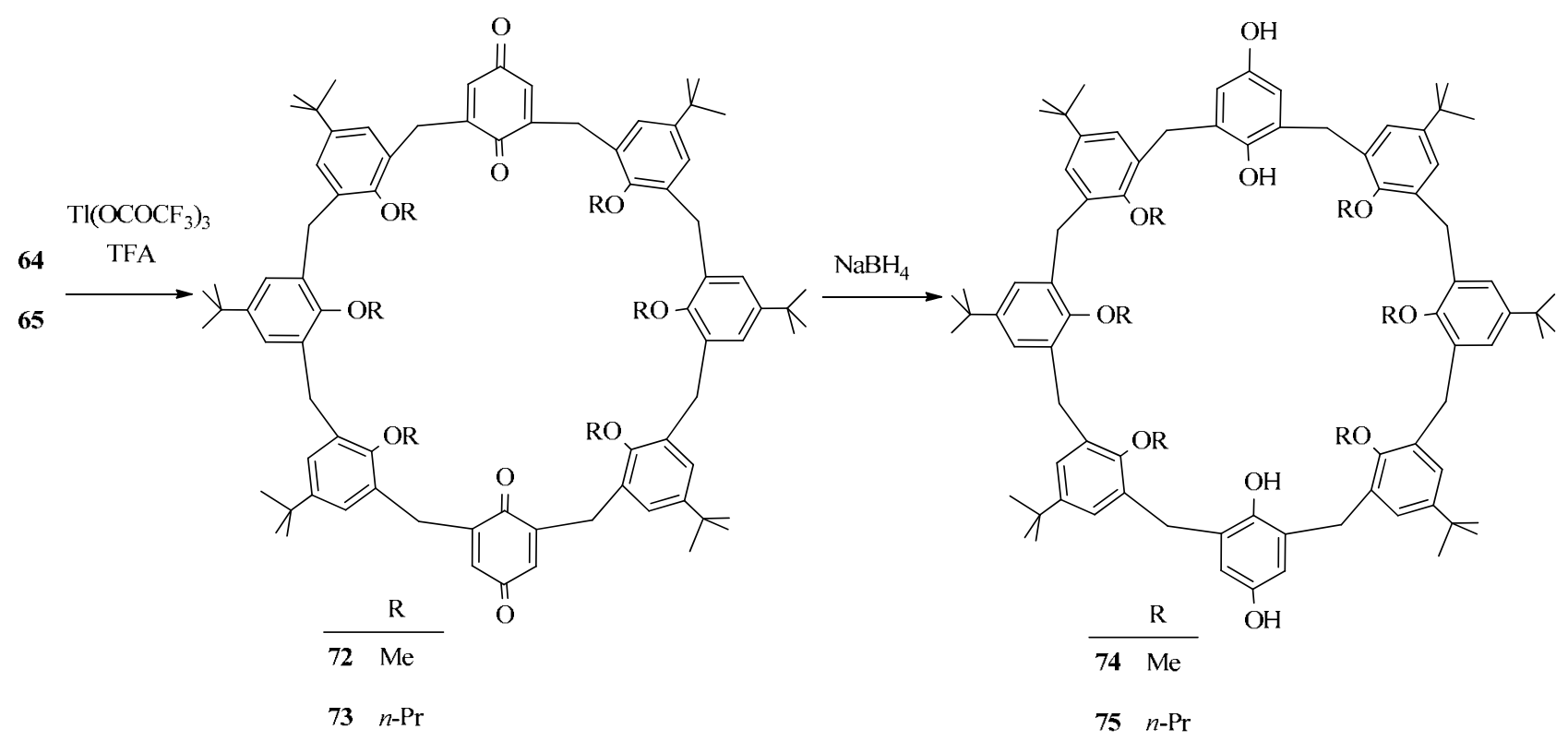

\section{Scheme 19}

The above methodology enables access to calix[8]arenes selectively substituted at the wide rim of aromatic rings 1 and 5 and as a result, calix[8]arenes containing nitro, amino, quinone and hydroquinone functionalities can be easily synthesized. ${ }^{95}$ 


\section{Functionalization of the narrow rim of calixarenes}

Some examples of functionalization of the calixarene narrow rim, selected from a large number of such processes, ${ }^{96-101}$ are presented. For the functionalization of calixarene narrow rim using Pdcatalyzed Sonogashira coupling reactions, the bis-triflate calixarene $\mathbf{7 6}$ and alkynes $\mathbf{7 7 a - d}$ have been employed. ${ }^{102}$ The reaction of $\mathbf{7 6}$ with trimethylsilylacetylene 77 a affords monoalkynylcalixarenes 78 and 79 along with derivatives 80 and $\mathbf{8 1}$, the formation of 79-81 containing iodine atoms, which were obtained via direct metal-assisted substitution by a halide was rather unexpected. It was also observed that calixarene 79 treated with phenylacetylene 77d yields dialkynylcalixarene $\mathbf{8 2}$.
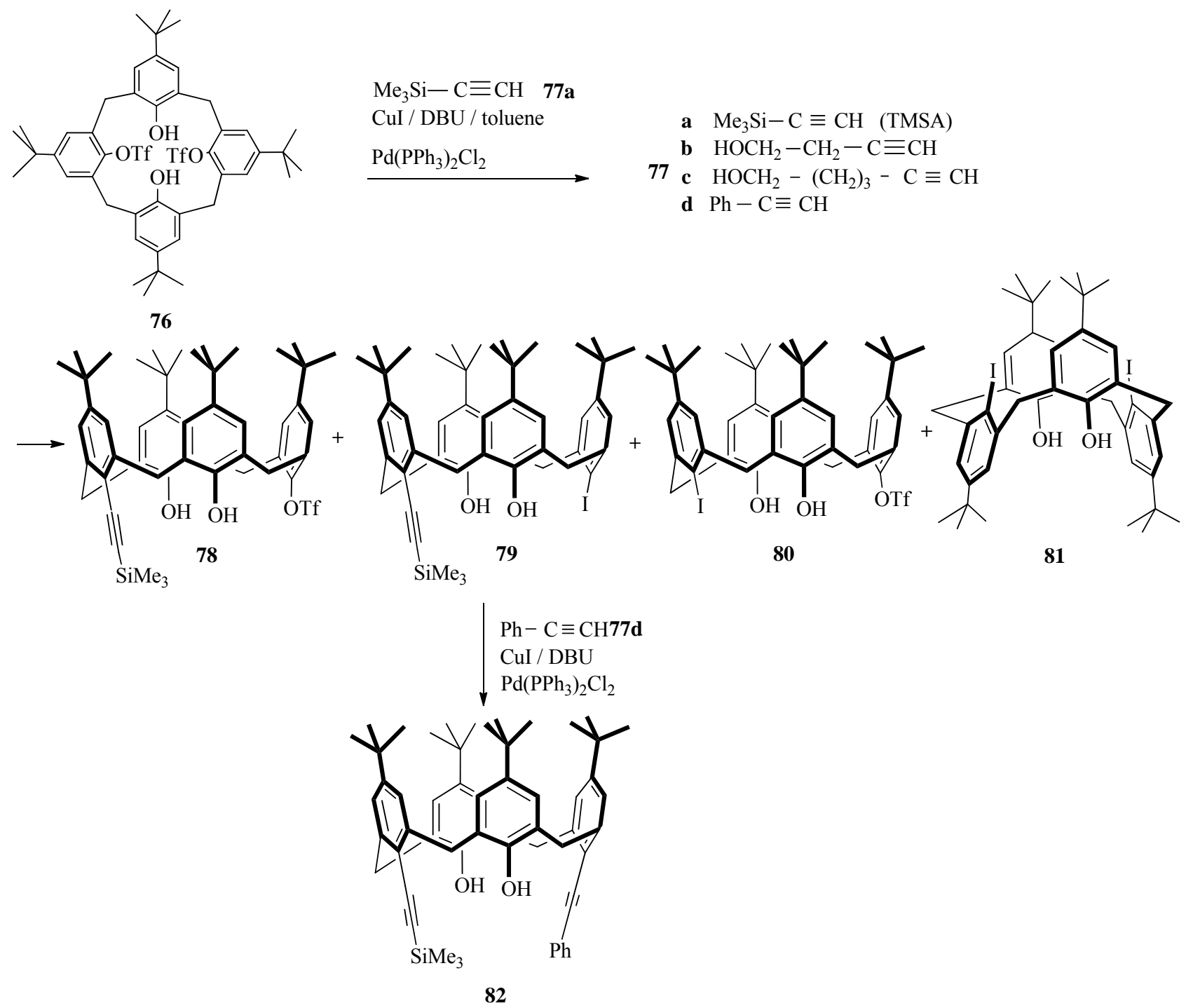

\section{Scheme 20}


Reactions of 76 with alkynes $77 \mathrm{~b}$ and $77 \mathrm{c}$ afforded monoalkynylcalixarenes 83 and 84, respectively, however the dialkynyl products were not formed. On the other hand, the reaction of $\mathbf{7 6}$ with 77d yielded both expected monoalkynyl and dialkynylcalixarenes 85 and 86, respectively.

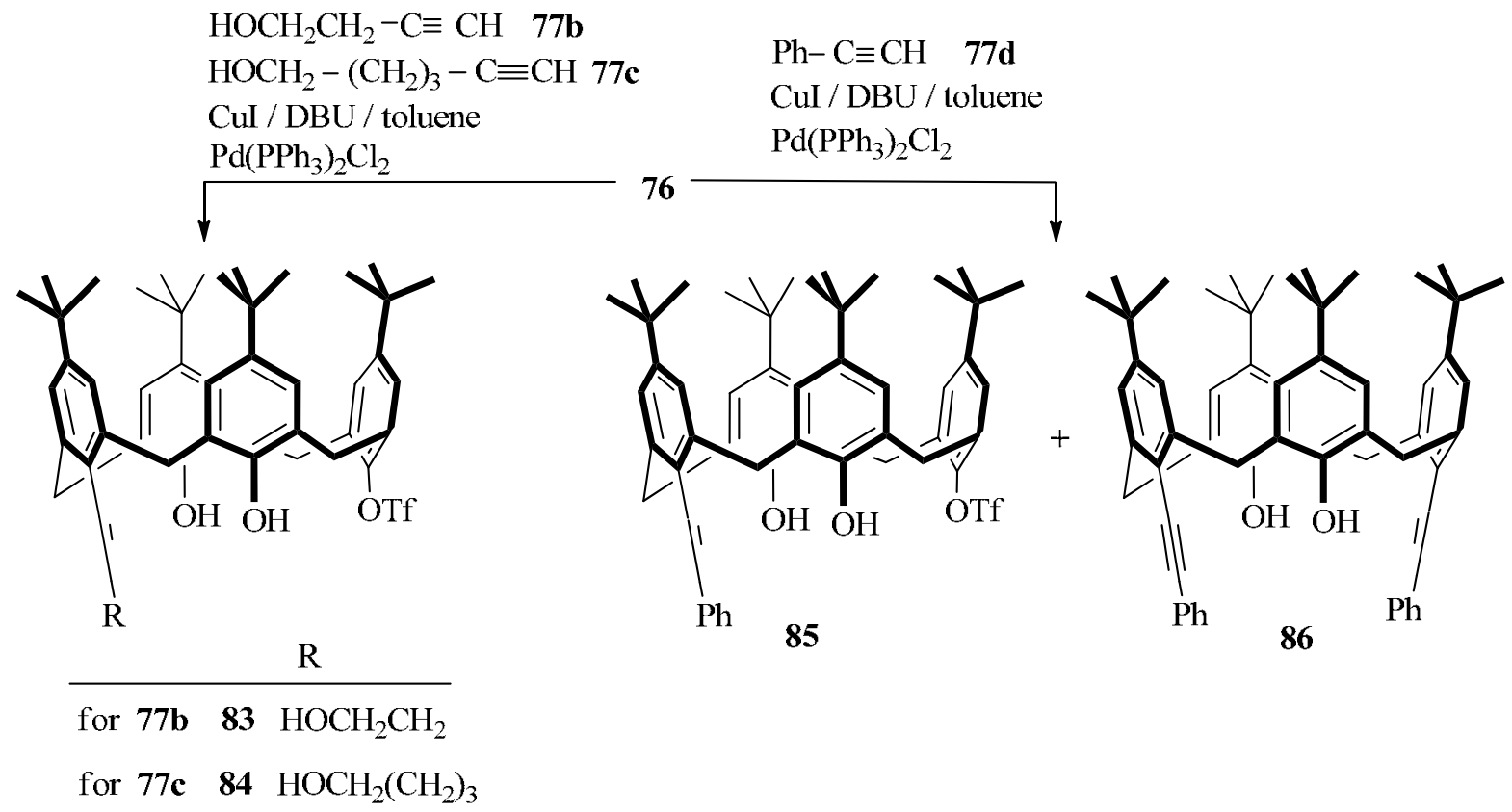

\section{Scheme21}

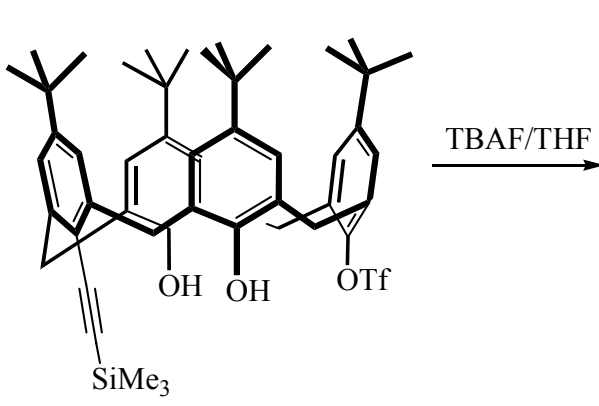

78

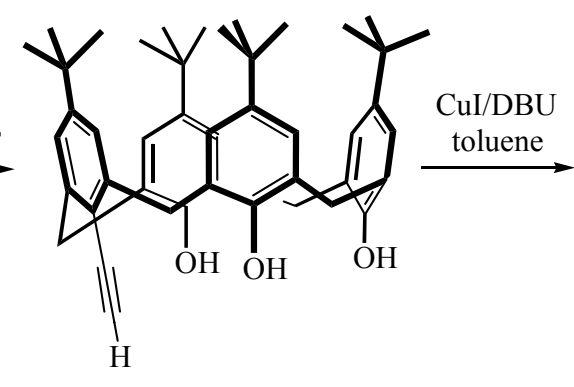

87

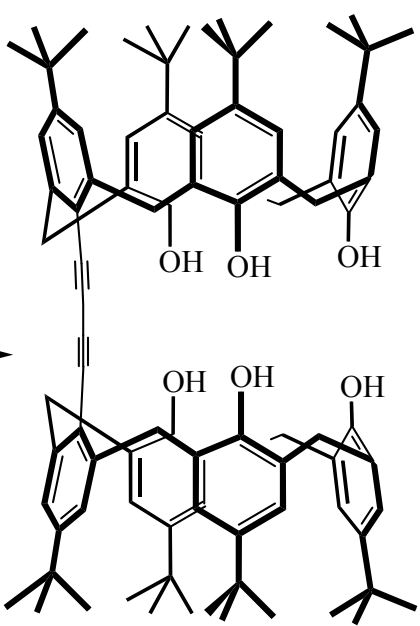

88

\section{Scheme 22}

The homocoupling of monoethynylcalixarene $\mathbf{8 7}$ leading to bis-calixarene $\mathbf{8 8}$ has also been achieved. For this purpose $\mathbf{7 8}$ was treated with tetrabutylammonium fluoride (TBAF) to remove the 
TMS group, the formed 87, upon reaction with $\mathrm{CuI}$ in the presence of $\mathrm{DBU}$, afforded the rigid narrow-rim-bridged bis-calixarene $\mathbf{8 8} .^{102}$

It is well-known that the narrow-rim $O$-alkylation of calix[4]arenes with alkyl halides proceeds favorably at the distal hydroxyl groups. This behavior results from a circular intramolecular hydrogen bonding in the monoalkylated intermediate and has been extensively studied.

However, the dialkylation at proximal hydroxyl groups, which is very important for the design of synthetic receptors, has been less intensively investigated. A convenient method for such syntheses is to "cap" two proximal hydroxyls with a disiloxane bridge as in 89. In these alkylation reactions, organohalides such as $\mathrm{BuI}$ or $\mathrm{BrCH}_{2} \mathrm{COOEt}$ were used and $t-\mathrm{BuOK}, \mathrm{K}_{2} \mathrm{CO}_{3}$ or $\mathrm{Cs}_{2} \mathrm{CO}_{3}$ served as bases. The reactions of capped 89 with the organohalides in the presence of a base afforded syn and anti products 90 and 91, respectively, which upon subsequent desilylation with TBAF, gave the corresponding syn and anti proximally-dialkylated products. The syn/anti ratio of these dialkylation products depends on the alkyl halide and the base used. Dialkylation of calixarene 89 in the presence of $t$-BuOK gives syn product exclusively, as did the use of $\mathrm{K}_{2} \mathrm{CO}_{3}$, however the use of $\mathrm{Cs}_{2} \mathrm{CO}_{3}$ strongly shifts the stereoselectivity toward the anti product. ${ }^{103}$

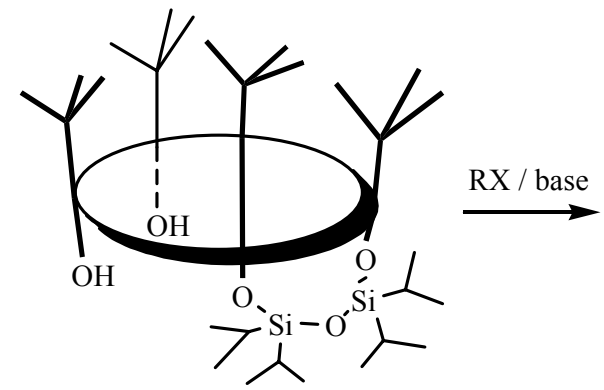

89

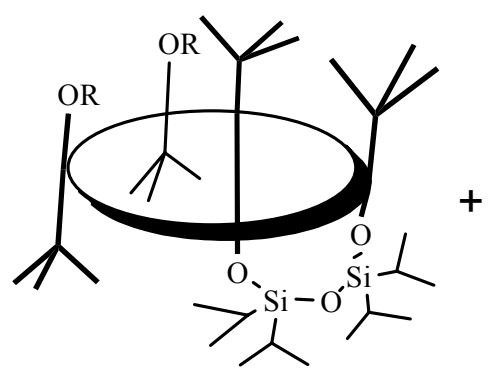

syn

90

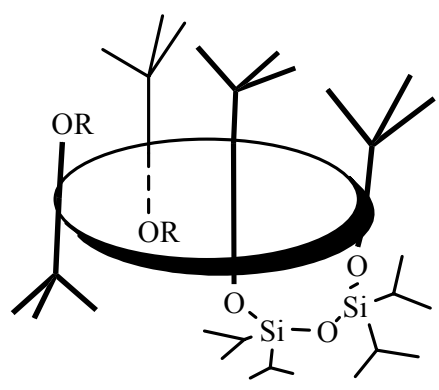

anti

91

\section{Scheme 23}

In the experiments the reaction of 92 with 1,3-dichloro-1,1,3,3-tetraisopropyldisiloxane in the presence of imidazole afforded disiloxane bridged 89. The treatment of 89 with the organohalides MeI, $\mathrm{BrCH}_{2} \mathrm{COOEt}$ or $\mathrm{PhCH}_{2} \mathrm{Br}$ yielded 1,2-alt 93 a-c which upon desilylation by TBAF gave $O, O^{\prime}$-dialkylated 1,2-alt calixarenes 94a-c. ${ }^{104}$

However, it was found that the treatment of $\mathbf{8 9}$ with methyl iodide under changed conditions may give monomethylated product 95. The reaction of the remaining hydroxyl group of 95 with benzyl bromide completed the alkylation yielding 1,2-alt 96 which upon deprotection with TBAF afforded 1,2-alt 97. It is noteworthy that compounds of the type of $\mathbf{9 6}$ and $\mathbf{9 7}$ are inherently chiral due to the presence of two differently substituted adjacent aromatic rings. ${ }^{104}$ All of these reactions proceeded smoothly and with excellent yields 


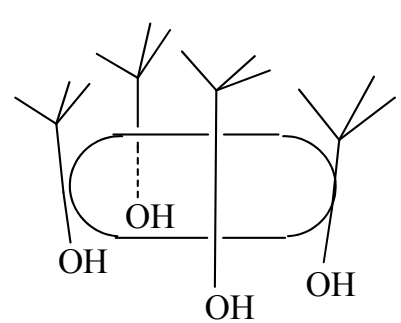

92
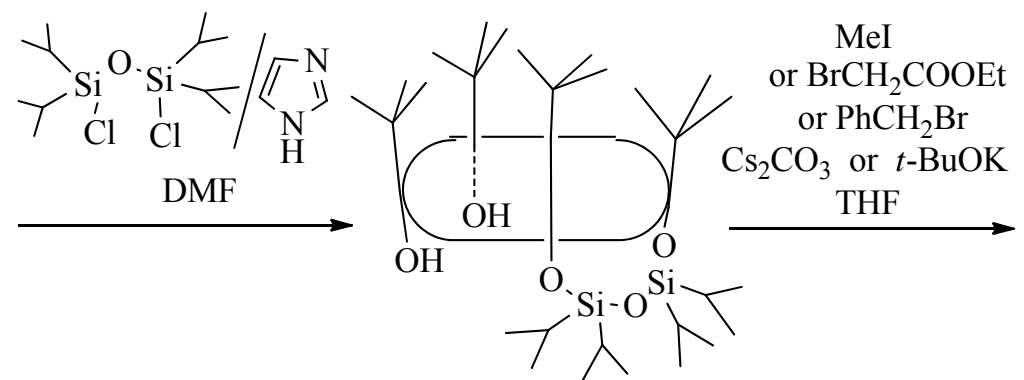

89

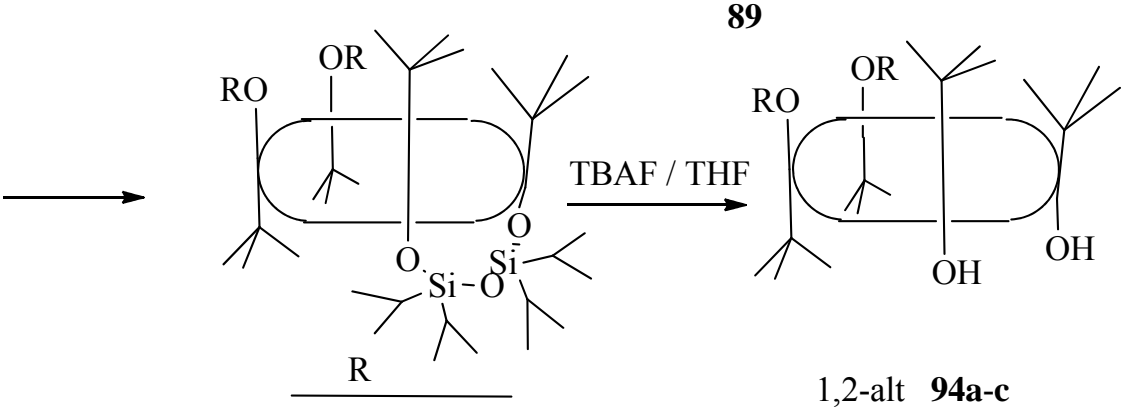

a $\mathrm{Me}$

$\begin{array}{rll}\text { 1,2-alt } 93 & \text { b } & \mathrm{CH}_{2} \mathrm{COOEt} \\ & \text { c } & \mathrm{CH}_{2} \mathrm{Ph}\end{array}$

\section{Scheme 24}

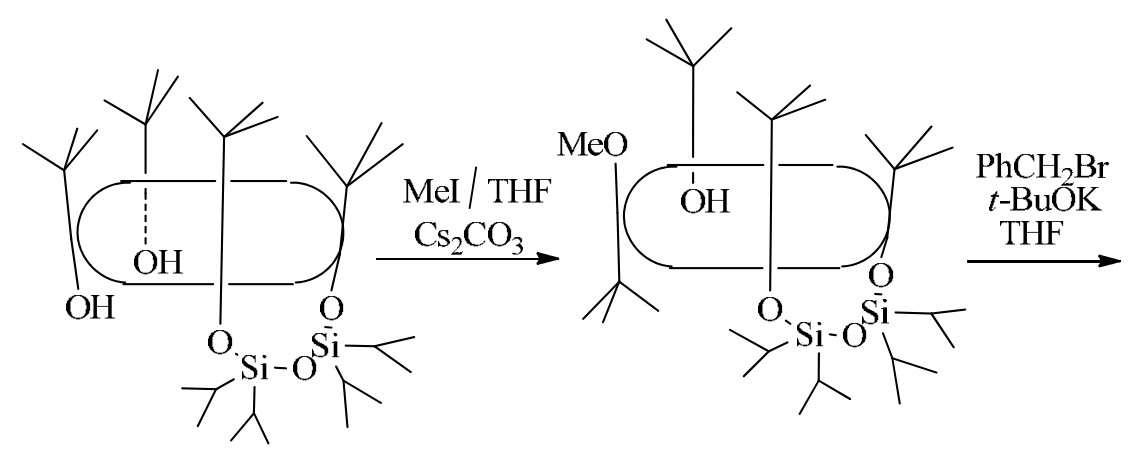

89

95

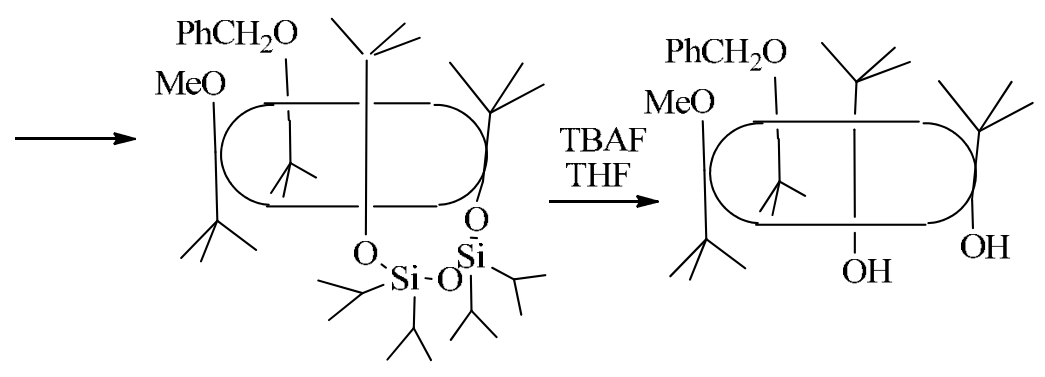

96

97

Scheme 25 
In recent years, fluorescent molecular sensors for the detection of environmentally important heavy metals, such as copper, ${ }^{105,106}$ and mercury, ${ }^{107,108}$ have received increasing interest. To this aim, calixarenes 98-103 bearing attached dansyl groups have been synthesised and investigated for their use as fluorescent sensors for metal ions. ${ }^{109}$ Their syntheses involve the treatment of the appropriate calixarenes with dansyl chloride and sodium hydride, in THF. In this way calixarenes 104-106 were converted into 98-100, respectively.

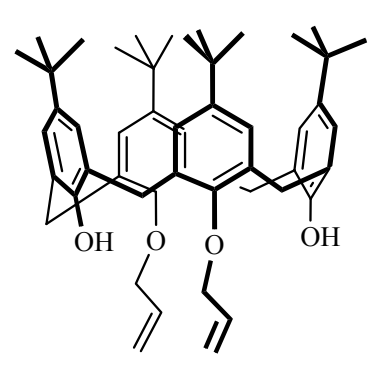

104

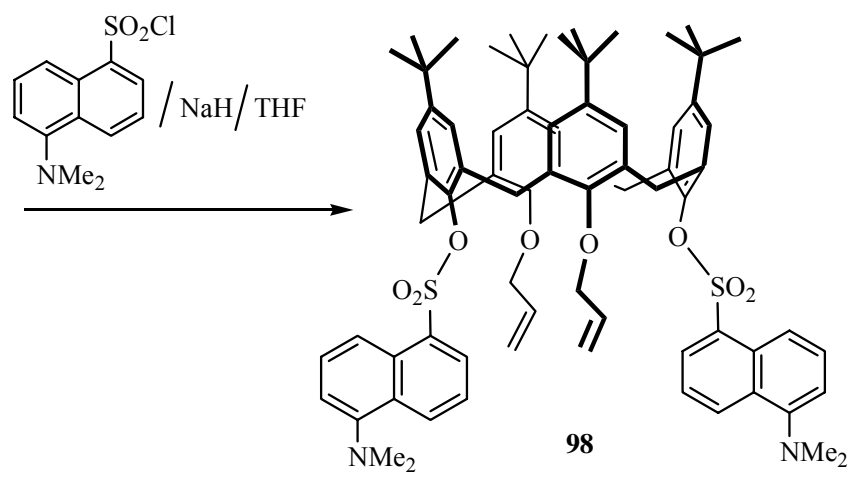

\section{Scheme 26}

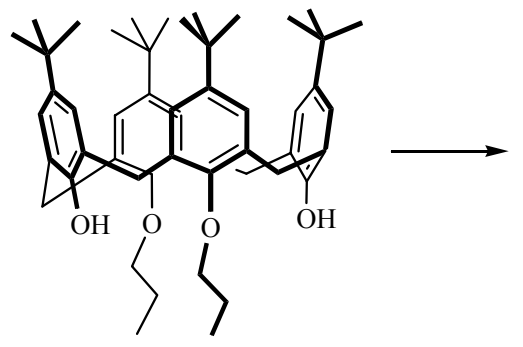

105

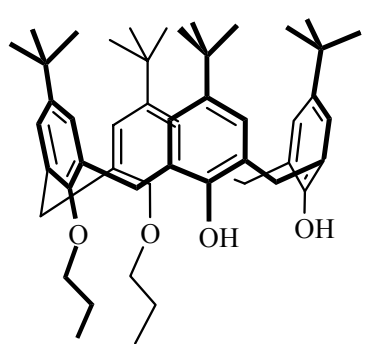

106

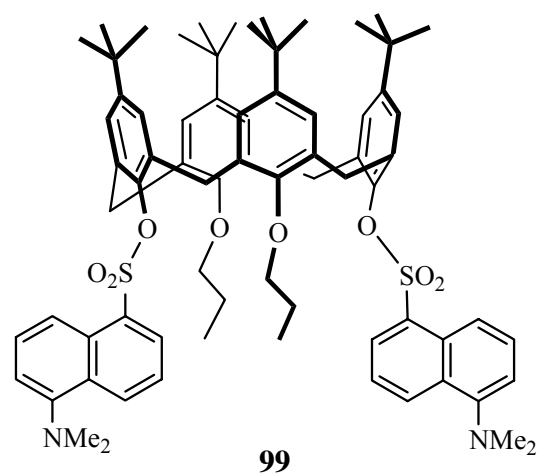

99

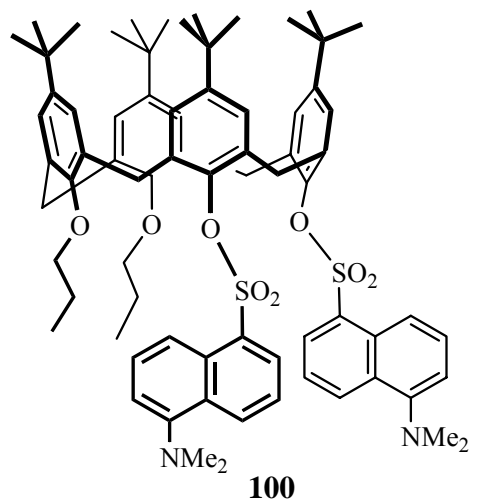

\section{Scheme 27}


Similar reaction of calixarene 107 affords the mixture of cone 101a and paco 101b, which could be separated by column chromatography. Using the same procedure, calixarenes 108 and 109 yielded 102 and 103, respectively.

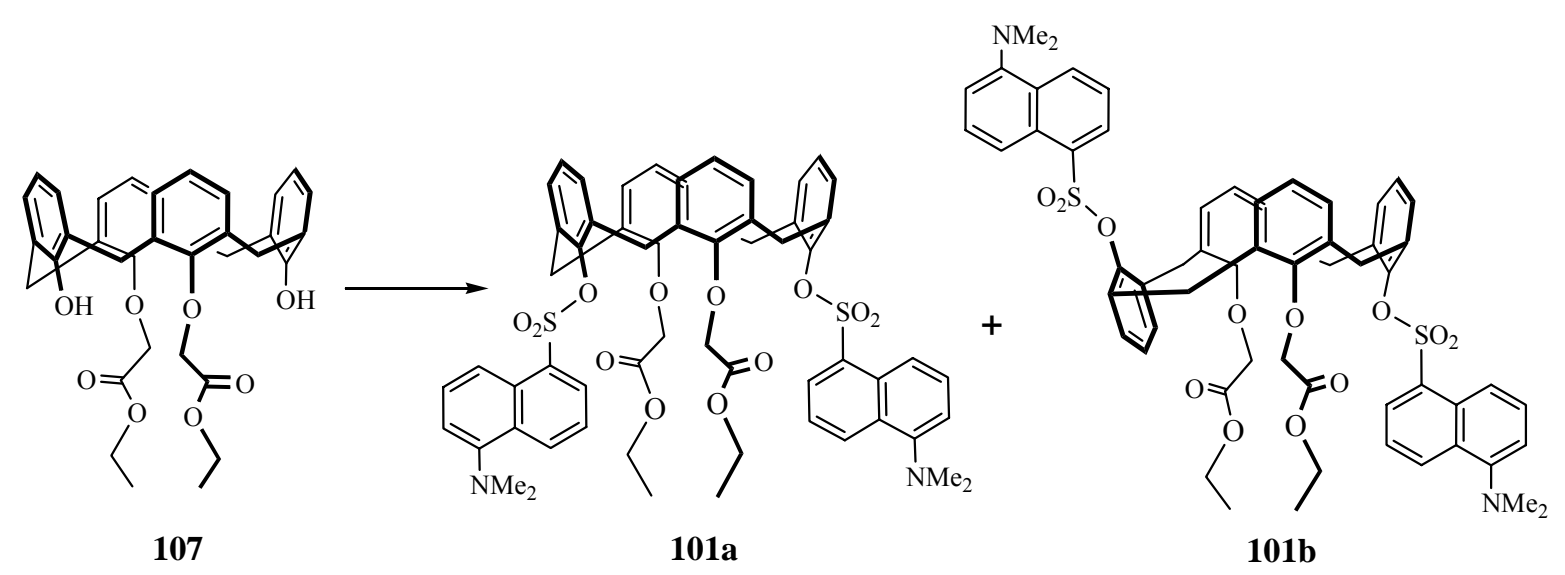

Scheme 28

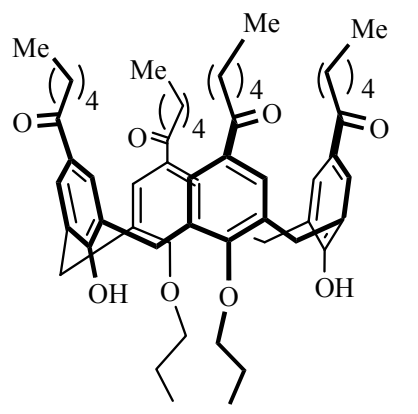

108

\section{Scheme 29}

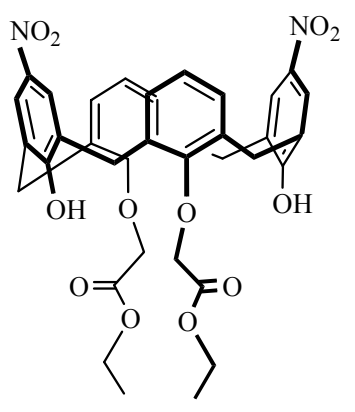

109
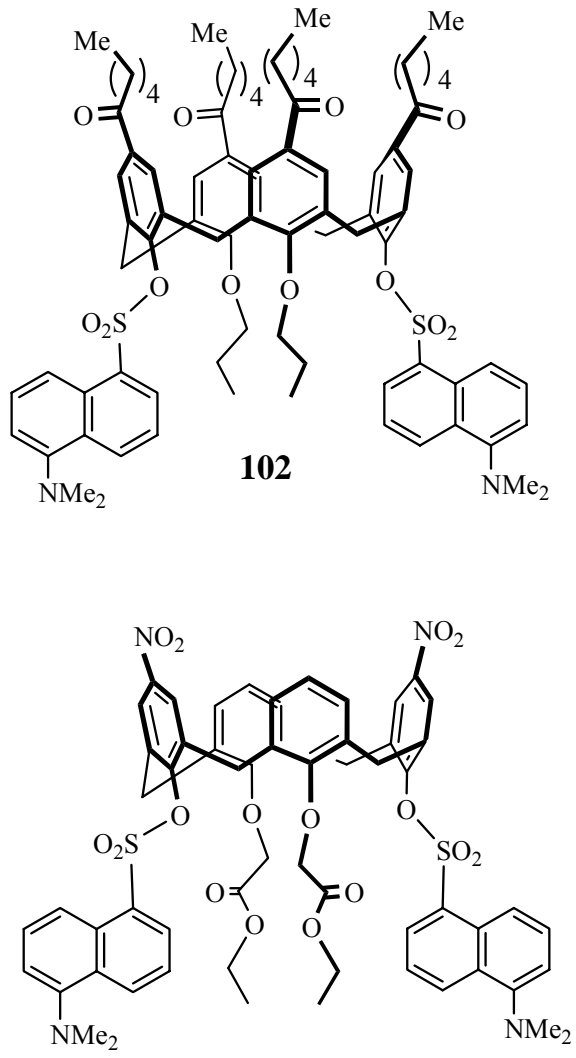

103
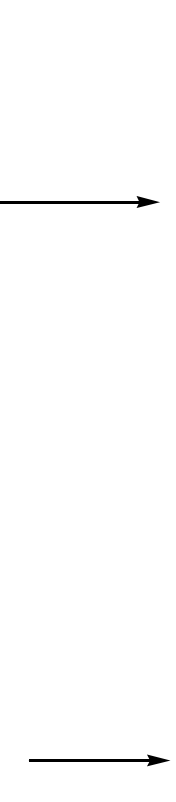
The crystal structures of dansylated calixarenes, namely the unsolvated 101b, and two solvated species $\mathbf{9 8} \cdot \mathrm{CH}_{2}(\mathrm{OH}) \mathrm{CN}$ and $\mathbf{9 9} \cdot 3 \mathrm{CH}_{3} \mathrm{CN}$ have been described, in the crystal structure of $\mathbf{1 0 1 b}$, the calixarene is in a paco conformation, while in the solvates of $\mathbf{9 8}$ and $\mathbf{9 9}$ the calixarenes are fixed in cone conformations. Fluorescence measurements have shown that calixarenes 98-102 selectively recognize $\mathrm{Cu}^{2+}$ ions; moreover, $101 \mathrm{a}$ may be used for simultaneous determination of $\mathrm{Cu}^{2+}$ and $\mathrm{Hg}^{2+}$ ions. $^{109}$

The direct alkylation of calixarene 92 with substituted benzaldehydes 110a,b has been reported. The reaction of 92 with 110a affords the mono-and dialdehydes 111a and 112a, respectively. However, in the case of $\mathbf{1 1 0 b}$ the dialdehyde $\mathbf{1 1 2 b}$ was obtained as the sole product. ${ }^{110}$

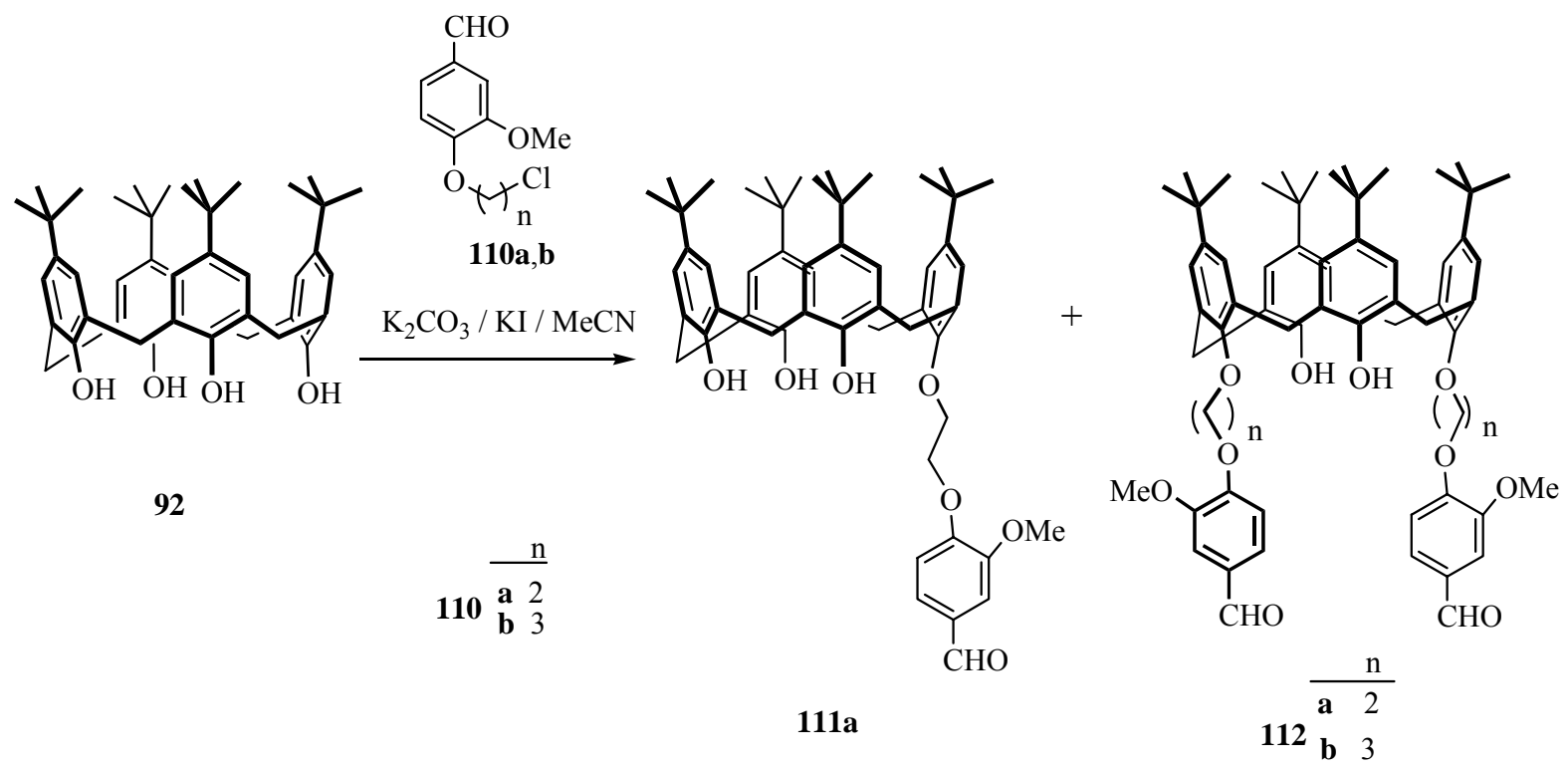

\section{Scheme 30}

The introduction of aldehyde groups into calixarenes can enable further functionalization reactions. Thus, the condensation of 111a and 112a,b with $S$-methyl-and $S$-benzyl-dithiocarbazates affords the sulfur-containing Schiff bases, from 111a two products 113a,b were obtained, while the reaction of 112a,b yielded four products 114a-d. ${ }^{110}$ It is noteworthy that syntheses of monofunctionalized calixarenes, ${ }^{111}$ such as 111a and 113a,b are not as common as those leading to fully functionalized species. 

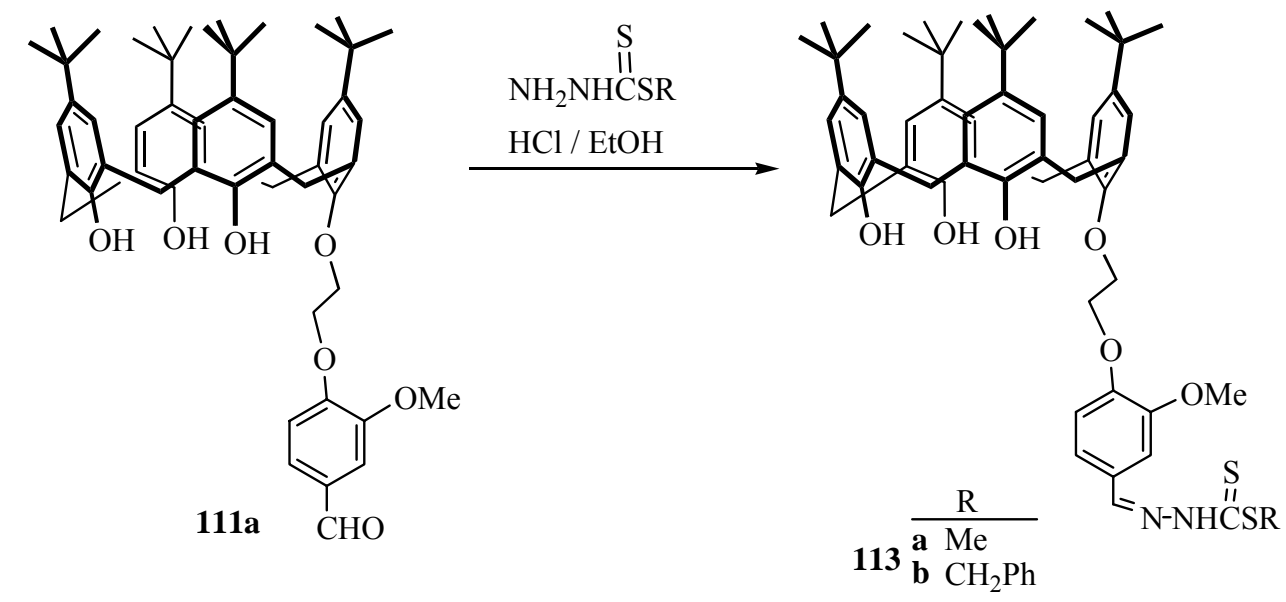

\section{Scheme 31}
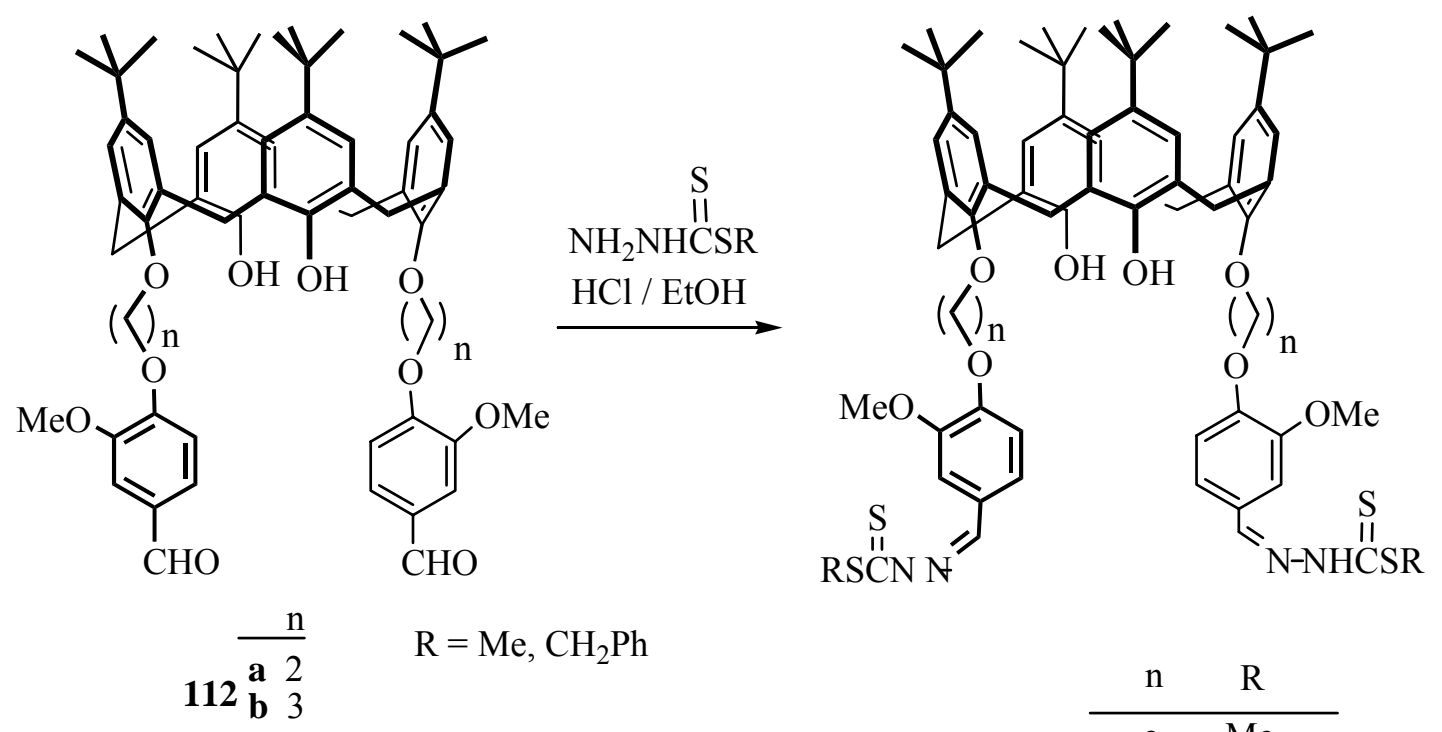

112 a 2

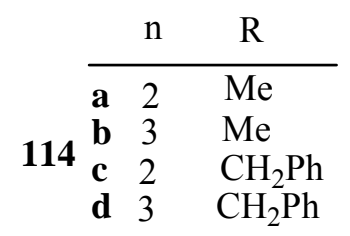

\section{Scheme 32}

In order to investigate the reactivity of the aldehyde groups of calixarene 115, it was submitted to reactions with hydrazine hydrate and with diaminomaleonitrile affording 116 and 117, with salicylaldehyde hydrazone and 2-pyridinaldehyde hydrazone, compounds 118 and 119 were formed, respectively. ${ }^{112}$ All reactions proceed at room temperature, the ${ }^{1} \mathrm{H}$ NMR data indicate that the products are in cone conformations. In all cases it was found that the pendant arms of the compounds do not adopt a face-to-face structure but are bent away from each other. 


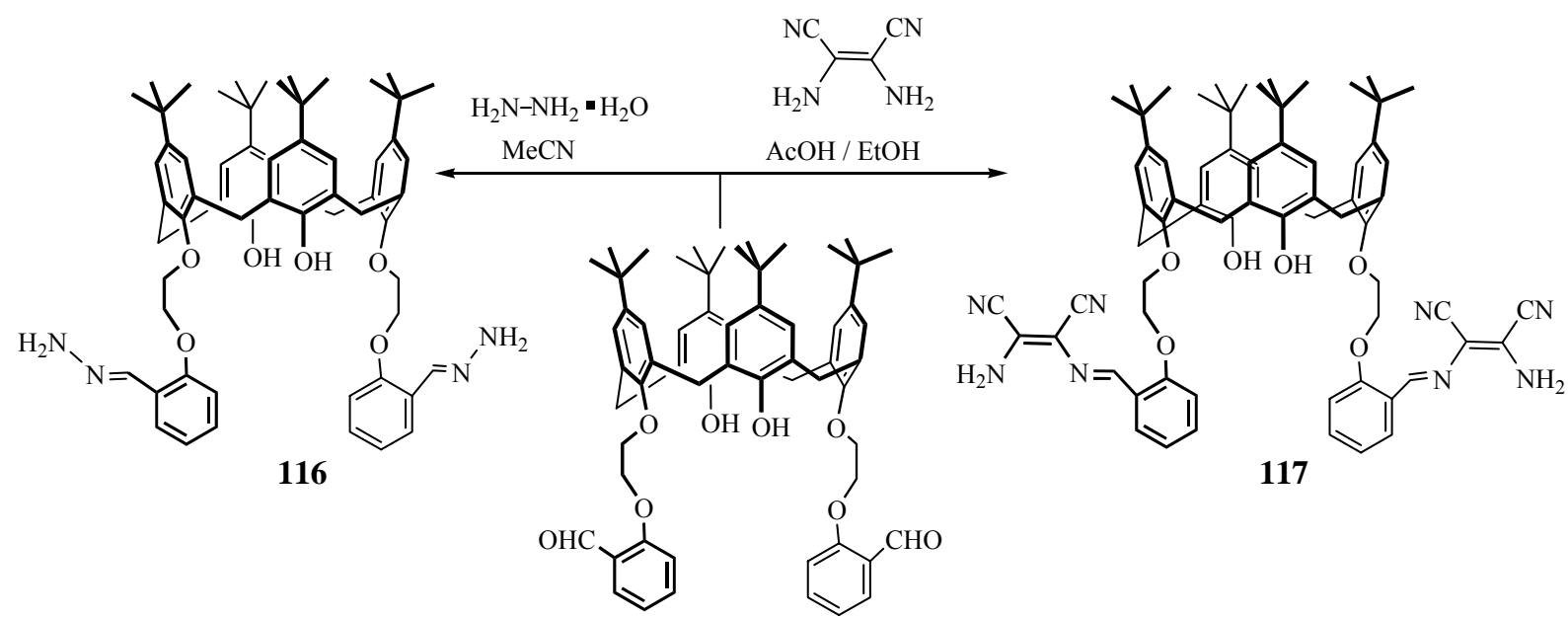

115

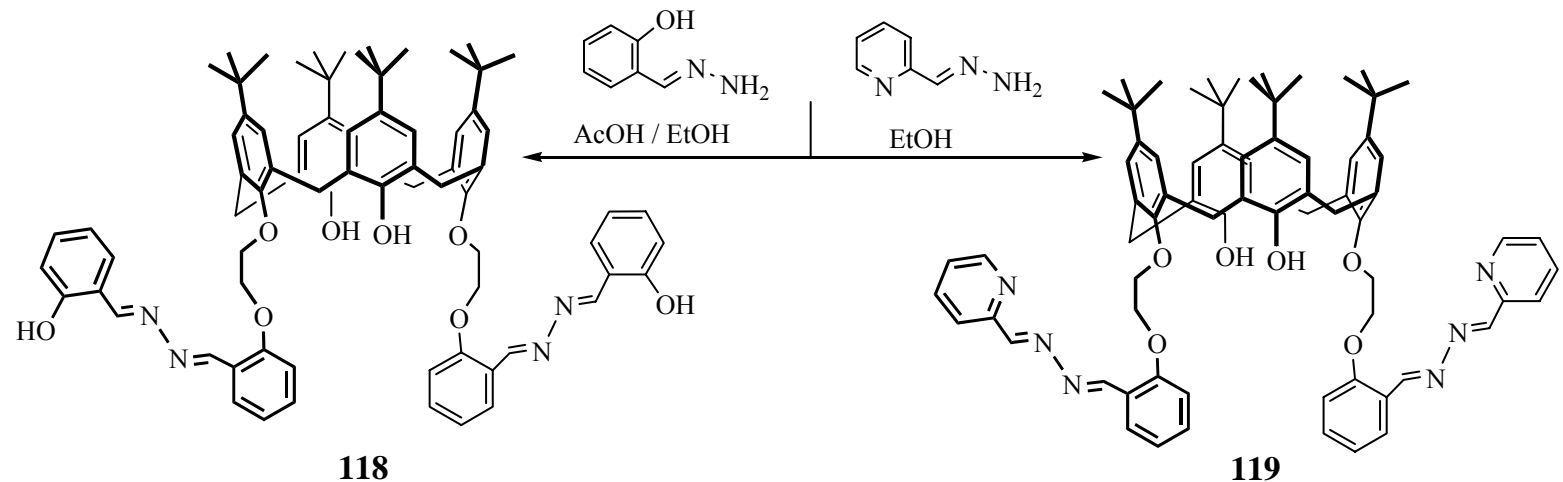

\section{Scheme 33}

For a study using calixarenes as receptors for the colorimetric detection of fluoride ions, ${ }^{113}$ compounds 120-123 were synthesized. It should be noted that due to its high electronegativity and small size, fluoride ion can form strong hydrogen bonds at low concentrations, and is a sufficiently strong base to promote deprotonation at higher concentrations. The synthesis of the receptors commenced with the treatment of calixarene 124 with $p$-hydroxybenzaldehyde and $p$ hydroxyacetophenone, leading to $125 \mathrm{a}$ and $125 \mathrm{~b}$, respectively. Reaction of $125 \mathrm{a}$ with $p$ nitrophenylhydrazine and 2,4-dinitrophenylhydrazine affords calixarenes 120 and 121, while 125b with the same reagents yields 122 and 123. ${ }^{114}$

It was found that 120 selectively recognizes $\mathrm{F}^{-}$ions; among $\mathrm{H}_{2} \mathrm{PO}_{4}^{-}, \mathrm{AcO}^{-}$and $\mathrm{F}^{-}$ions, the solution color changes from yellow to purple only with $\mathrm{F}^{-}$ions, whereas with 121 the color also changes with $\mathrm{H}_{2} \mathrm{PO}_{4}{ }^{-}$and $\mathrm{AcO}^{-}$ions. The observation that the limiting value in the absorption maximum of 120 was achieved at four $\mathrm{F}^{-}$equivalents instead of only two equivalents was unexpected. This behavior is explained by the fact that addition of one $\mathrm{F}^{-}$equivalent results in the hydrogen bonding with the NH protons in 120 and formation of a 1:1 complex, $120 \bullet \mathrm{F}^{-}$. Upon addition of a second $\mathrm{F}^{-}$equivalent, the complex $120 \cdot 2 \mathrm{~F}^{-}$is formed, and further addition of $\mathrm{F}^{-}$ 
equivalents causes deprotonation of the NH groups. The above studies are promising for further design of colorimetric sensors of fluoride ions. ${ }^{114}$
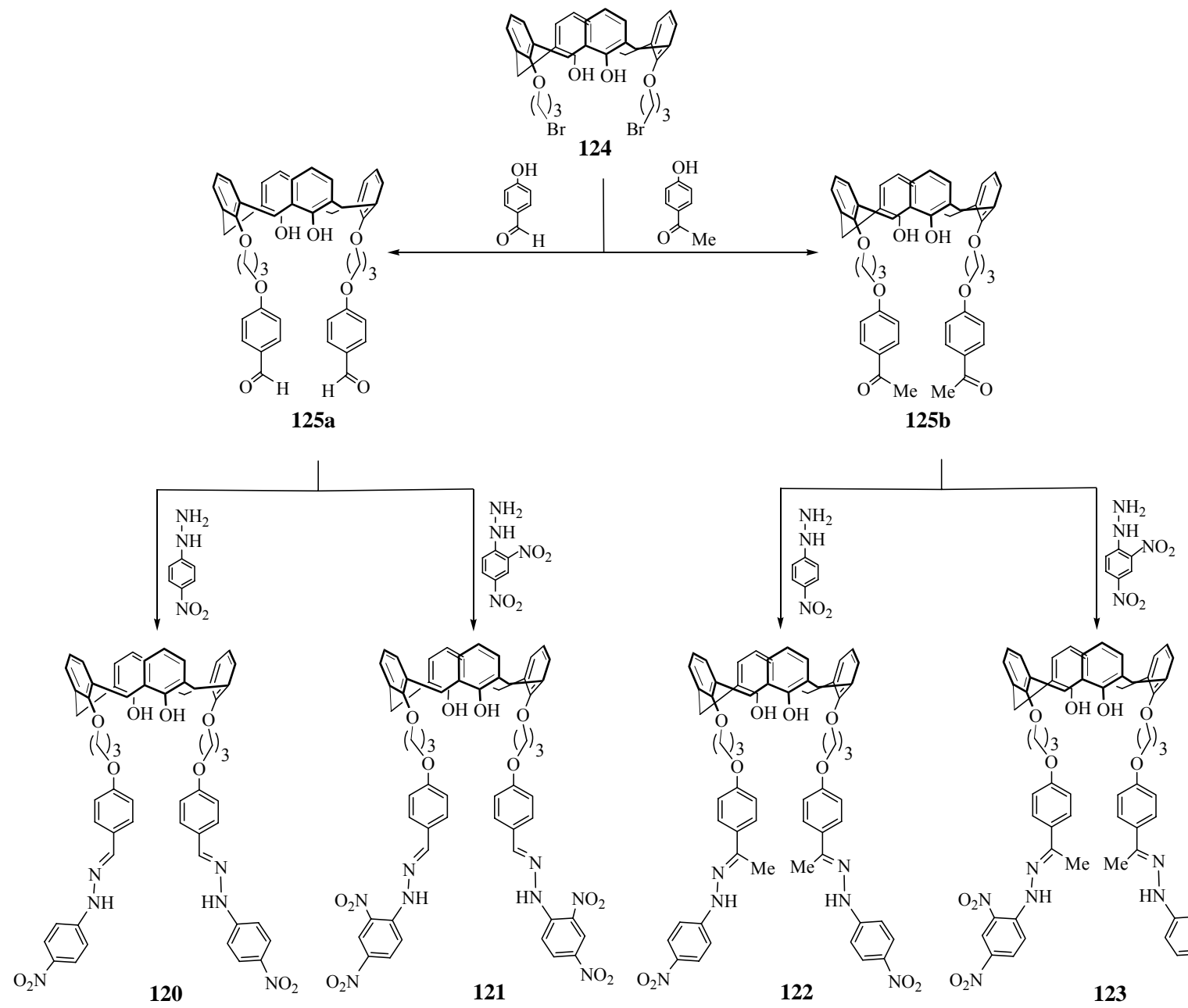

122

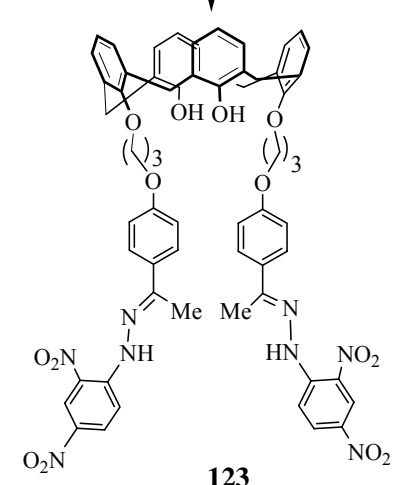

\section{Scheme 34}

In a study of calixarenes containing tethered drug moieties, calixarene 126 substituted by nalidixic acid, a quinolone antibiotic, has been synthesized; for this purpose calixarene 92 was treated with bromopropyl ester of nalidixic acid $127 .{ }^{115}$ 


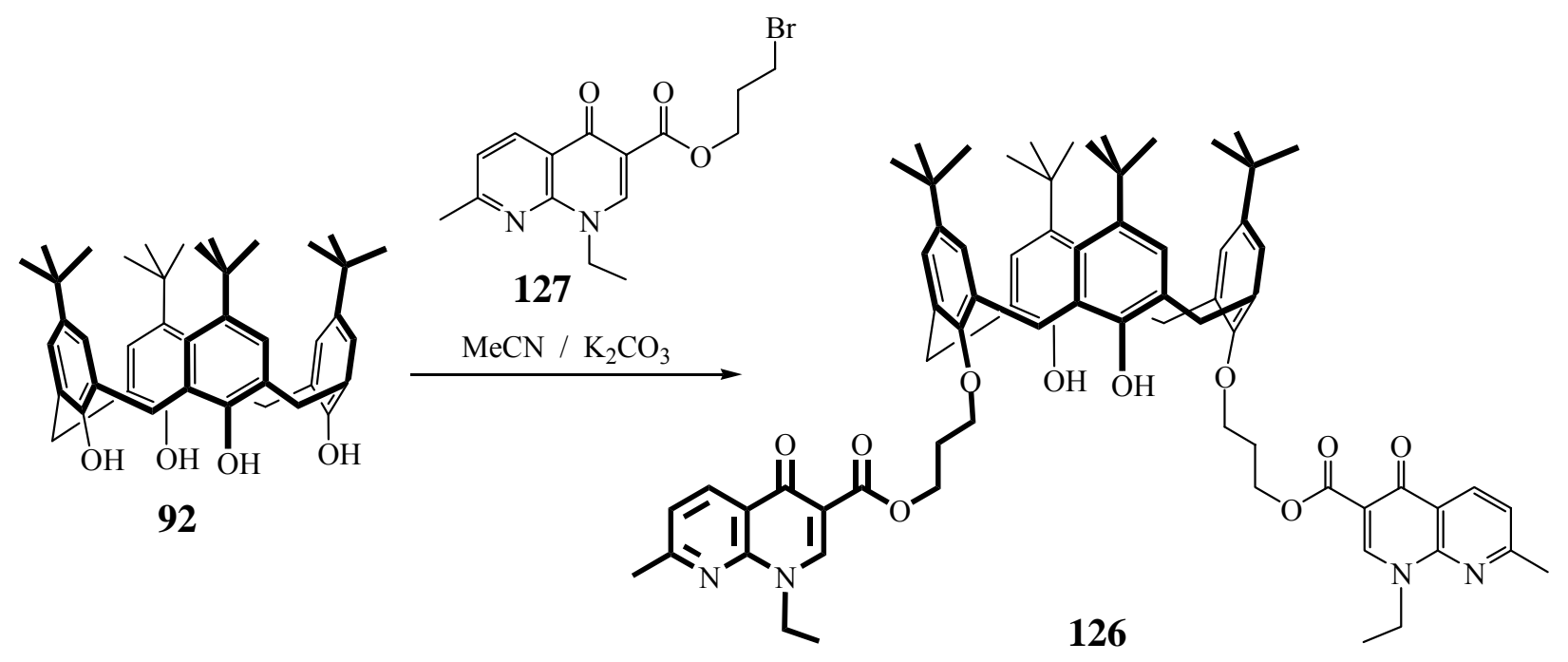

\section{Scheme 35}

All six possible conformational isomers of the proximally para-disubstituted calixarene 128 were selectively synthesized and isolated; they are one cone, two paco, two 1,2-alt and one 1,3-alt conformers. It was established that the two paco $\mathbf{1 2 8 b}^{*}$ and $\mathbf{1 2 8}^{*}$, one 1,2 -alt $\mathbf{1 2 8} \mathbf{e}^{*}$ and one 1,3 -alt 128f* ${ }^{*}$ conformers are inherently chiral. ${ }^{116}$

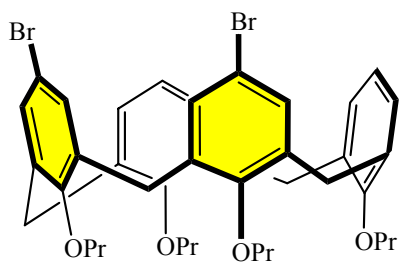

128a

cone

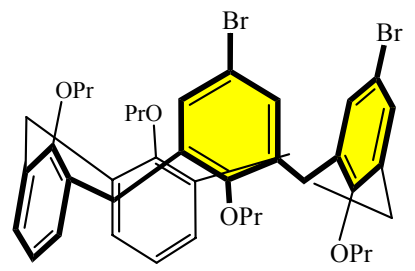

128d

$1,2-$ alt

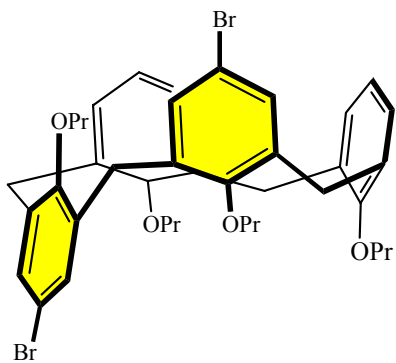

$128 b^{*}$

paco

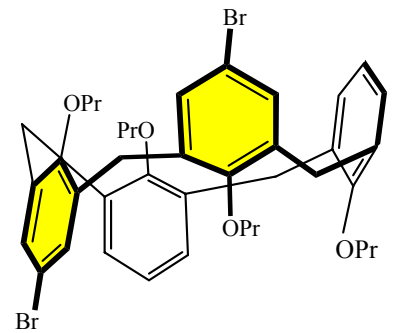

$128 \mathrm{e}^{*}$

1,2-alt

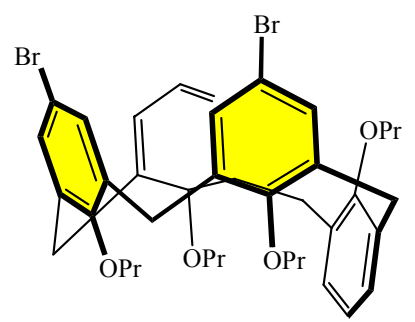

$128 c^{*}$

paco

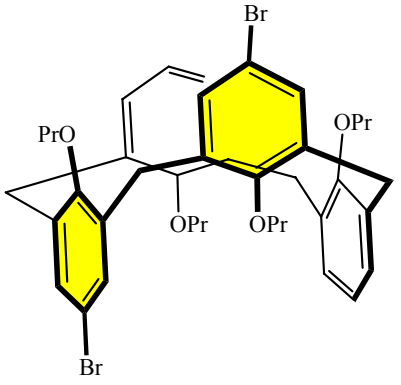

$128 f$ *

1,3 -alt

(in the structures of 128a-f the disubstituted rings are darkened)

\section{Scheme 36}


The above compounds were synthesized by propylation of calixarenes $129,130,131 *$ and $132 *$ in the presence of a base. The role of the base in this process is very important: e.g. for 129 the use of $\mathrm{NaH}$ leads preferentially to cone 128a, whereas in the presence of $\mathrm{Cs}_{2} \mathrm{CO}_{3}$ and $t$-BuOK, conformers paco 128b* and 1,2-alt 128d, respectively, are obtained.

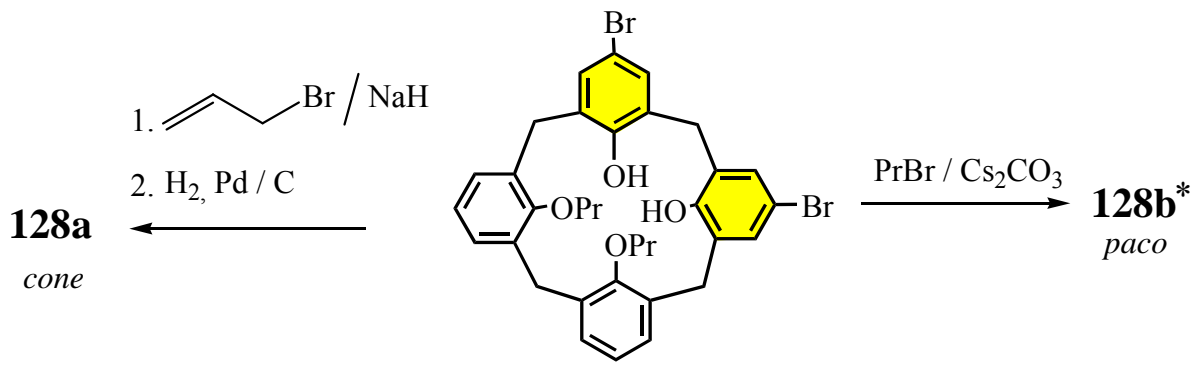

129

$\mathrm{PrBr} / t \mathrm{BuOK}$

\section{8d}

1,2-alt

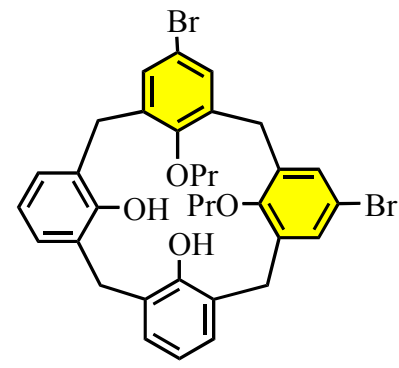

130

$\downarrow \operatorname{PrBr} / \mathrm{Cs}_{2} \mathrm{CO}_{3}$

128c*

paco

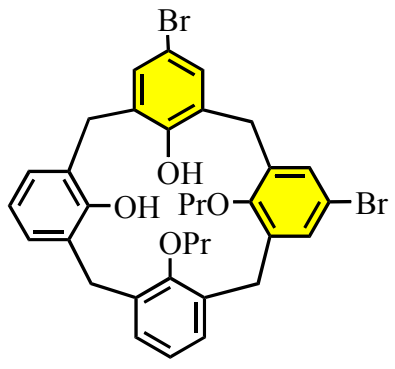

131*

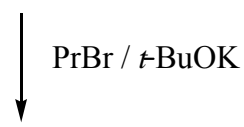

$128 \mathrm{e}^{*}$

1,2-alt

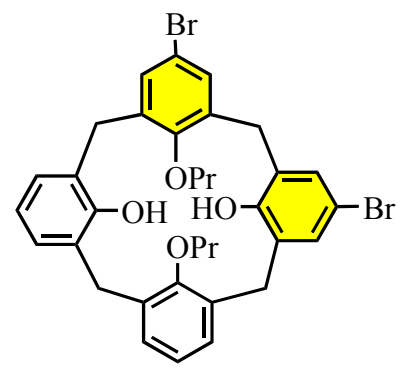

132*

$\mathrm{PrBr} / \mathrm{Cs}_{2} \mathrm{CO}_{3}$

$128 f$ *

1,3-alt

\section{Scheme 37}

Calixarenes 128b* $\mathbf{1 2 8}^{*}, \mathbf{1 2 8}^{*}$ and 128f* are promising precursors for the design of synthetic receptors capable of chiral discrimination, since bromine atoms may be readily replaced by other substituents.

The tannin-like calixarene 133a, bearing two gallate units was synthesized along with calixarenes 133b and 133c. ${ }^{117}$ Gallic acid is present in the plant tannin in form of condensed 
compounds, e.g. with glucose or quinic acid, tannins have biological properties and are able to bind proteins and metal ions.

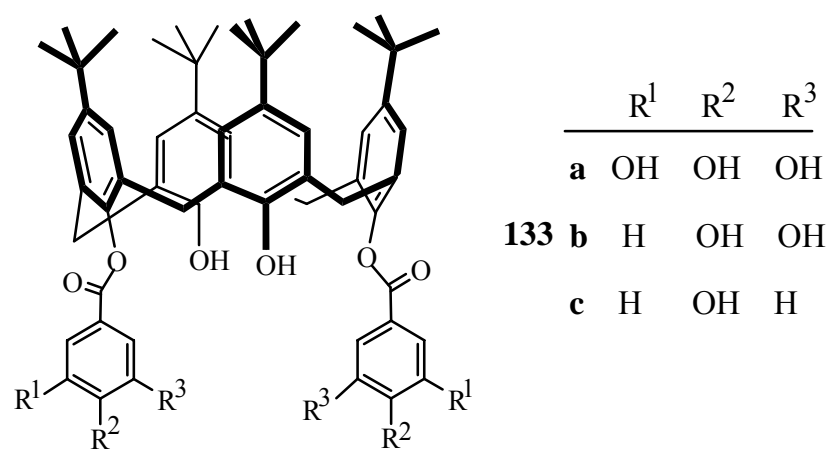

\section{Scheme 38}

The synthesis of 133a begins with the reaction of calixarene 92 with 3,4,5-triacetoxybenzoyl chloride affording 134 which, upon deacetylation with hydrazine monohydrate, yields the desired product. Calixarenes 133b and 133c were obtained by a similar procedure.

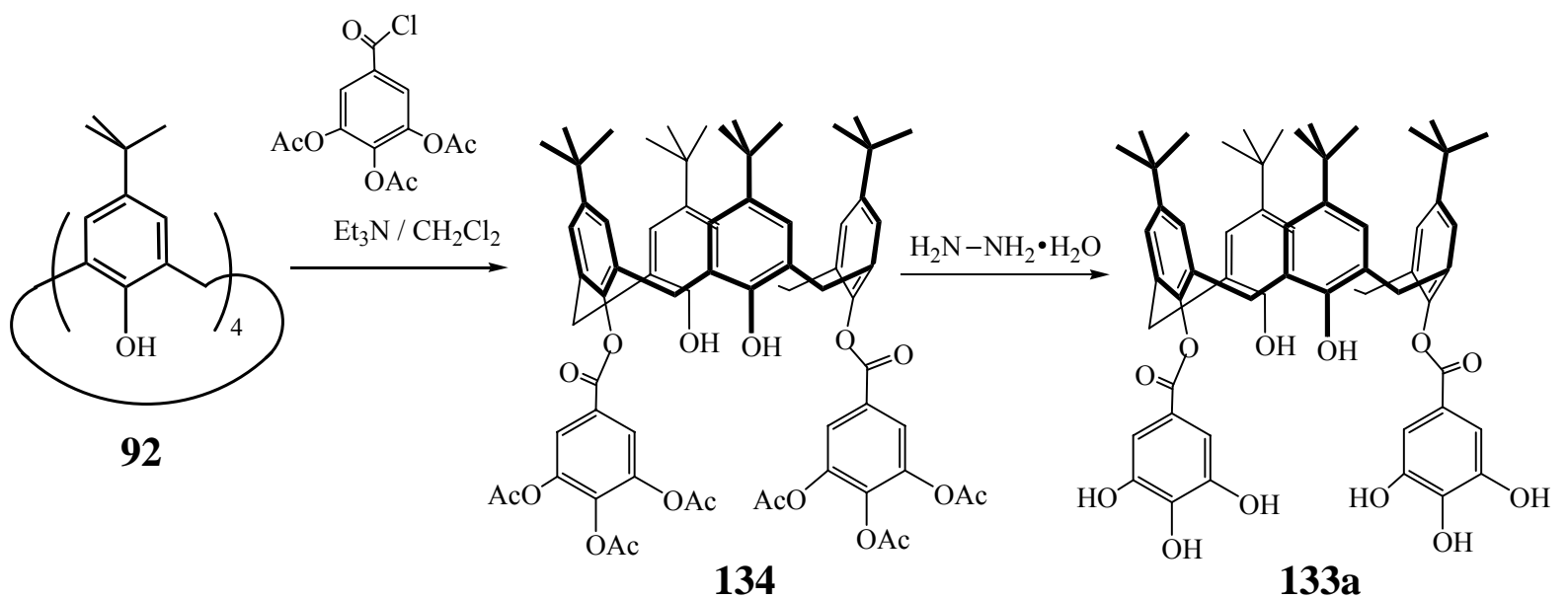

\section{Scheme 39}

The ${ }^{1} \mathrm{H}$ NMR spectra show that calixarenes 133a-c are in cone conformations and have $C_{2}$ symmetry. The galloyl groups in 133a are situated near to each other, allowing an unusual nonbonding close contact, the $\mathrm{OH}-\pi$ interaction between the hydroxyl group and the aromatic ring of the galloyl unit is therefore possible.

The reactions of easily-accessible calixarene phosphoric esters 135-138 with bromotrimethylsilane, followed by methanol, have been reported to yield water soluble calixarene phosphoric acids 139-142. ${ }^{11}$ 


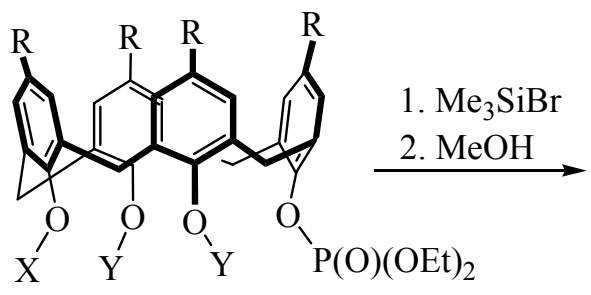

135 - 138

\begin{tabular}{clcc} 
& $\mathrm{R}$ & $\mathrm{X}$ & $\mathrm{Y}$ \\
\hline $\mathbf{1 3 5}$ & $\mathrm{H}$ & $\mathrm{Et}$ & $\mathrm{H}$ \\
$\mathbf{1 3 6}$ & $\mathrm{H}$ & $\mathrm{P}(\mathrm{O})(\mathrm{OEt})_{2}$ & $\mathrm{H}$ \\
$\mathbf{1 3 7}$ & $t-\mathrm{Bu}$ & $\mathrm{P}(\mathrm{O})(\mathrm{OEt})_{2}$ & $\mathrm{H}$ \\
$\mathbf{1 3 8}$ & $t-\mathrm{Bu}$ & $\mathrm{P}(\mathrm{O})(\mathrm{OEt})_{2}$ & $\mathrm{P}(\mathrm{O})(\mathrm{OEt})_{2}$
\end{tabular}

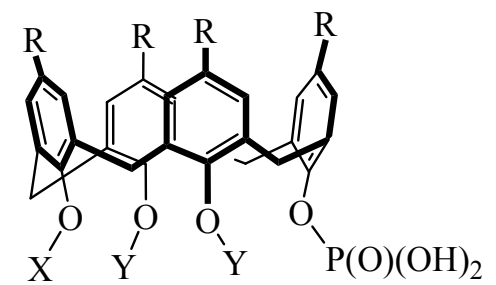

139 - 142

\begin{tabular}{clcc} 
& $\mathrm{R}$ & $\mathrm{X}$ & $\mathrm{Y}$ \\
\hline $\mathbf{1 3 9}$ & $\mathrm{H}$ & $\mathrm{Et}$ & $\mathrm{H}$ \\
$\mathbf{1 4 0}$ & $\mathrm{H}$ & $\mathrm{P}(\mathrm{O})(\mathrm{OH})_{2}$ & $\mathrm{H}$ \\
$\mathbf{1 4 1}$ & $t-\mathrm{Bu}$ & $\mathrm{P}(\mathrm{O})(\mathrm{OH})_{2}$ & $\mathrm{H}$ \\
$\mathbf{1 4 2}$ & $t-\mathrm{Bu}$ & $\mathrm{P}(\mathrm{O})(\mathrm{OH})_{2}$ & $\mathrm{P}(\mathrm{O})(\mathrm{OH})_{2}$
\end{tabular}

\section{Scheme 40}

The reactions of chiral calixarene 143, leading to inherently chiral calixarenes 144-146 have also been reported. ${ }^{118}$ These begin with the acylation of 143 by benzoyl chloride affording calixarene 144, bromination of 143 and 144 with NBS yields calixarenes 145 and 146, respectively. Calixarenes 143-146 react with bromotrimethylsilane forming trimethylsilyl esters 147-150 which, without isolation, were treated with methanol to give inherently chiral calixarene phosphoric acids 151-154, formed as racemic mixtures of two enantiomers, similarly to 143-146.
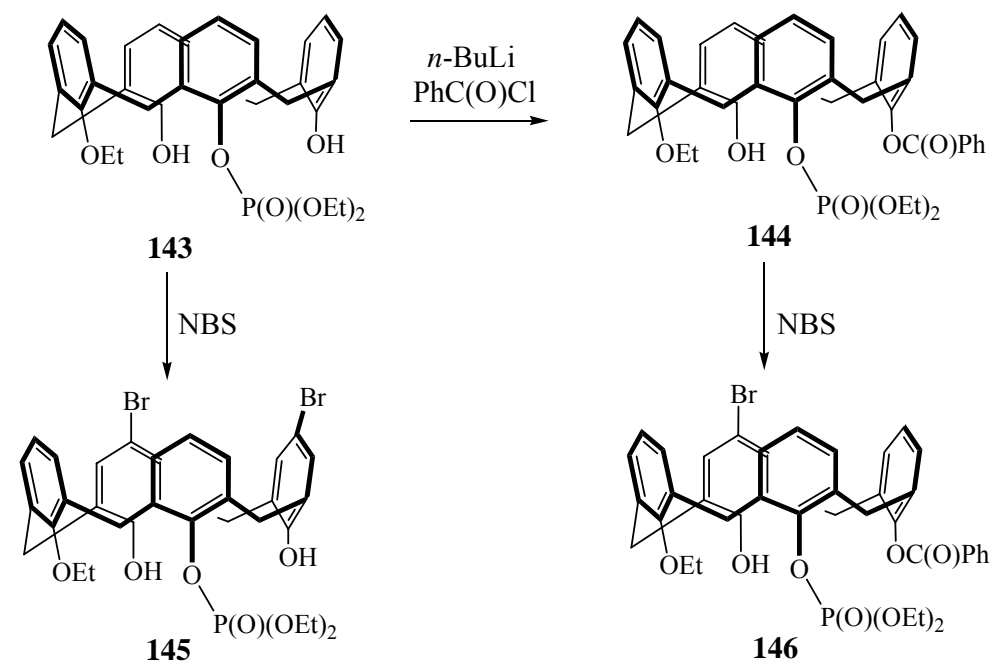

\section{Scheme 41}



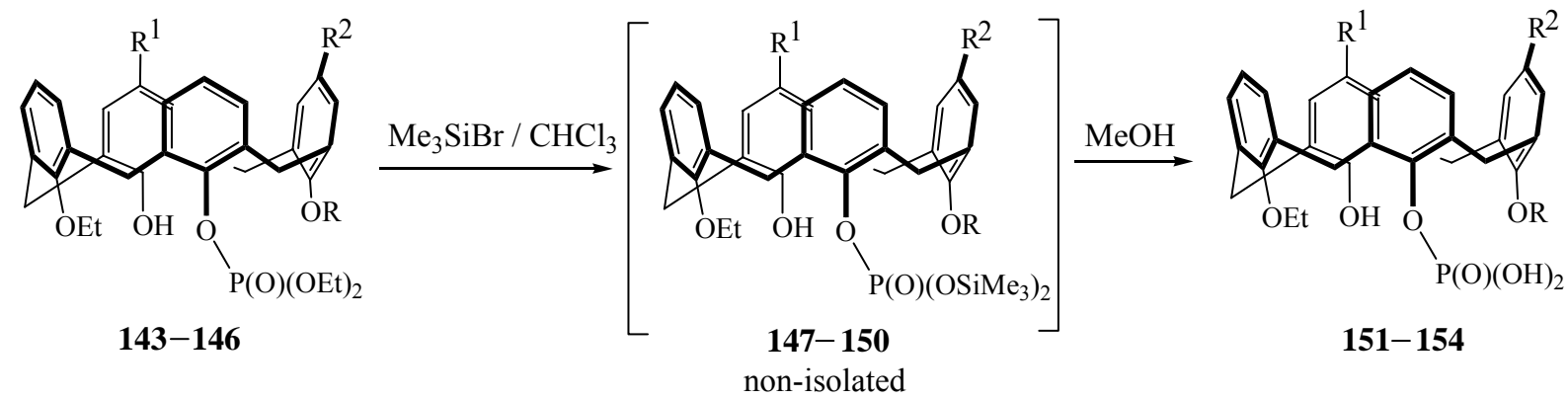

\begin{tabular}{llllll} 
& & & $\mathrm{R}$ & $\mathrm{R}^{1}$ & $\mathrm{R}^{2}$ \\
\hline 143 & 147 & 151 & $\mathrm{H}$ & $\mathrm{H}$ & $\mathrm{H}$ \\
144 & 148 & 152 & $\mathrm{C}(\mathrm{O}) \mathrm{Ph}$ & $\mathrm{H}$ & $\mathrm{H}$ \\
145 & 149 & 153 & $\mathrm{H}$ & $\mathrm{Br}$ & $\mathrm{Br}$ \\
146 & 150 & 154 & $\mathrm{C}(\mathrm{O}) \mathrm{Ph}$ & $\mathrm{Br}$ & $\mathrm{H}$
\end{tabular}

\section{Scheme 42}

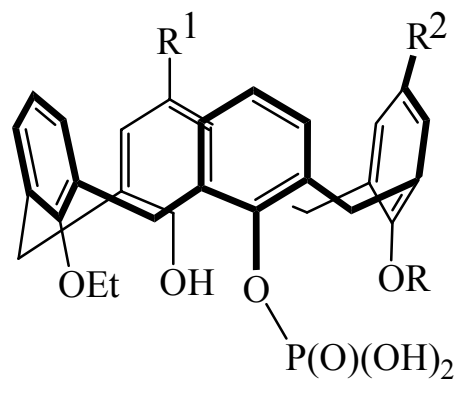

$151-154$<smiles>C[C@H](N)c1ccccc1</smiles>

$155-158$

\begin{tabular}{ccccc} 
& & $\mathrm{R}$ & $\mathrm{R}^{1}$ & $\mathrm{R}^{2}$ \\
\hline 151 & 155 & $\mathrm{H}$ & $\mathrm{H}$ & $\mathrm{H}$ \\
152 & 156 & $\mathrm{C}(\mathrm{O}) \mathrm{Ph}$ & $\mathrm{H}$ & $\mathrm{H}$ \\
153 & 157 & $\mathrm{H}$ & $\mathrm{Br}$ & $\mathrm{Br}$ \\
154 & 158 & $\mathrm{C}(\mathrm{O}) \mathrm{Ph}$ & $\mathrm{Br}$ & $\mathrm{H}$
\end{tabular}

\section{Scheme 43}

Reactions of 151-154 with L-(-)- $\alpha$-phenylethylamine (PEA) afford weakly dissociated diastereomeric salts 155-158, respectively, which could be easily separated into diastereomers by RP HPLC on Separon SGX C18 or Partisil 5 ODS 3 achiral columns. Other chiral amines may also be used besides L-PEA. ${ }^{118}$

Due to their conformational flexibility the chemistry of large calix $[n]$ arenes $(n=6,8)$ has been less investigated than that of calix[4]arenes. It should be pointed out that large calixarenes have 
some advantages since they may serve as receptors for bulky guest molecules and as enzyme mimics. Considering the many applications of calixarenes, as well as the potentially valuable properties of calix $[n]$ arenes $(n=6,8)$, synthetic methods for preparation of water-soluble large calixarenes functionalized at the narrow rim have been reported, ${ }^{119}$ using calixarenes 159-161 as starting materials.

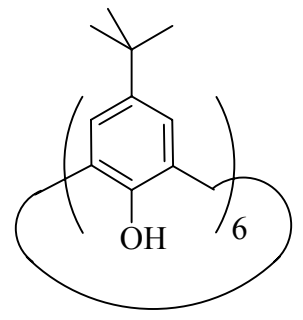

159

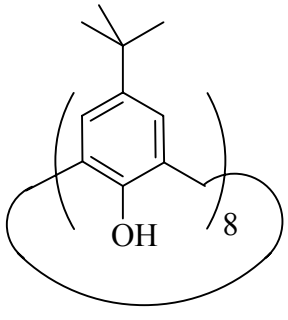

160

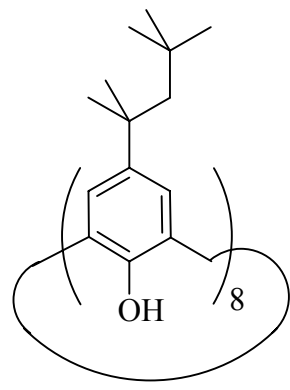

161

\section{Scheme 44}

Two types of reagents were chosen: bromoalkanenitriles and oligo(ethylene glycol) derivatives, in both cases, calixarenes which can be further functionalized are obtained. Moreover, the reactions with oligo(ethylene glycol) derivatives afford hydrophillic calixarenes. A simple synthetic procedure involves the use of 4-bromobutyronitrile, 7-bromoheptanenitrile as well as activated tri, hexa-and dodeca(ethylene glycol) derivatives.

In reactions with bromoalkanenitriles the full alkylation of 159-161 performed with bromobutyronitrile in the presence of $\mathrm{K}_{2} \mathrm{CO}_{3}$ yielded 162-164, and reaction of 160 with bromoheptanenitrile yielded 165.

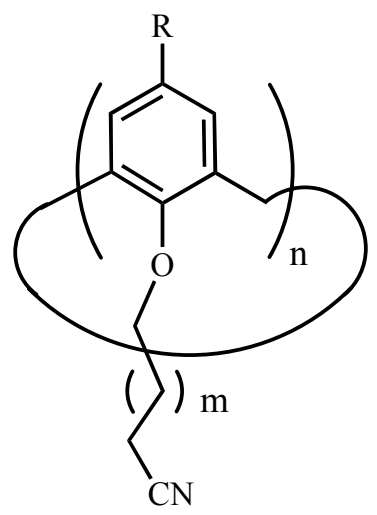

\section{Scheme 45}

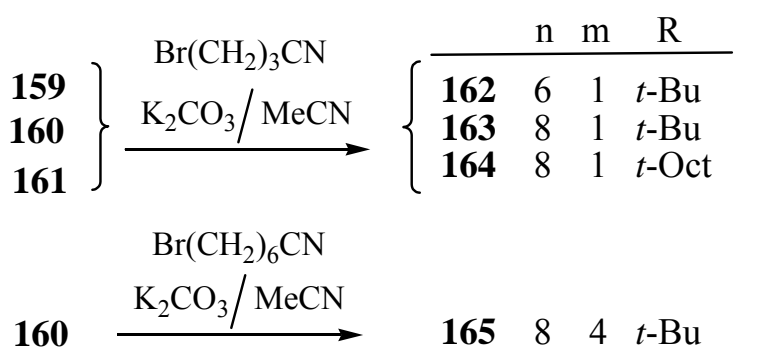


In reactions with oligo(ethylene glycol) derivatives, the monoalkylation of $\mathbf{1 6 0}$ with 3,6,9trioxadecyl mesylate, carried out in the presence of sodium hydride afforded 166.
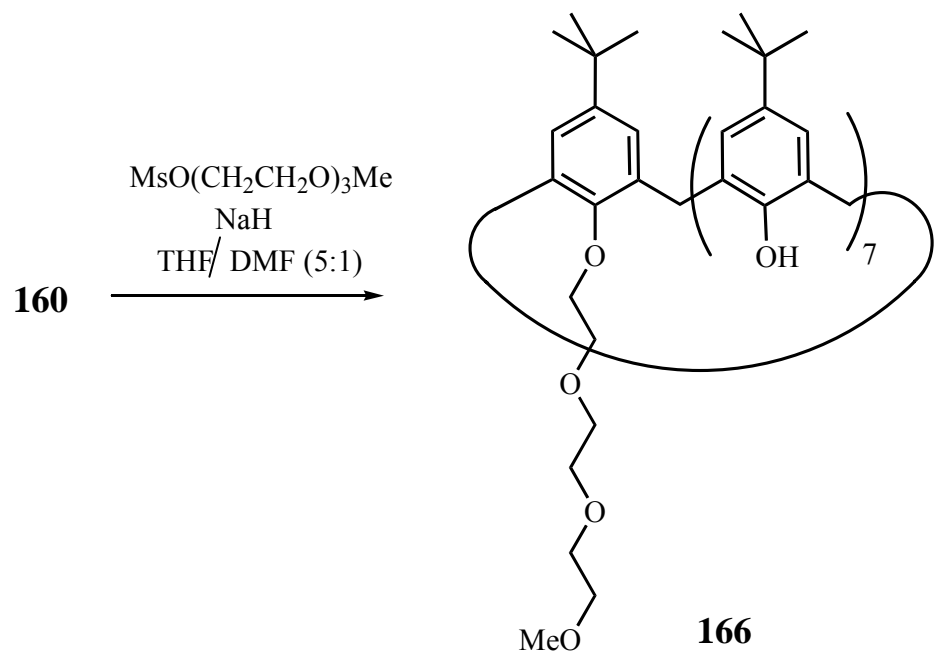

\section{Scheme 46}

Partial alkylation of 160 and 161 with $\mathrm{Br}\left(\mathrm{CH}_{2} \mathrm{CH}_{2} \mathrm{O}\right)_{3} \mathrm{Me}$ gave rise to 167 and 168, while the partial alkylation of 159-161 using $\mathrm{Br}\left(\mathrm{CH}_{2} \mathrm{CH}_{2} \mathrm{O}\right)_{6} \mathrm{THP}$ afforded 169-171, respectively.

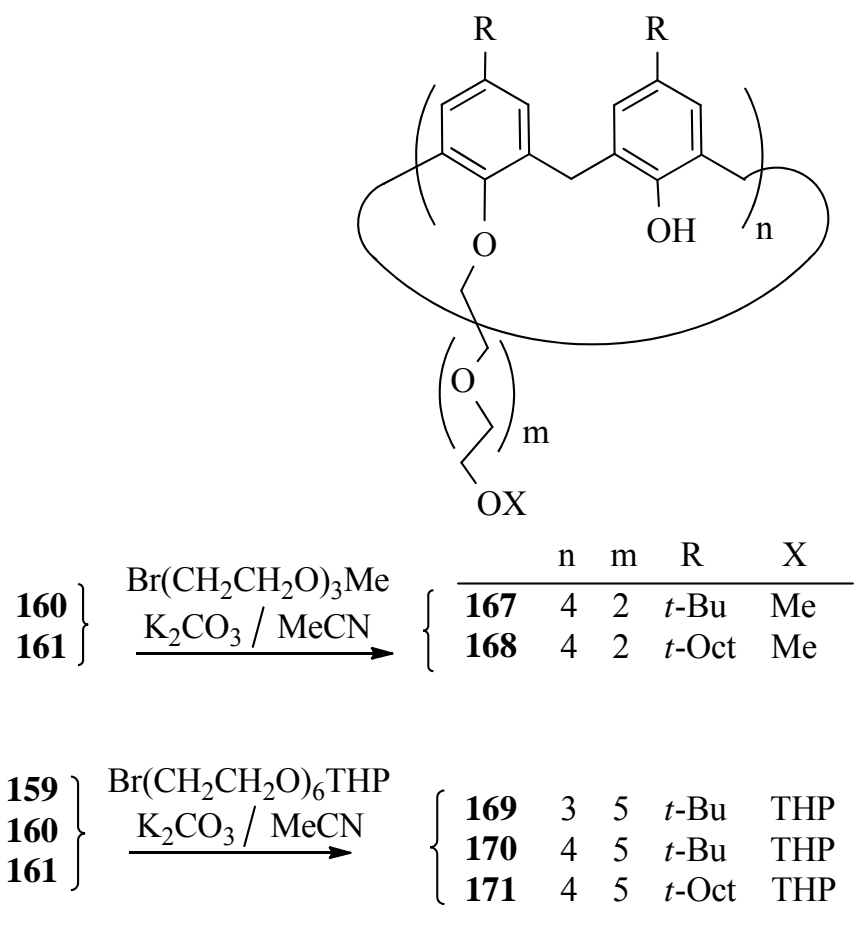

THP $=3$,4-dihydro-2 $H$-pyrane (protecting agent)

\section{Scheme 47}


In order to obtain fully alkylated products, second alkylations of 167 and 168 with $\mathrm{Br}\left(\mathrm{CH}_{2} \mathrm{CH}_{2} \mathrm{O}\right)_{3} \mathrm{Me}$ and of 169-171 with $\mathrm{Br}\left(\mathrm{CH}_{2} \mathrm{CH}_{2} \mathrm{O}\right)_{6} \mathrm{THP}$ afforded 172, 173, and 174-176, respectively.
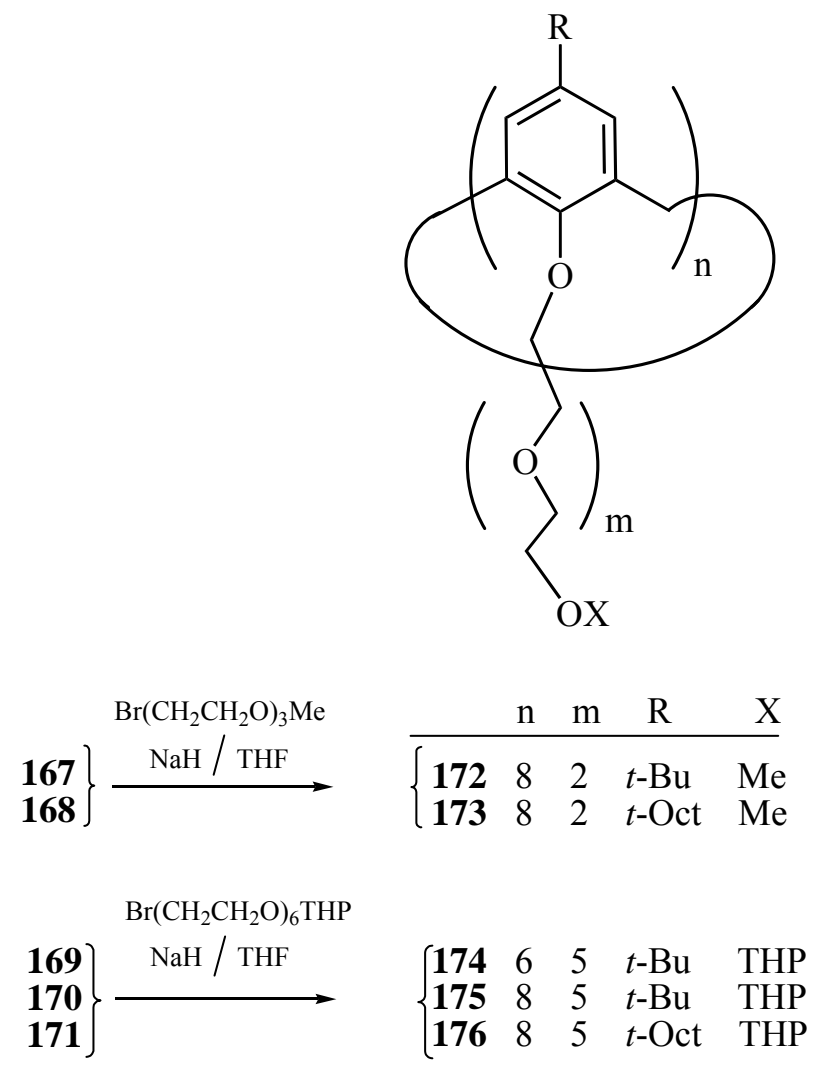

\section{Scheme 48}

The above syntheses of calix[6]arenes and calix[8]arenes functionalized at the narrow rim extend the possibilities of their applications by introduction of various, e.g. solubilizing or fluorescent groups, which could be promising for the design of biological models or molecular sensors. ${ }^{119}$

A large class of calixarenes bridged by crown ethers i.e. calixcrowns, exists, ${ }^{120,121}$ and these are efficient acceptors of metal ions. A related class of compounds are the calixaza-crowns, ${ }^{122-124}$ which also show complexing properties.

The synthesis of an interesting spirobiscalixazacrown $\mathbf{1 7 7}$ has been reported. Its structure consists of two calixazacrown moieties connected by a spiro-carbon atom, for comparison purposes calixazacrown 178, i.e. half-part of 177 was also synthesized. Both 177 and 178 were obtained by the reaction of calixarene $\mathbf{1 7 9}$ with appropriate diamino derivatives 180 and 181, respectively, and were investigated for their complexing properties. ${ }^{125}$ 


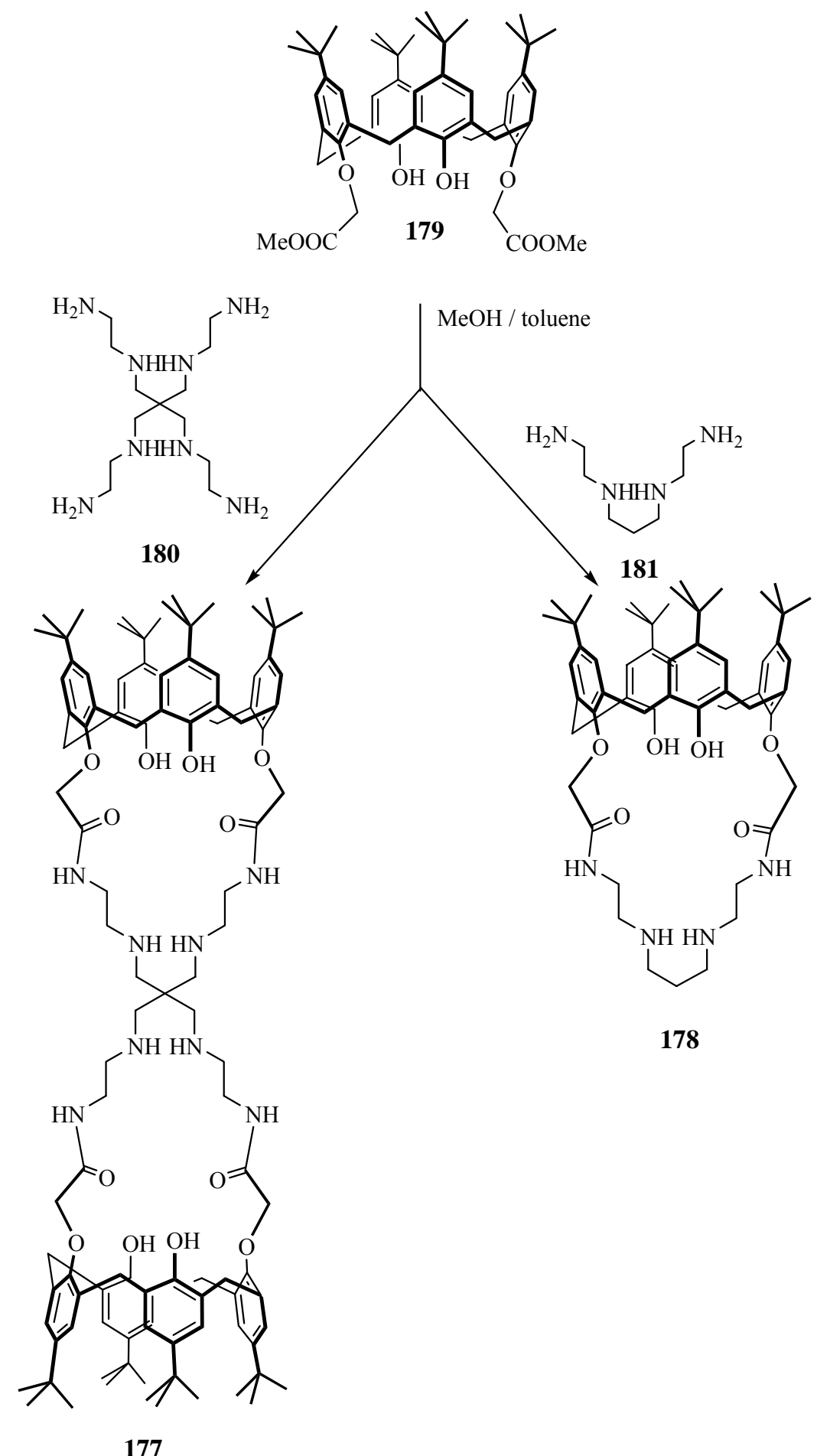

\section{Scheme 49}

It was observed that $\mathbf{1 7 7}$ forms 1:2 complexes, $\mathbf{1 7 7} \cdot \mathbf{M}_{2}$, with $\mathrm{Ag}^{+}, \mathrm{Zn}^{2+}$ and $\mathrm{Fe}^{2+}$ ions, whereas 178 affords 1:1 $\mathbf{1 7 8} \bullet \mathbf{M}$ complexes. In the $\mathbf{1 7 7} \cdot \mathbf{M}_{\mathbf{2}}$ complexes, one metal ion is situated in each cavity. The complexation of $\mathbf{1 7 7}$ with metal ions proceeds slower than complexation of 178 since the next metal ion enters the second cavity of $\mathbf{1 7 7}$ with more difficulty than does the first. 


\section{Functionalization of both rims of calixarenes}

Many functionalization reactions of calixarenes at both rims are known, ${ }^{126-131}$ and some examples are described below. In a study of calixarene chromogenic chemosensors for both cations and anions, ${ }^{132}$ and with the aim to construct molecular logic gates, ${ }^{133,134}$ calixarene 182 recognizing $\mathrm{Ca}^{2+}$ and $\mathrm{I}^{-}$ions has been synthesized. ${ }^{135}$ The process involves the treatment of dipropargylcalixarene 183 with $p$-nitroaniline and $\mathrm{NaNO}_{2}$ affording calixarene 184 containing azo groups which upon click reaction with azide 185 yields calixarene 182.

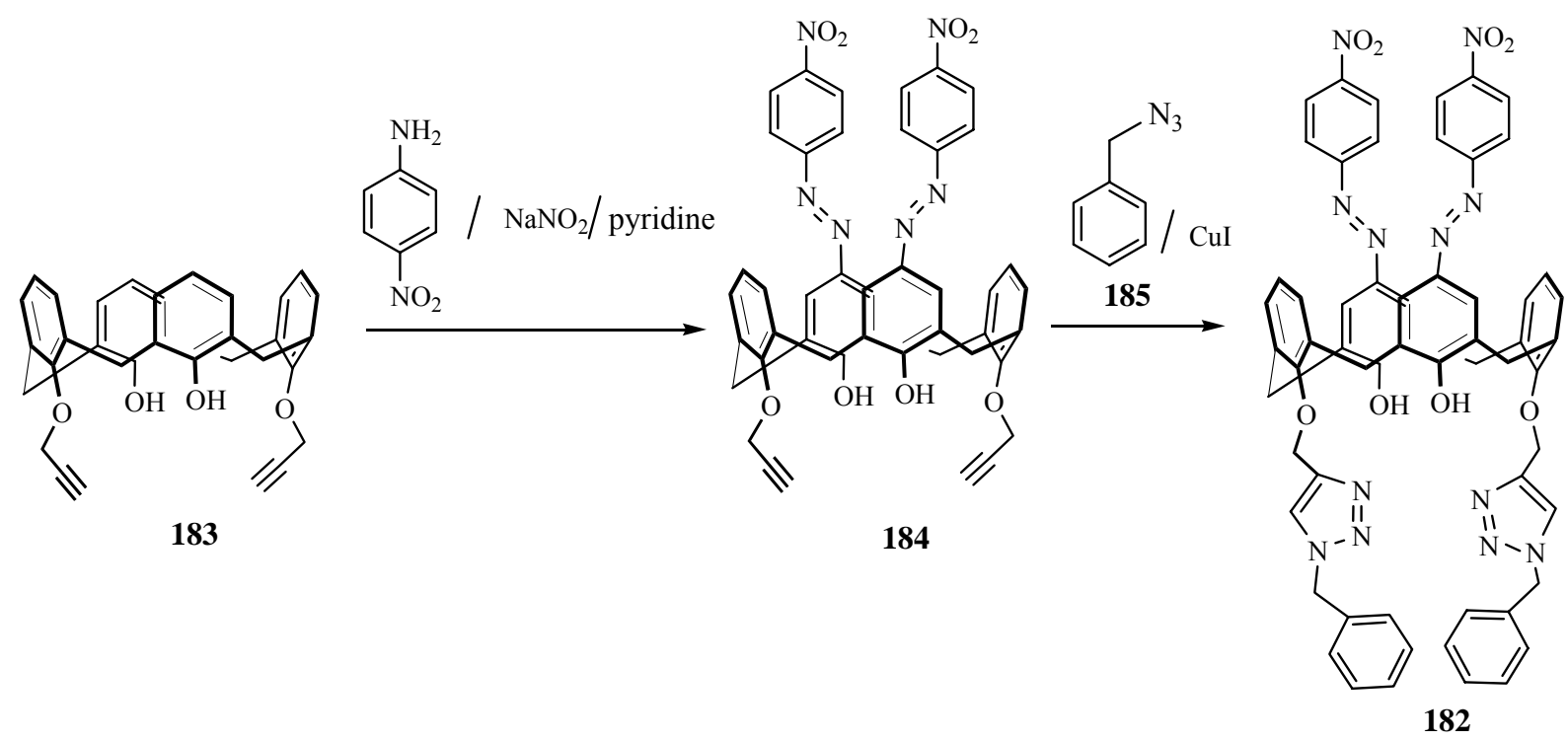

\section{Scheme 50}

Calixarene 182 has triazole units as metal-ligating groups responsible for recognition of $\mathrm{Ca}^{2+}$, $\mathrm{Pb}^{2+}$ and $\mathrm{Ba}^{2+}$ ions, while its phenol hydroxyl groups are responsible for binding of $\mathrm{F}^{-}, \mathrm{AcO}^{-}$and $\mathrm{H}_{2} \mathrm{PO}_{4}{ }^{-}$anions. The color changes resulting from the presence of azo groups are distinct and may be detected by naked eye. The UV/Vis spectral behavior of 182 toward $\mathrm{Ca}^{2+}$ and $\mathrm{F}^{-}$ions enables the construction of a dual output molecular switch, as an INHIBIT logic gate with a YES logic function; the system is operated by inputs of $\mathrm{Ca}^{2+}$ and $\mathrm{F}^{-}$ions. The above experiments are promising for design of miniaturized molecular level devices.

Synthesis of 1,3-alt calixarenes bearing imidazolyl (186-188) and pyrazolyl (189-191) units has been performed for design of the directional $2 \mathrm{D}$ coordination network. ${ }^{136,137}$ In this process the starting calixarene 192 containing mesitylene rings was chloromethylated to give derivative 193 which reacted with sodium imidazolate and pyrazolate affording compounds 186 and 189, respectively. 


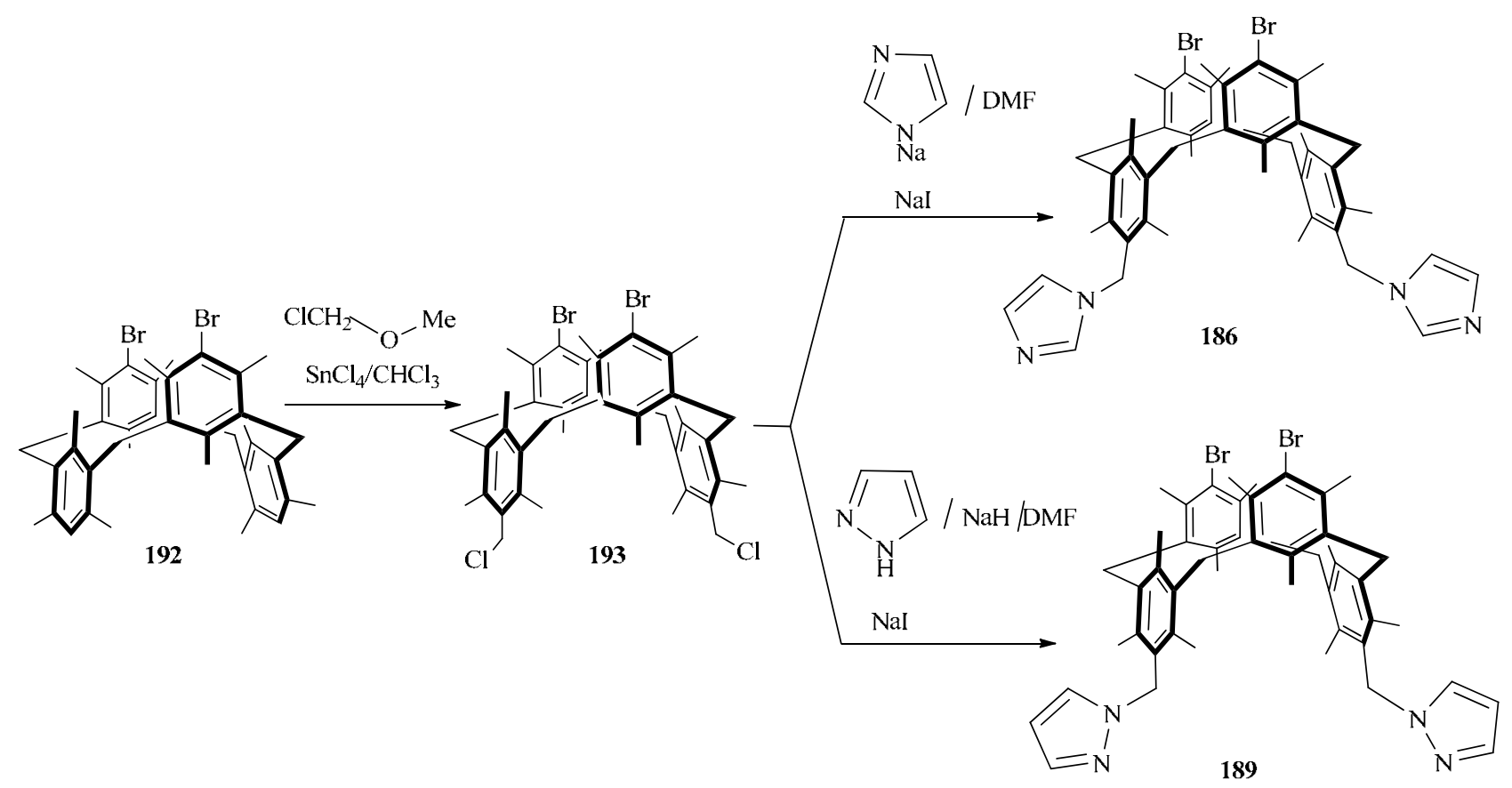

\section{Scheme 51}

Compounds 186 and 189 upon Suzuki coupling with boronic esters 194 and 195 bearing $p$ methylthiophenyl and pyridyl groups, respectively, performed with the use of $\operatorname{Pd}\left(\mathrm{PPh}_{3}\right)_{4}$ as a catalyst, yielded in the case of 186 compounds 187 and 188, and in the case of 189 compounds 190 and 191.

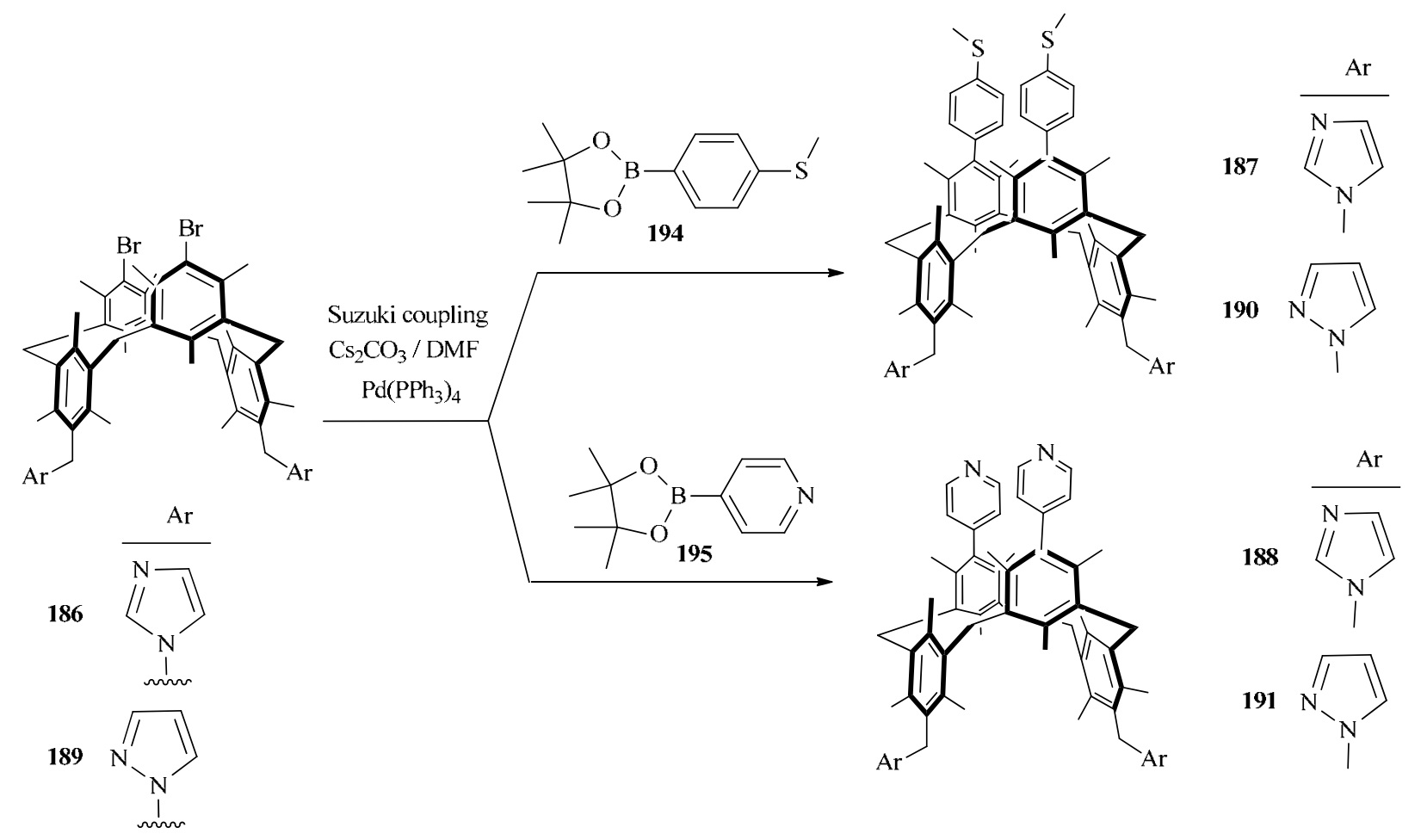




\section{Scheme 52}

The structural investigation has shown that $\mathbf{1 8 6}$ affords crystalline discrete metallamacrobicycles in the presence of metal halides $\mathrm{MX}_{2}(\mathrm{M}=\mathrm{Co}, \mathrm{Zn}, \mathrm{Cu}, \mathrm{Hg} ; \mathrm{X}=\mathrm{Cl}$ or $\mathrm{Br})$, whereas 189 forms infinite $1 \mathrm{D}$ coordination networks with $\mathrm{CoX}_{2}(\mathrm{X}=\mathrm{Cl}$ or $\mathrm{Br})$ and with $\mathrm{ZnCl}_{2}$. It was found however that the acentric 191 bearing two pyrazolyl and two pyridyl groups forms the desired directional 2D coordination network with $\mathrm{ZnCl}_{2}$.

The water soluble calixarenes 196a,b having deep cavities were synthesized with the aim to investigate their inclusion complexation with pyridines and with aromatic cations. ${ }^{138}$ The synthesis begins with the reduction of calixarenes $197 \mathbf{a}, \mathbf{b}$ with $\mathrm{BH}_{3} \cdot$ THF complex affording 198a,b which upon treatment with ethyl bromoacetate yield esters 199a,b. The subsequent hydrolysis of 199a,b leads to 196a,b as potassium salts, bearing eight and twelve potassium carboxylate units, respectively.

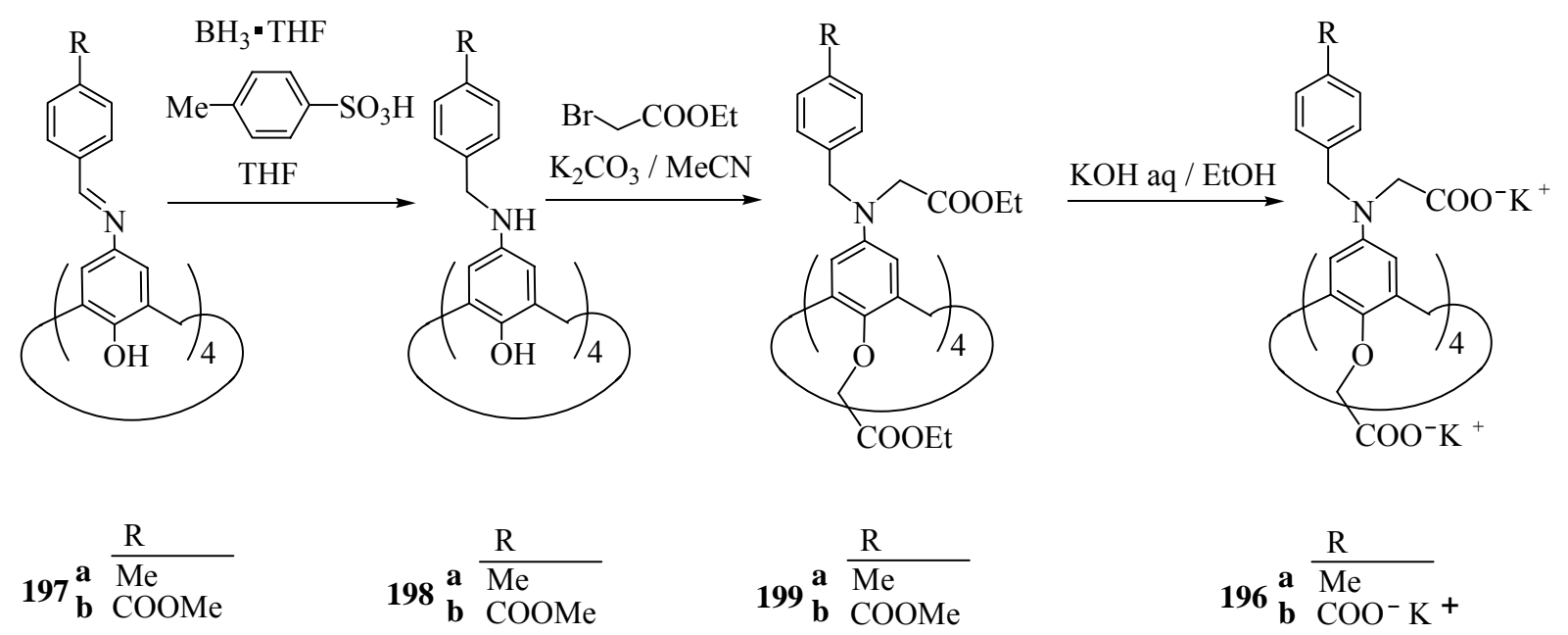

\section{Scheme 53}

It is noteworthy that $\mathbf{1 9 6 a}$ and $\mathbf{1 9 6 b}$ are both water soluble and highly stable, calixarene 196a has a hydrophobic, and $\mathbf{1 9 6 b}$ a hydrophilic cavity. It was found that 196a,b form 1:1 inclusion complexes with pyridines 200, 201 and aromatic cations 202-206. The 196b•203 complex showed the highest binding constant.

Comparing complexing properties of 196a and 196b, it was found that 196a binds 200 and 201 more strongly than 196b does, whereas 196b binds 202-206 more strongly than 196a does. Comparing properties of guests it was observed that 196a binds more strongly with 200 and 201 than with 202-206. The affinity of 202 and 203 as guests of 196a and of 196b is higher for 203 than for 202, this fact showing that the presence of the methyl group in the ring of 203 enhances its binding strength. All of the above experiments were performed in aqueous medium and therefore they are of interest for investigation of biological processes. 
<smiles>CCc1ccncc1</smiles><smiles>Cc1ccc(CC[NH3+])cc1</smiles>

Pyridines and aromatic cations used as guest molecules of 196a,b

\section{Scheme 54}

It is known that chiral, especially inherently chiral calixarenes are able to include enantiomers of chiral guest molecules, this property being of a great value, e.g. in the design of chiral advanced materials, in the preparation of enantioselective sensors and in asymmetric synthesis. In this aspect both enantiomers of inherently chiral calixarenecarboxylic acids 207a and 207b with ABCD substitution patterns have been prepared. ${ }^{139}$

Calixarene 208 was reacted with $(R+)-N-(\alpha$-phenylethyl)bromoacetamide affording calixarene 209 and benzoylation of one its hydroxyl groups leads to the mixture of paco diastereomers 210a and 210b. Diastereotopicity of 210a and 210b results both from the presence of the chiral carbon atom of phenylethylamide group and of the ABCD asymmetrical substitution of the calixarene macrocycle. Diastereomers 210a and 210b were separated by column chromatography and regioselectively brominated with NBS to give monobromocalixarenes 211a and 211b. The phenylethylamide and benzoyl groups of 211a and 211b were removed by treatment with $\mathrm{KOH}$ in ethanol/water medium affording chiral cone carboxylic acids 207a and 207b which are promising for the chiral recognition of organic compounds.

In the study of calixarene self-organized solids, the calixarenequinhydrone charge-transfer complex 212 has been synthesized. ${ }^{140}$ For this purpose, dimethoxycalixarene 213 was oxidized with thallium (III) trifluoroacetate to give calixarenediquinone $\mathbf{2 1 4}$ which, upon reduction with sodium borohydride, yielded calixarenedihydroquinone 215. 

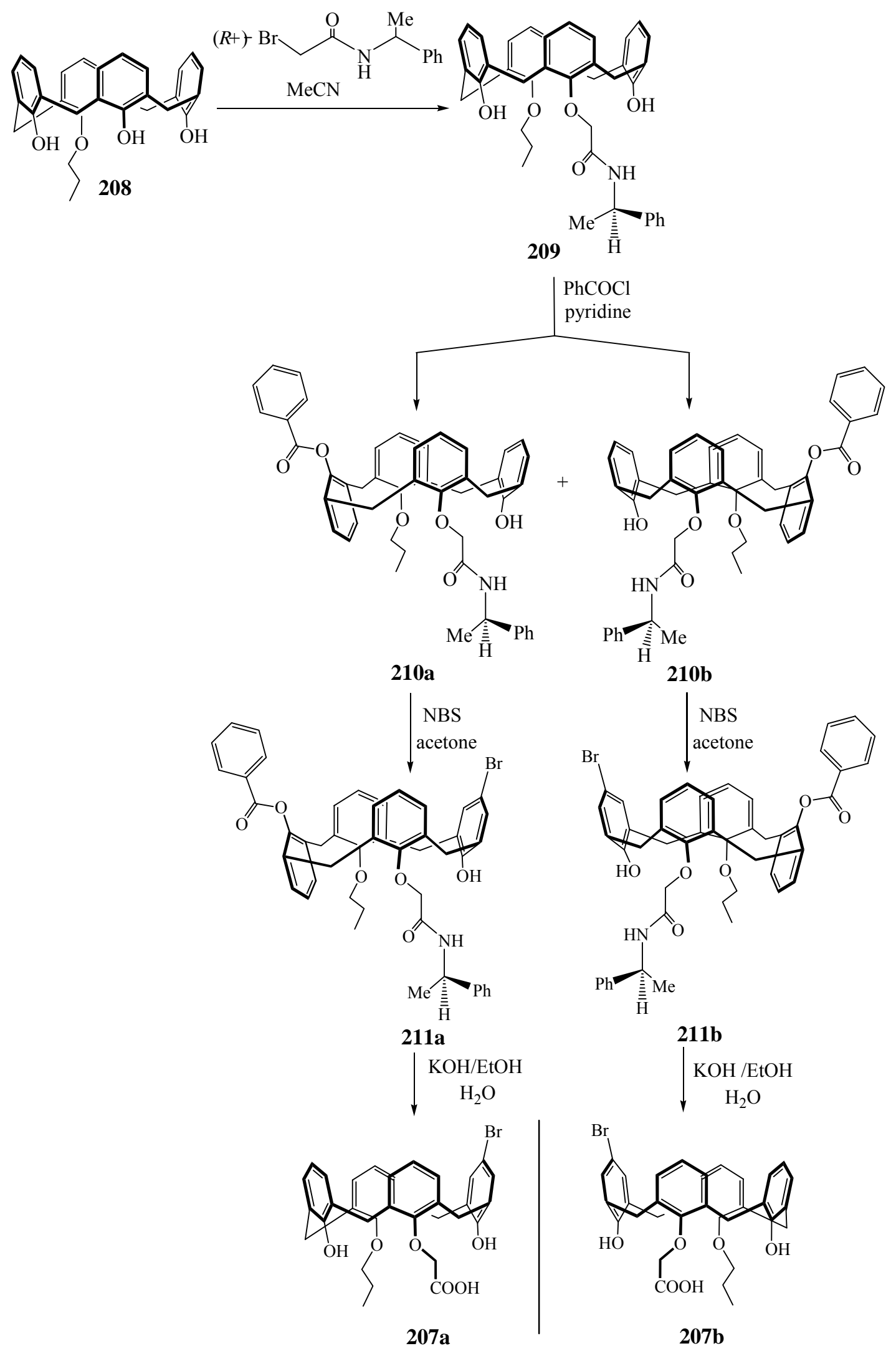

\section{Scheme 55}




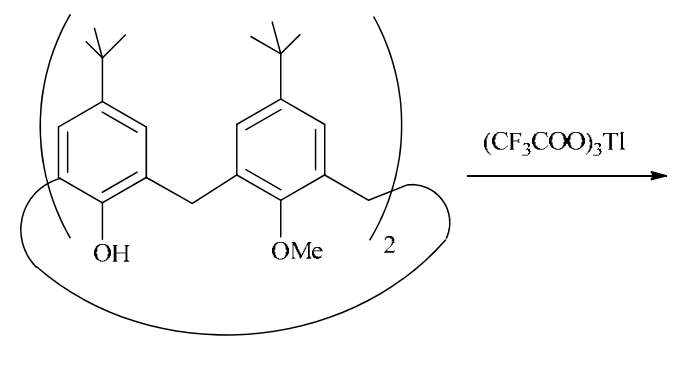

213

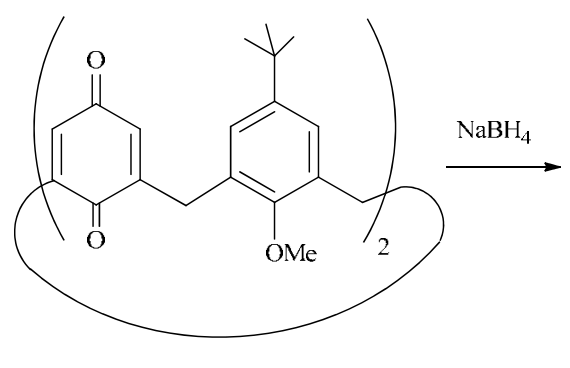

214

calixarenediquinone

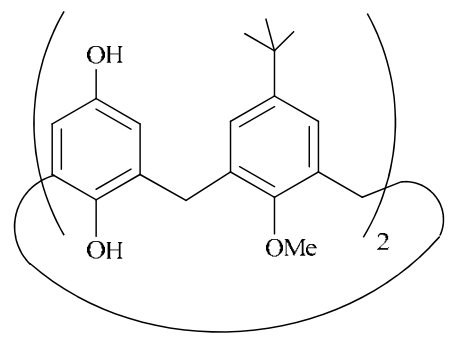

215

calixarenedihydroquinone

\section{Scheme 56}

The direct synthesis of $\mathbf{2 1 2}$ by mixing calixarenediquinone 214 and calixarenedihydroquinone 215 was impossible due to the lack of solubility of 215 . Therefore, 212 was prepared by partial reduction of $\mathbf{2 1 4}$ with $\mathrm{NaH}$, leading to formation of the sodium salt of 212. It was observed that $\mathbf{2 1 2}$ shows solvatochromism in the visible region and this result is promising for use of quinhydrone type calixarenes in the design of sensors.

The electrophilic ipso-nitration reactions of calix[6]arene 216 bearing three methylimidazolyl groups in alternate ring positions have been performed. It was observed that the reaction of $\mathbf{2 1 6}$ with fuming nitric acid and glacial acetic acid at room temperature in $\mathrm{CH}_{2} \mathrm{Cl}_{2}$ leads to partial ipsonitration, affording tris-nitrated product. However, the reaction of $\mathbf{2 1 6}$ with concentrated sulfuric acid at $60{ }^{\circ} \mathrm{C}$ leads to ipso-sulfonation of all benzene rings, affording hexa-sulfonated compound 218. ${ }^{141}$
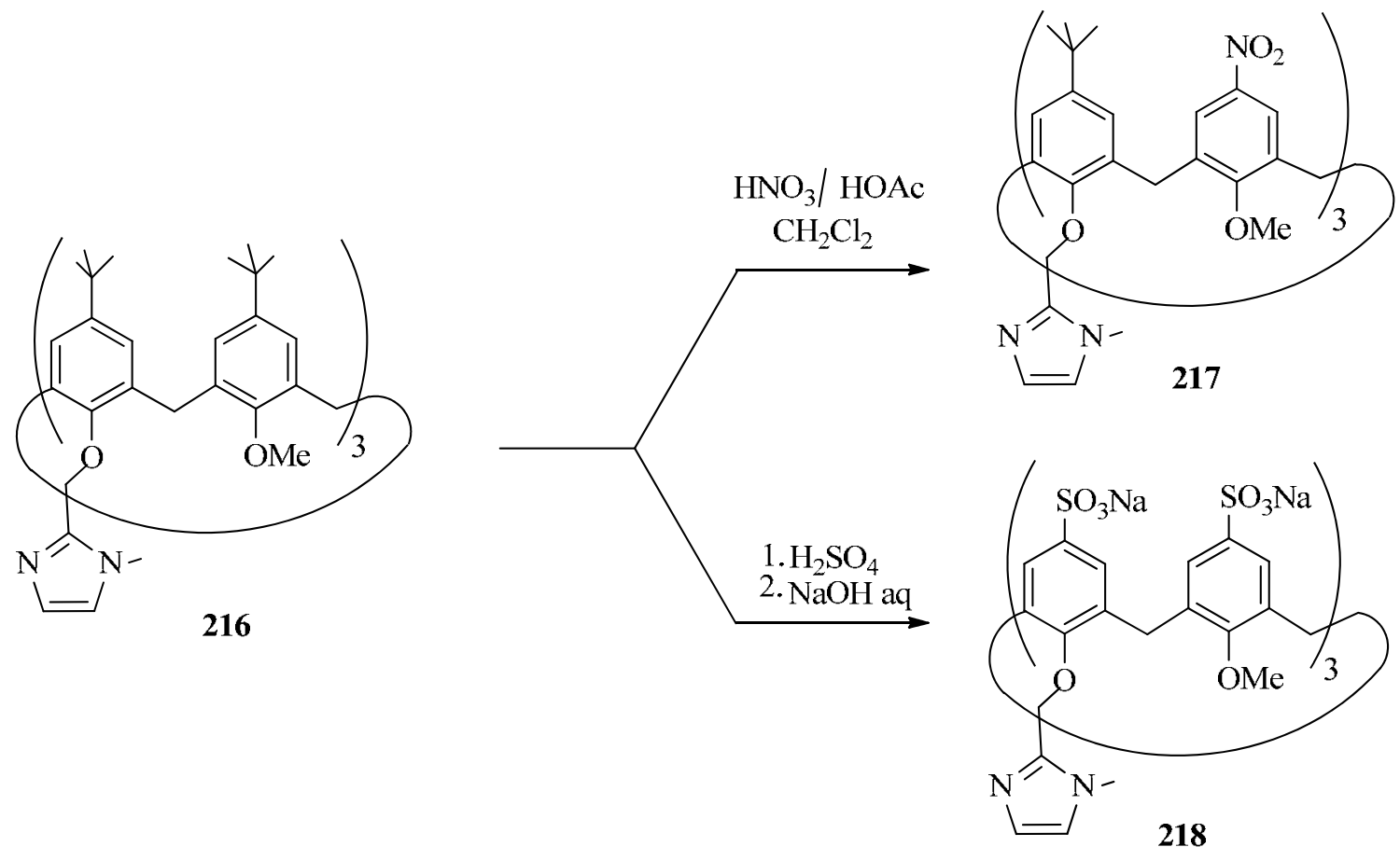


\section{Scheme 57}

In order to understand why the nitration proceeds only on the anisole rings in preference to imidazolyl-substituted rings, the nitration was performed on calix[6]arenes bearing other than methylimidazolyl groups, for this purpose, calixarenes 219a-c containing amino groups and 220 containing $i$-butyl groups have been used. Calixarenes 219a,b were obtained by known procedures, ${ }^{142}$ calixarenes 219c and 220 were synthesized from 219d by treatment with 3-(N,Ndimethylamino)propylchloride and $i$-butyl iodide, respectively.
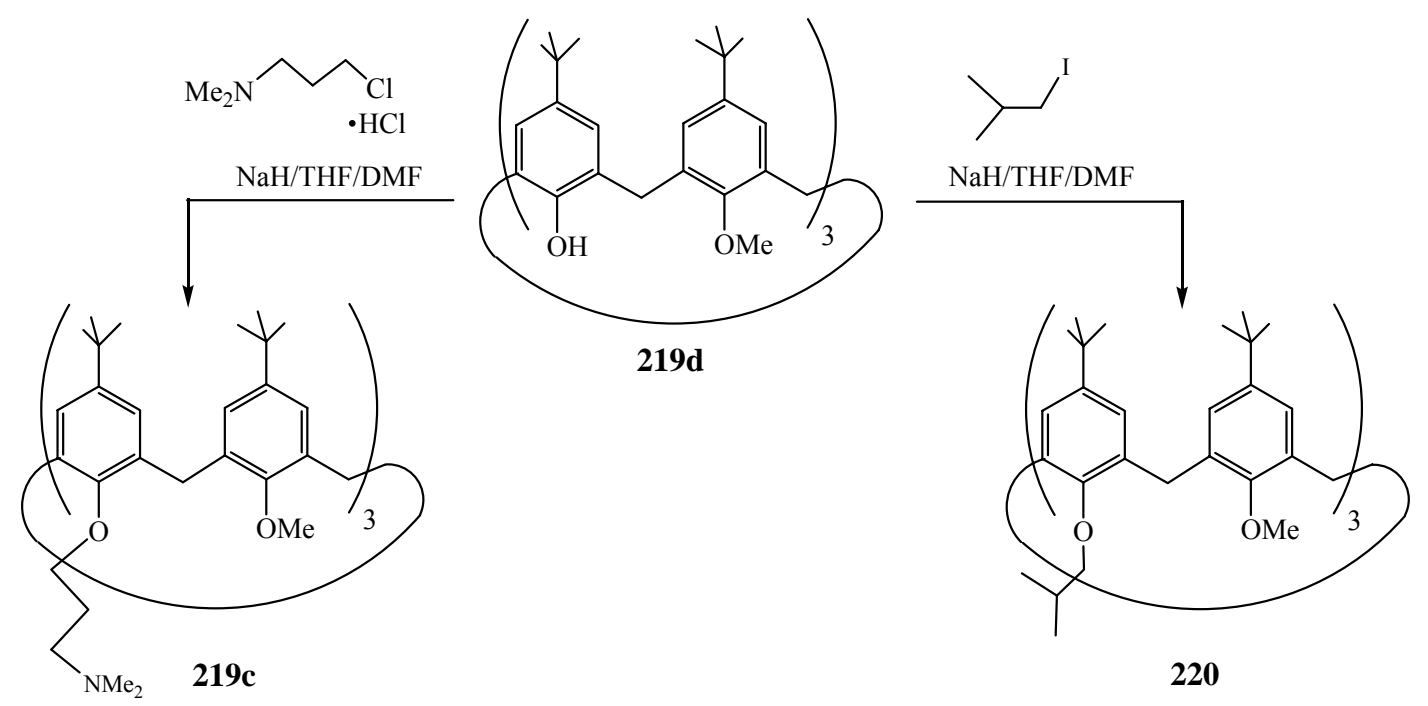

\section{Scheme 58}

Calixarenes 219a-c and 220 were nitrated as in the case of 216, it was observed that 219a-c afforded the tris-nitrated products 221a-c, whereas from 220 the hexa-nitrated product 222 has been obtained.
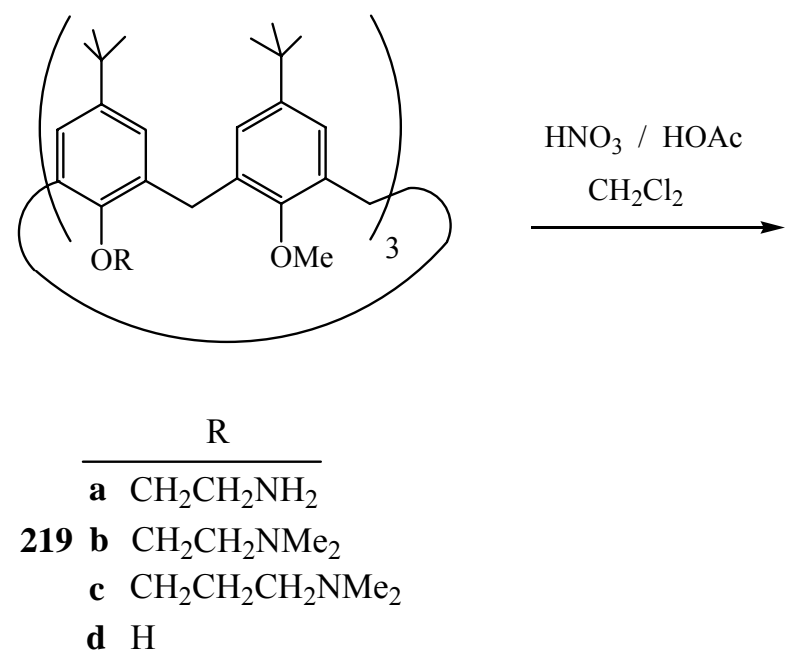

$$
\begin{aligned}
\frac{\mathrm{C}}{\mathbf{a}} & \mathrm{CH}_{2} \mathrm{CH}_{2} \mathrm{NH}_{2} \\
\mathbf{2 2 1} \mathbf{b} & \mathrm{CH}_{2} \mathrm{CH}_{2} \mathrm{NMe}_{2} \\
\text { c } & \mathrm{CH}_{2} \mathrm{CH}_{2} \mathrm{CH}_{2} \mathrm{NMe}_{2}
\end{aligned}
$$

\section{Scheme 59}


The crucial role of the substituent $\mathbf{R}$ may be explained by the presence of a protonable site in this group. Calixarene 216 containing methylimidazolyl groups as well as calixarenes 219a-c containing arms with primary and tertiary amino groups, are protonated under the strongly acid nitration conditions. These protonated amino groups form hydrogen bonds with the phenolic oxygen atoms of calixarene, therefore the whole aromatic ring has lower electron density, i.e. is deactivated toward electrophilic attack of nitronium ion $\mathrm{NO}_{2}{ }^{+}$. As a result, in 219a-c, the nitration proceeds only on the anisole rings and not on the rings containing amino groups. However, in 220, where the amino groups are absent, such deactivation does not exist and therefore the nitration affords hexanitrated product 222.
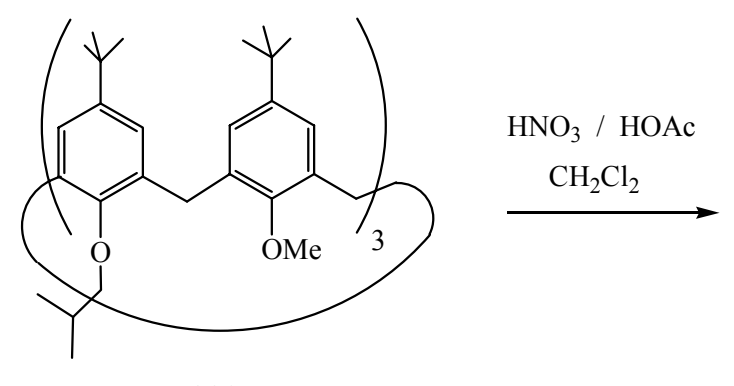

220

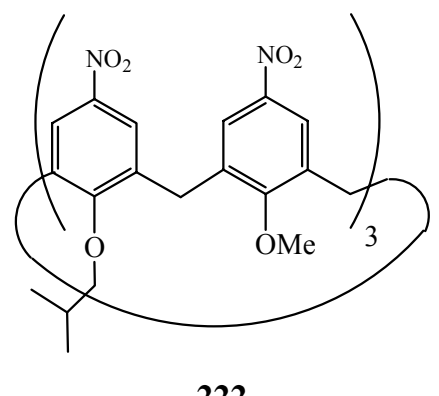

\section{Scheme 60}

It should be pointed out that the studied selective ipso-nitration of calix[6]arenes allows the direct introduction of three nitro groups in alternate rings, therefore the disymmetrization of the wide rim is possible. This selectivity depends on the nature of the substituents on the phenolic rings of the calixarenes. Facile reduction of the nitro groups leading to amino groups opens further synthetic perspectives for selectively functionalized calix[6]arenes. ${ }^{141}$

With the consideration of usefulness of amino groups, 1,3-alt calix[4]arenes bearing four or eight amino groups have been synthesized. ${ }^{143}$

In order to obtain tetraaminocalixarenes the following reactions were performed. The reaction of calixarene 92 with $N$-bromopropylphthalimide affords 223 which with bromopropylnitrile gives 224, this compound can be also obtained from 92 by treatment with bromopropylnitrile yielding 925, subsequently reacted with $N$-bromopropylphthalimide. Cleavage of 224 with hydrazine in ethanol proceeds without reduction of the nitrile groups to give 226, this compound was acetylated affording 227 which upon reduction yielded 228. 


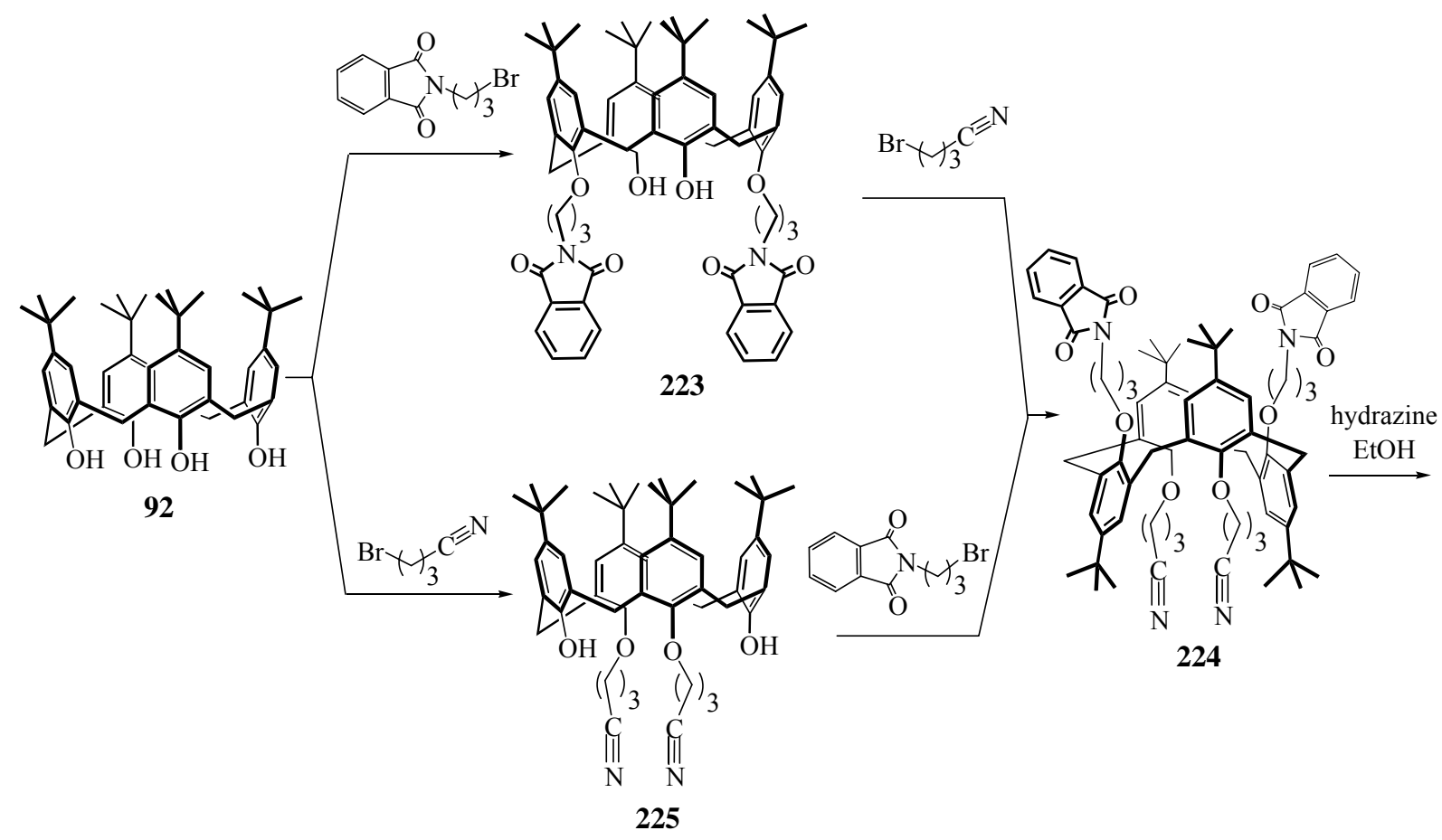

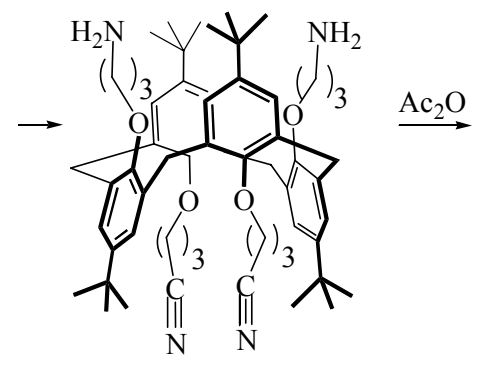

226

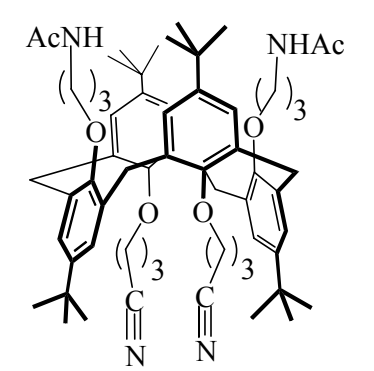

227

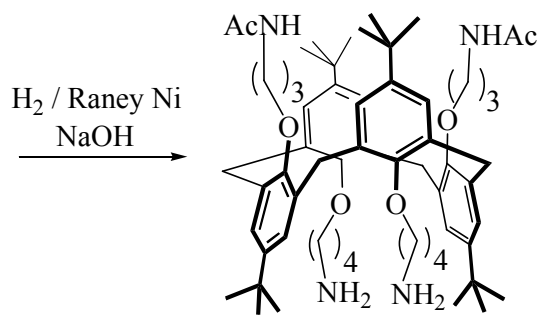

228

\section{Scheme 61}

The $\mathrm{O}$-allylation of $\mathbf{2 2 9}$ with allylbromide gives rise to $\mathbf{2 3 0}$ which by simultaneous reduction of nitro groups and hydrogenation of $\mathrm{C}=\mathrm{C}$ double bonds affords diaminocalixarene 231. The protection of amino groups of $\mathbf{2 3 1}$ by phthalimide units leads to 232, which was submitted to ipsonitration yielding dinitrocalixarene 233. The treatment of compound 233 with hydrazine in ethanol by cleavage of the phthalimide groups gives 234 , and catalytic hydrogenation of the nitro groups affords 235. 


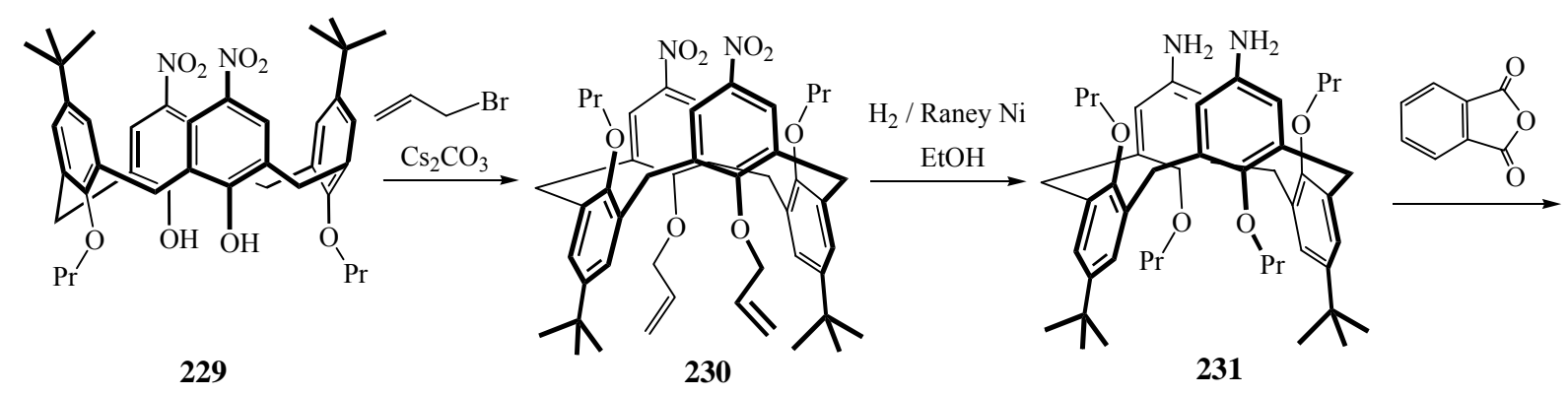

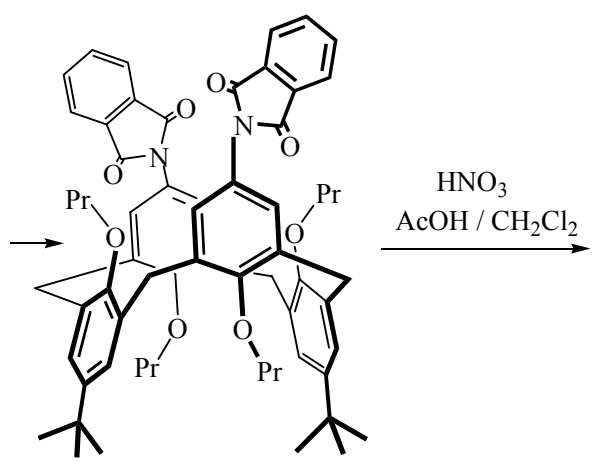

232

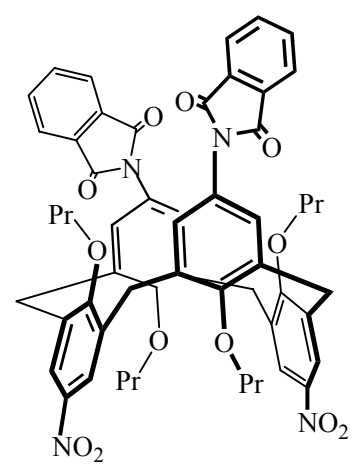

233

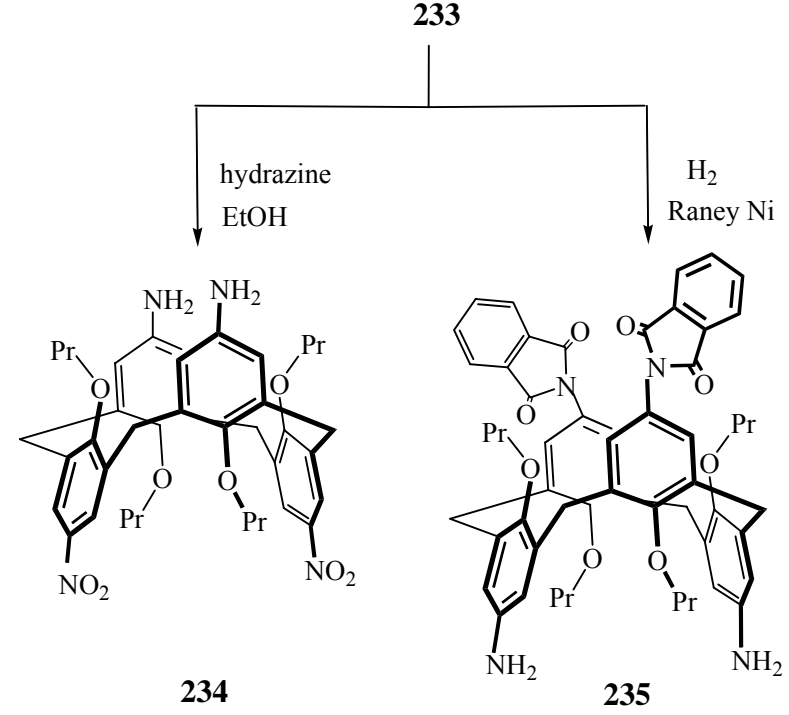

\section{Scheme 62}

Investigation of the partial protection of $\mathbf{2 3 6}$ by Boc has shown that the reaction with two Boc anhydride equivalents leads to mono-and diprotected calixarenes 237 and 238, while the use of three Boc anhydride equivalents affords tri-and tetraprotected 239 and 240, respectively. 


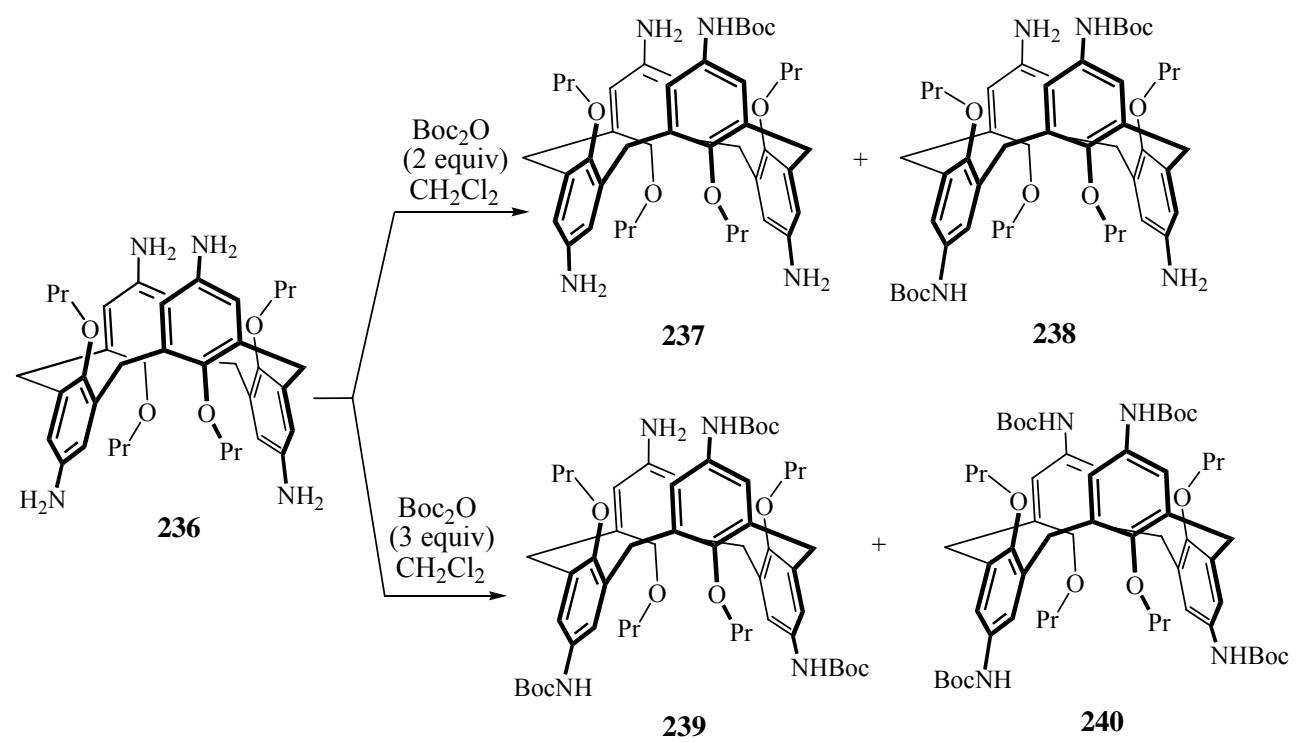

\section{Scheme 63}

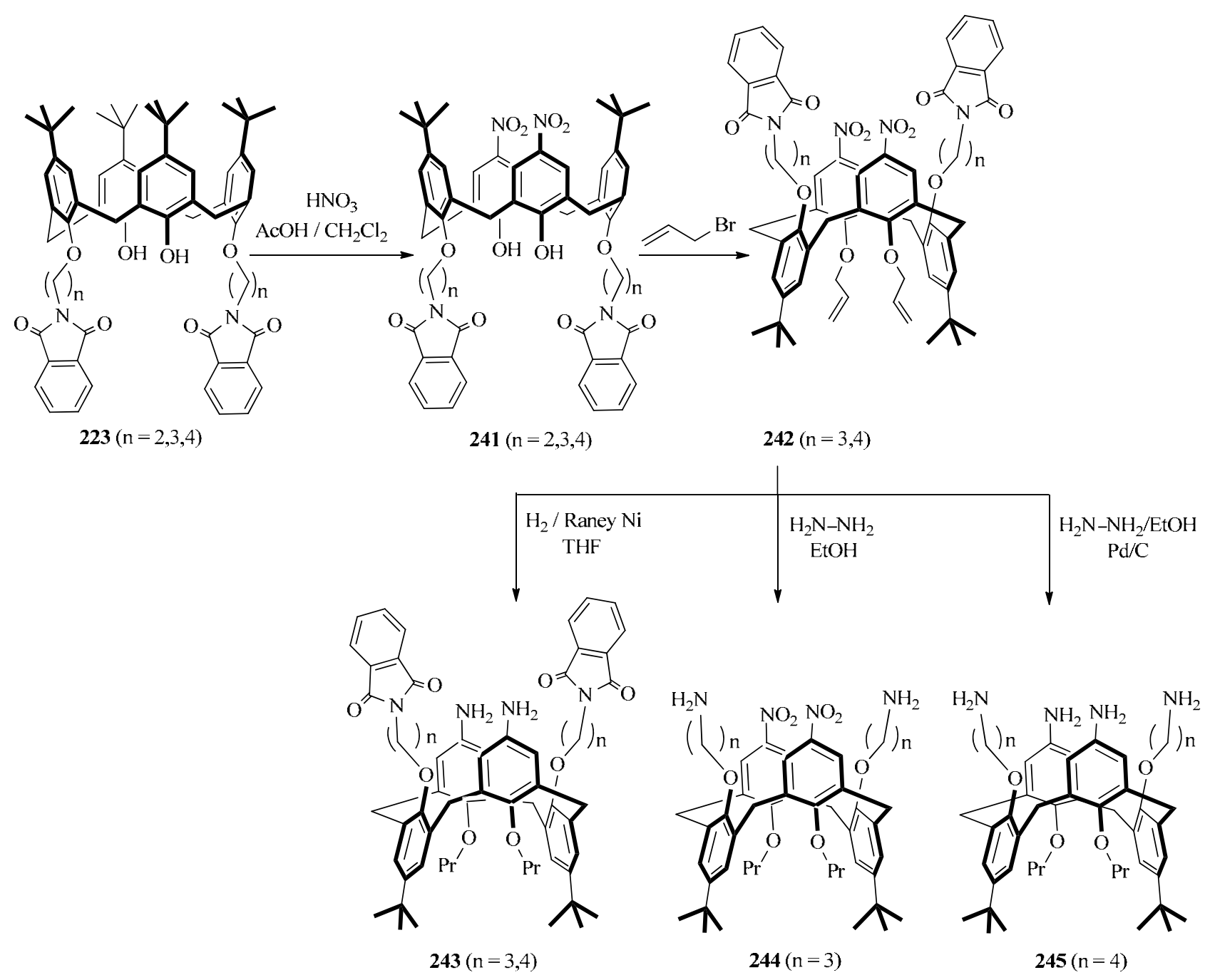

\section{Scheme 64}


Calixarene 223 was ipso-nitrated to give 241 which, with allyl bromide yields 242, which in turn, is catalytically reduced to 243. Compound 242 treated with hydrazine in EtOH affords 244 in which the nitro groups are retained, however when this reaction proceeds in the presence of $\mathrm{Pd} / \mathrm{C}$ catalyst it leads to tetraaminocalixarene 245.

In order to obtain octaaminocalixarenes, the following reactions were performed. Calixarene 92 was treated with $\mathrm{N}$-bromopropylphthalimide to give $\mathbf{2 4 6}$ which upon ipso-nitration yields 247 . The catalytic reduction of the nitro groups of 247 affords 248, while reaction of 247 with hydrazine in EtOH results in the cleavage of the phthalimido groups affording 249 . Reaction of 247 with hydrazine in $\mathrm{EtOH}$ in the presence of $\mathrm{Pd} / \mathrm{C}$ causes simultaneous cleavage of the phthalimido groups and reduction of the nitro groups leading to the octaaminocalixarene 250. The presence of amino groups in calixarenes is of a great importance for their further reactions. ${ }^{143}$

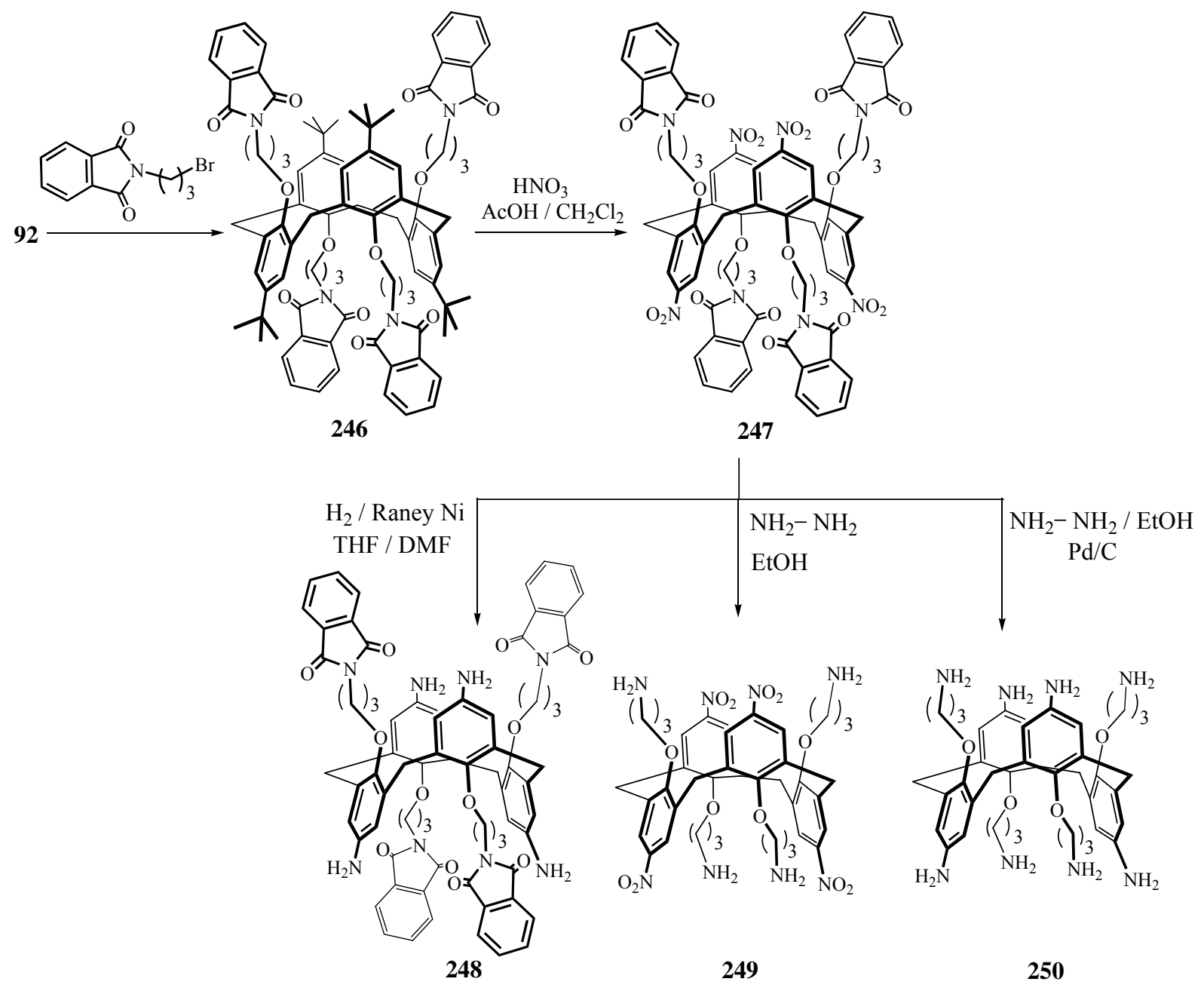

\section{Scheme 65}

Due to their redox properties, porphyrins are important components in crucial biological electron-transport systems such as respiration and photosynthesis. Porphyrins have high electronic excitation energy, allowing light/electricity conversion and are thus promising for their use in solar 
cells. ${ }^{144-147}$ It has been reported that anionic calixarene 251 may form noncovalent assemblies with free base or metallated $\left(\mathrm{M}=\mathrm{Cu}^{2+}, \mathrm{Zn}^{2+}, \mathrm{Au}^{3+}\right)$ cationic porphyrins $\mathbf{A}^{148}$

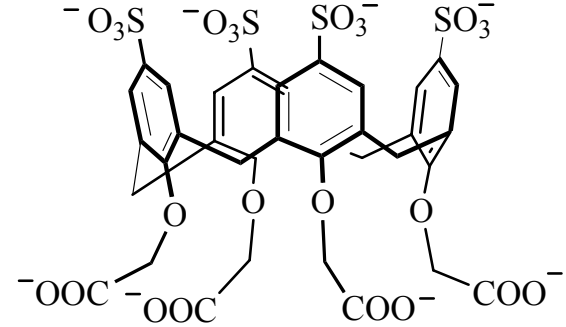

251

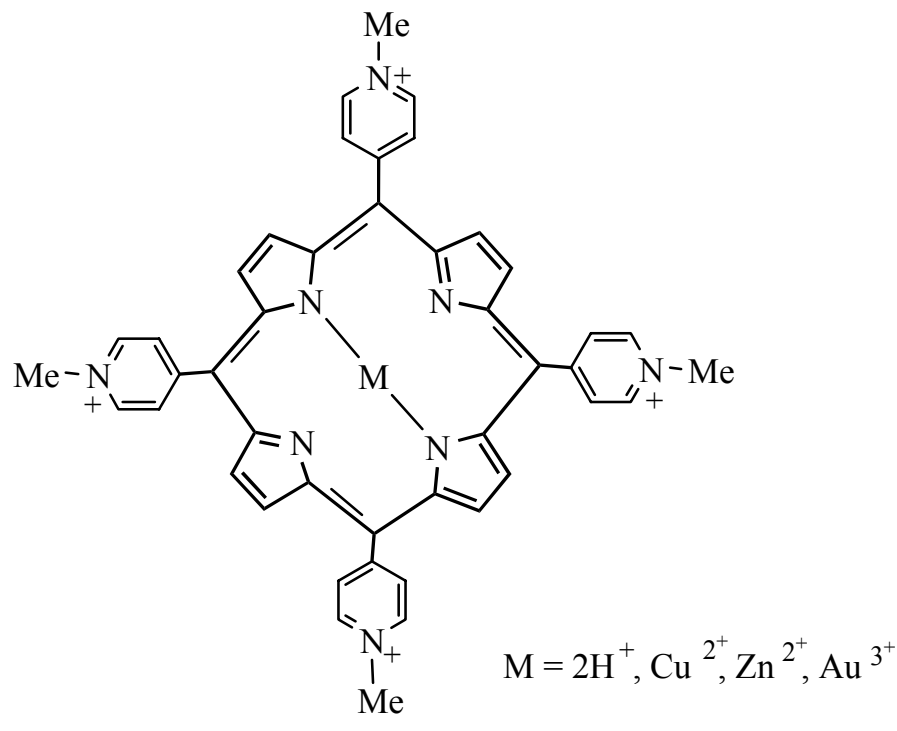

A

\section{Scheme 66}

The titration of $\mathbf{2 5 1}$ with aliquots of porphyrins $\mathbf{A}$ initially forms the central core, i.e. $\mathbf{2 5 1}_{4} \bullet \mathbf{A}$ serving as a template for complexing further porphyrin units. The subsequent addition of two equivalents of porphyrin A leads to formation of the assembly $\mathbf{2 5 1}_{4} \cdot \mathbf{A}_{3}$ in which the added $\mathbf{A}$ molecules are situated above and below the central core plane (i.e. before and behind the top view plane), the next two A molecules afford $\mathbf{2 5 1}_{4} \bullet \mathbf{A}_{5}$ assembly, and addition of further two A molecules leads to $\mathbf{2 5 1}_{4} \cdot \mathbf{A}_{7}$ assembly.

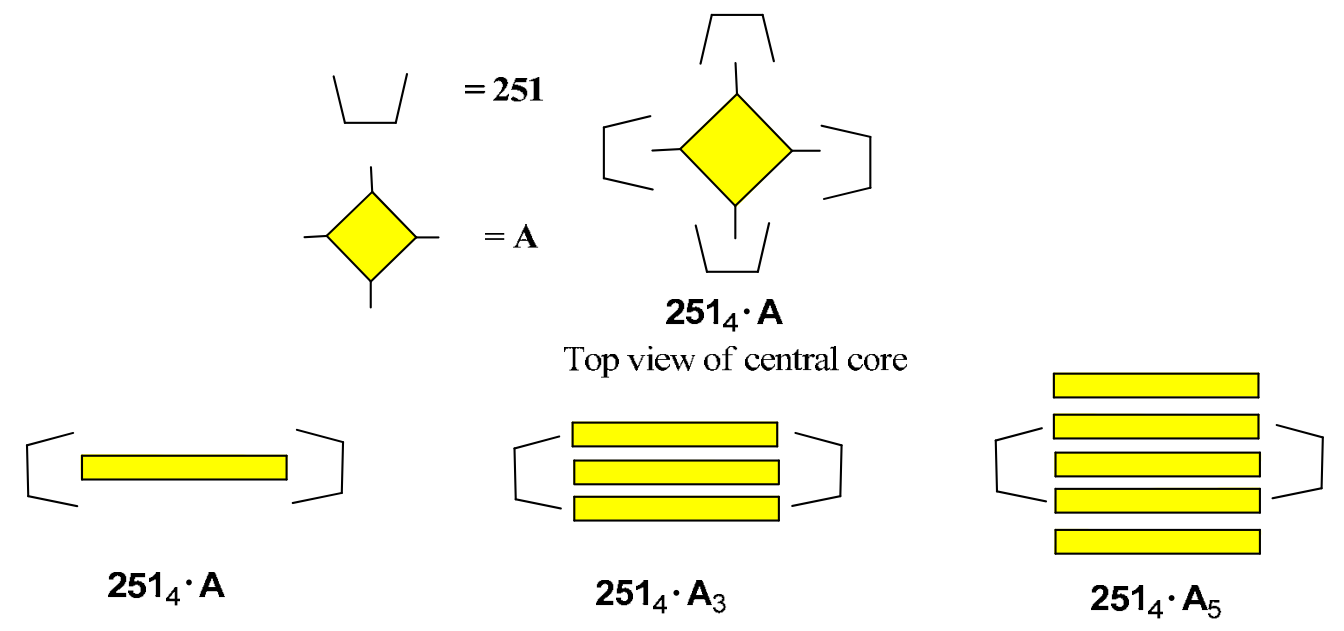

Side view of central core $251_{4} \cdot A$ along with $\mathbf{2 5 1}_{4} \cdot \mathbf{A}_{3}$ and $251_{4} \cdot \mathbf{A}_{5}$ assemblies (two calixarene molecules of the central core, which are situated before and behind the figure plane are omitted for clarity)

\section{Scheme 67}


Porphyrins used may be different and the core porphyrin may be metallated or not; the sequence and stoichiometry of formed assemblies depend on the order of addition and number of used porphyrin equivalents. The above assemblies with desired porphyrin sequences are promising for construction of molecular devices.

As a continuation of the above investigations, ${ }^{148}$ the noncovalent assemblies of octacationic biscalixarene 252 with tetraanionic copper porphyrin $\mathbf{B}$ have been synthesized, ${ }^{149}$ the templating agent 252 is water soluble and has cavities oriented in a divergent fashion.

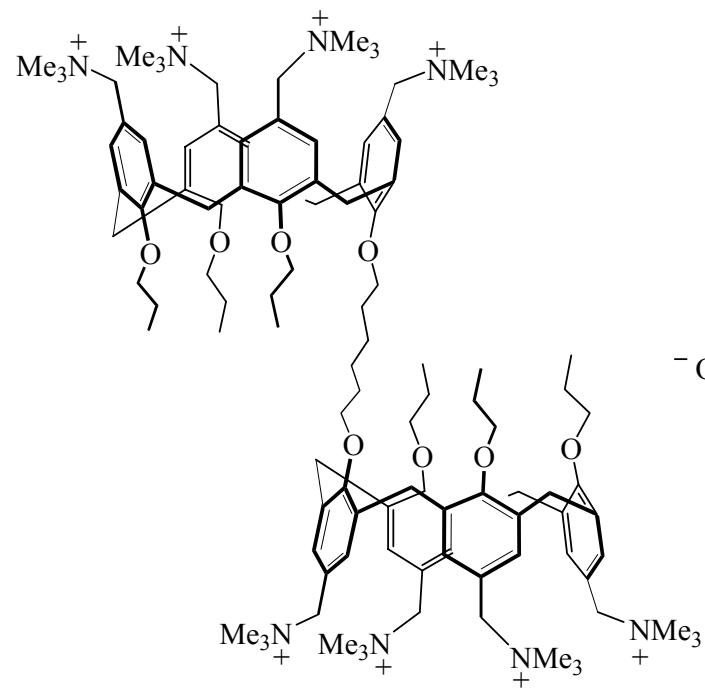

252

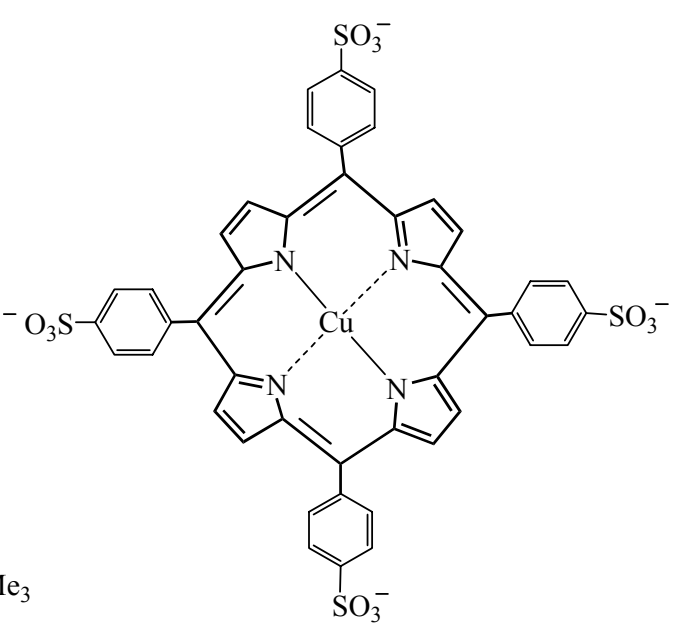

B

\section{Scheme 68}

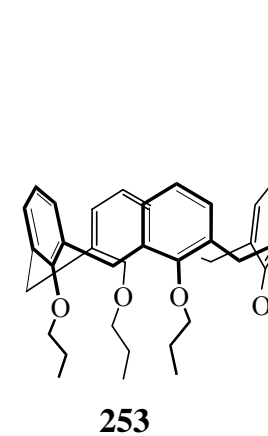

253

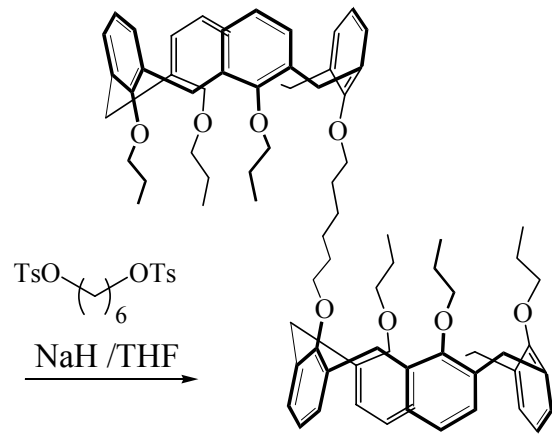

254

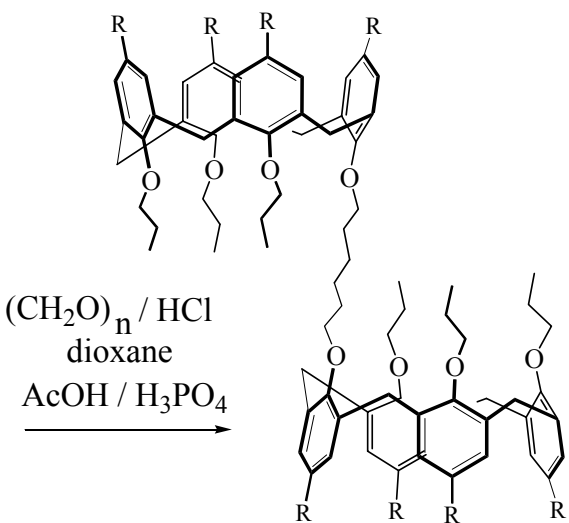

$\left.\begin{array}{ll}255 & \frac{\mathrm{R}}{\mathrm{CH}_{2} \mathrm{Cl}} \\ 252 & \mathrm{CH}_{2}^{-} \mathrm{NMe}_{3} \mathrm{Cl}^{-}\end{array}\right] \begin{aligned} & \mathrm{Me}_{3} \mathrm{~N} \\ & \text { dioxane }\end{aligned}$

\section{Scheme 69}


The synthesis of 252 begins by the treatment of calixarene 253 with 1,6-hexanediyl ditosylate affording 254 which reacts with paraformaldehyde and $\mathrm{HCl}$ in dioxane to give 255. The amination of 255 with $\mathrm{Me}_{3} \mathrm{~N}$ yields bis-calixarene 252 .

During the UV/Vis titration, the aqueous solution of 252 was treated stepwise with $\mathbf{B}$ aliquots. Initially the central core $\mathbf{2 5 2} \mathbf{2}_{4} \mathbf{B}$ is formed, which upon addition of four $\mathbf{B}$ equivalents affords the $\mathbf{2 5 2}_{4} \cdot \mathbf{B}_{5}$ assembly. The subsequent treatment of $\mathbf{2 5 2}_{4} \cdot \mathbf{B}_{5}$ with two $\mathbf{B}$ equivalents yields the $3 \mathrm{D}$ $\mathbf{2 5 2}_{4} \cdot \mathbf{B}_{7}$ assembly, (i.e. $\mathbf{2 5 2}_{4} \cdot \mathbf{B}_{5}$ in which two added $\mathbf{B}$ equivalents are situated below and above the central core), whereas the treatment of $\mathbf{2 5 2}_{4} \cdot \mathbf{B}_{5}$ with twelve 252 equivalents leads to the $2 \mathrm{D}$ assembly $252_{16} \cdot \mathbf{B}_{5}$. It is noteworthy that in experiments the different porphyrins may be used.

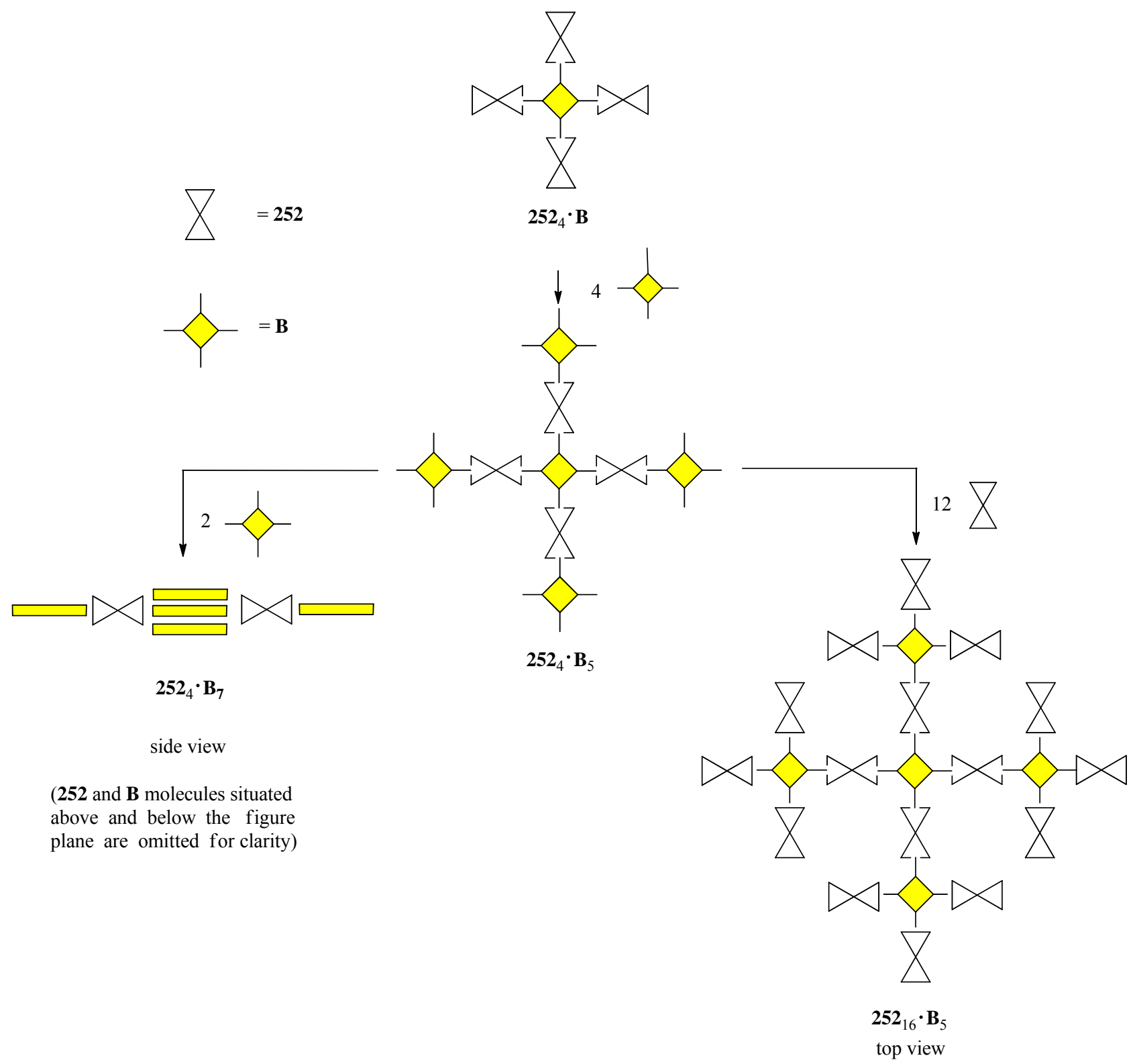

\section{Scheme 70}




\section{Conclusion}

The rapid development of research area of calixarenes observed today, results in a large amount of reports. One may believe that examples shown in the present review, albeit only selected, could provide some information connected with functionalization of these compounds. It is noteworthy that the properties of obtained functionalized calixarenes strongly depend on their structure.

Many works deal with calixarene complexes, ${ }^{150-153}$ among them complexes with metal ions, ${ }^{152,153}$ are of a great importance so for recovery as well as for removal of toxic metals from industrial sewages. Having in view the ecological safety one should also point out studies concerning the nuclear waste management. ${ }^{153}$

The works aiming to use calixarenes for construction of systems adsorbing gases such as hydrogen, ${ }^{154}$ or methane, ${ }^{155}$ are of interest in the field of energetics, and the development of these

investigations is expected. A growing attention is paid today to a wide range of sensors, ${ }^{156,157}$ as well as to removal of undesired compounds from industrial waste, ${ }^{158-160}$ this research area being strongly connected with the environment protection.

\section{Acknowledgement}

The financial support of this work provided by Polish Science Foundation (Grant NN 209441539) is gratefully acknowledged.

\section{References}

1. Gutsche, C. D. Calixarenes: An Introduction, Monographs in Supramolecular Chemistry, Royal Soc. Chem., Cambridge 2008.

2. Vicens, J.; Harrowfield, J. (Eds.) Calixarenes in the Nanoworld, Springer Verlag, Dordrecht 2007.

3. Joseph, R., Rao, C. P. Chem. Rev. 2011, dx.doi.org/10/1021/cr1004524.

4. Mokhtari, B., Pourabdollah, K., Dalali, N. J. Coord. Chem. 2011, 64, 743.

5. Mokhtari, B.; Pourabdollah, K.; Dalali, N. J. Radioanalytical and Nuclear Chemistry 2011, 287, 921.

6. Mokhtari, B.; Pourabdollah, K.; Dalali, N. J. Incl. Phenom. Macrocycl. Chem. 2011, 69, 1.

7. Han, C.; Li, H. Anal. Bioanal. Chem. 2010, 397, 1437.

8. Creaven, B.S.; Donion, D.F.; McGinley, J. Coord. Chem. Rev. 2009, 253, 893.

9. Leray, I.; Valeur, B. Eur. J. Inorg. Chem. 2009, 3525.

10. Xiao, Y.; Chung, T.S. Energy Environ. Sci. 2011, 4, 201.

11. Laza-Knoerr, A.; Huang, N.; Grossiord, J.L.; Couvreur, P.; Gref, R. J. Incl. Phenom. Macrocycl. Chem. 2011, 69, 475. 
12. Kozlowski, C.A.; Sliwa, W. Use of Cyclodextrin Polymers in Separation of Organic Species, Nova Science Publishers, Inc., New York 2010, and Chapter 4, pp 127-165 in the book "Carbohydrate Polymers: Development, Properties and Applications", Polymer Science and Technology Series, Nova Science Publishers, Inc., New York 2010.

13. Kozlowski, C.A.; Sliwa, W.; Nowik-Zajac, A. Chapter 7, pp 141-161 in the book "Cyclodextrins: Chemistry and Physics", J. Hu (Ed), Transworld Research Network, Kerala, India 2010.

14. Sueldo Occello, V.N.; Veglia, A.V. Anal. Chim. Acta 2011, 689, 97.

15. Premkumar, T.; Lee, Y.; Geckeler, K.E. Chem. Eur. J. 2010, 16, 11563.

16. Dutta Choudhury, S.; Mohanty, J.; Bhasikuttan, A.C.; Pal, H. J. Phys. Chem. 2010, 114B, 10717

17. Yin, J.; Chi, C.; Wu, J. Org. Biomol. Chem. 2010, 8, 2594.

18. Da Silva, D.L.; do Couto Tavares, E.; de Souza Conegero, L.; de Fatima, A.; Pilli, R.A.; Fernandes, S.A. J. Incl. Phenom. Macrocycl. Chem. 2011, 69, 149.

19. Cui, J.; Uzunova, V.D.; Guo, D.S.; Wang, K.; Nau, W.M.; Liu, Y. Eur. J. Org. Chem. 2010, 1704.

20. Galán, H.; Hennrich, G.; de Mendoza, J.; Prados, P. Eur. J. Org. Chem. 2010, 1249.

21. Bingol, H.; Kocabas, E.; Zor, E.; Coskun, A. Electrochim. Acta 2011, 56, 2057.

22. Harrowfield, J.M.; Ogden, M.I.; Skelton, B.W.; White, A.H. Dalton Trans. 2010, 39, 8313.

23. Lee, Y.H.; Lee, M.H.; Zhang, J.F.; Kim, J.S. J. Org. Chem. 2010, 75, 7159.

24. Galletta, M.; Baldini, L.; Sansone, F.; Ugozzoli, F.; Ungaro, R.; Casnati, A.; Mariani, M. Dalton Trans. 2010, 39, 2546.

25. Atanassova, M.; Lachkova, V.; Vassilev, N.; Varbanov, S.; Dukov, I. Polyhedron 2010, $29,655$.

26. Menon, S.K.; Modi, N.R.; Patel, B.; Patel, M.B. Talanta 2011, 83, 1329.

27. Kumar, M.; Bhalla, V.; Dhir, A.; Babu, J.N. Dalton Trans. 2010, 39, 10116.

28. Lee, Y.H.; Liu, H.; Lee, J. Y.; Kim, S.H.; Kim, S.K.; Sessler, J.L.; Kim, Y.; Kim, J.S. Chem. Eur. J. 2010, 16, 5895.

29. Espinas, J.; Darbost, U.; Pelletier, J.; Jeanneau, E.; Duchamp, C.; Bayard, F.; Boyron, O.; Broyer, J.P.; Thivolle-Cazat, J.; Basset, J.M.; Taoufik, M.; Bonnamour, I. Eur. J. Inorg. Chem. 2010, 1349.

30. Monnereau, L.; Sémeril, D.; Matt, D. Eur. J. Org. Chem. 2010, 3068.

31. Luo, J.; Shen, L.C.; Chung, W.S. J. Org. Chem. 2010, 75, 464.

32. Shirakawa, S.; Kimura, T.; Murata, S.; Shimizu, S. J. Org. Chem. 2009, 74, 1288.

33. Qiao, X.F.; Zhang, H.Y.; Yan, B. Dalton Trans. 2010, 39, 8882.

34. Haino, T.; Hirai, E.; Fujiwara, Y.; Kashihara, K. Angew. Chem. Int. Ed. 2010, 49, 7899.

35. Xu, S; Kudo, H.; Nishikubo, T.; Nakamura, S.; Numata, S. J. Polymer Sci. Part A, Polym. Chem. 2010, 48, 1931.

36. Leontiev, A.V.; Jemmett, C.A.; Beer, P.D. Chem. Eur. J. 2011, 17, 816.

37. Valeur, B.; Leray, I.; Zhao, L.; Souchon, V.; Métivier, R.; Plaza, P.; Ley, C.; Lacombat, F.; Martin, M.M. Chem. Phys. Chem. 2010, 11, 2416.

38. Gattuso, G.; Notti, A.; Parisi, M.F.; Pisagatti, I.; Amato, M.E.; Pappalardo, A.; Pappalardo, S. Chem. Eur. J. 2010, 16, 2381. 
39. Kennedy, S.; Karotsis, G.; Beavers, C.M.; Teat, S.J.; Brechin, E.K.; Dalgarno, S.J. Angew. Chem. Int. Ed. 2010, 49, 4205.

40. Kennedy, S.; Teat, S.J.; Dalgarno, S.J. Dalton Trans. 2010, 39, 384.

41. Wang, K.; Guo, D.-S.; Liu, Y. Chem. Eur. J. 2010, 16, 8006.

42. Pescatori, L.; Boccia, A.; Ciesa, F.; Rossi, F.; Grillo, V.; Arduni, A.; Pochini, A.; Zanoni, R.; Secchi, A. Chem. Eur. J. 2010, 16, 11089.

43. Lascaux, A.; Le Gac, S.; Wouters, J.; Luhmer, M.; Jabin, I. Org. Biomol. Chem. 2010, 8, 4607.

44. Moerkerke, S.; Ménand, M.; Jabin, I. Chem. Eur. J. 2010, 16, 11712.

45. Kleinhans, D.J.; Arnott, G.E. Dalton Trans. 2010, 39, 5780.

46. Kuzmicz, R.; Kowalska, V.; Domagala, S.; Stachowicz, M.; Wozniak, K.; Kolodziejski, W. J. Phys. Chem. 2010, 114B, 10311.

47. Benosmane, N.; Guedioura, B.; Hamdi, S.M.; Hamdi, M.; Boutemeur, B. Materials Science and Engineering C. 2010, 30, 860.

48. Durola, F.; Rebek, J. Jr., Angew. Chem. Int. Ed. 2010, 49, 3189.

49. Pochorovski, I.; Breiten, B.; Schweizer, W.B.; Diederich, F. Chem. Eur. J. 2010, 16, 12590.

50. Nishimura, N.; Kobayashi, K. J. Org. Chem. 2010, 75, 6079.

51. Negin, S.; Daschbach, M.M.; Kulikov, O.V.; Rath, N.; Gokel, G.W. J. Am. Chem. Soc. 2011, $133,3234$.

52. Jin, P.; Dalgarno, S.J.; Atwood, J.L. Coord. Chem. Rev. 2010, 254, 1760.

53. Yang, Y.; Arora, G.; Fernandez, F.A.; Crawford, J.D.; Surowiec, K.; Lee, E.K.; Bartsch, R.A. Tetrahedron 2011, 67, 1389.

54. Haddadi, H.; Alizadeh, N.; Shamsipur, M.; Asfari, Z. J. Phys. Chem. 2010, 114A, 7462.

55. Genorio, B.; Pirnat, K.; Cerc-Korosec, R.; Dominko, R.; Gaberscek, M. Angew. Chem. Int. Ed. 2010, 49, 7222.

56. Santos, S.M.; Costa, P.J.; Lankshear, M.D.; Beer, P.D.; Félix, V. J. Phys. Chem. 2010, 114B, 11173.

57. Yano, M.; Tong, C.C.; Light, M.E.; Schmidtchen, F.P.; Gale, P.A. Org. Biomol. Chem. 2010, 8, 4356.

58. Park, J.S.; Le Derf, F.; Bejger, C.M.; Lynch, V.M.; Sessler, J.L.; Nielsen, K.A.; Johnsen, C.; Jeppesen, J.O. Chem. Eur. J. 2010, 16, 848.

59. Journot, G.; Letondor, C.; Neier, R.; Stoeckli-Evans, H.; Savoia, D.; Gualandi, A. Chem. Eur. J. 2010, 16, 4224.

60. Horniček, J.; Dvořákova, H.; Bouř, P. J. Phys. Chem. 2010, 114A, 3649.

61. Bucher, C.; Devillers, C.H.; Moutet, J.C.; Royal, G.; Saint-Aman, E. Coord. Chem. Rev. 2009, 253, 21.

62. Ogoshi, T.; Kitajima, K.; Aoki, T.; Fujinami, S.; Yamagishi, T.; Nakamoto, Y. J. Org. Chem. 2010, 75, 3268.

63. Kou, Y.; Tao, H.; Cao, D.; Fu, Z.; Schollmeyer, D.; Meier, H. Eur. J. Org. Chem. 2010, 6464.

64. Cao, D.; Kou, Y.; Liang, J; Chen, Z.; Wang, L.; Meier, H. Angew. Chem. Int. Ed. 2009, 48, 9721.

65. Chen, M.; Zhang, W.; Jiang, R.; Diao, G. Anal. Chim. Acta 2011, 687, 177. 
66. Bilyk, A.; Dunlop, J.W.; Hall, A.K.; Harrowfield, J.M.; Hosseini, M.W.; Koutsantonis, G.A.; Skelton, B.W.; White, A.H. Eur. J. Inorg. Chem. 2010, 2089.

67. Kumar, M.; Dhir, A.; Bhalla, V. Dalton Trans. 2010, 39, 10122.

68. Capici, C.; Gattuso, G.; Notti, A.; Parisi, M.F.; Bruno, G.; Nicolo, F.; Pappalardo, S. Tetrahedron Lett. 2011, 52, 1351.

69. Van Rossom, W.; Kundrat, O.; Ngo, T.H.; Lhotak, P.; Dehaen, W.; Maes, W. Tetrahedron Lett. 2010, 51, 2423.

70. Maes, W.; Dehaen, W. Chem. Soc. Rev. 2008, 37, 2393.

71. Ishibashi, K.; Tsue, H.; Takahashi, H.; Tamura, R. Tetr. Asymm. 2009, 20, 375.

72. Clayden, J.; Rowbottom, S.J.M.; Ebenezer, W.J.; Hutchings, M.G. Org. Biomol. Chem. 2009, 7, 4871.

73. Wang, M.X. Chem. Commun. 2008, 4541.

74. Sliwa, W.; Kozlowski, C. Calixarenes and Resorcinarenes. Synthesis, Properties and Applications, Wiley-VCH, Weinheim 2009.

75. Sliwa, W.; Girek, T. J. Incl. Phenom. Macrocycl. Chem. 2010, 66, 15.

76. Sliwa, W.; Deska, M. Arkivoc 2008, (i), 87.

77. Deska, M.; Sliwa, W. Covalently and noncovalently bound assemblies of calixarenes, Nova Science Publishers, Inc., New York 2011.

78. Sliwa, W.; Peszke, J. Minirev. Org. Chem. 2007, 4, 125.

79. Sliwa, W. Arkivoc 2006, 5, 137.

80. Sliwa, W.; Dondela, B. Arkivoc 2007, (ii), 201.

81. Monnereau, C.; Rebilly, J.N.; Reinaud, O. Eur. J. Org. Chem. 2011, 166.

82. Torvinen, M.; Neitola, R.; Sansone, F.; Baldini, L.; Ungaro, R.; Casnati, A.; Vainiotalo, P;

Kalenius, E. Org. Biomol. Chem. 2010, 8, 906.

83. Rudzevich, Y.; Rudzevich, V.; Böhmer, V. Chem. Eur. J. 2010, 16, 4541.

84. Sameni, S.; Jeunesse, C.; Awada, M.; Matt, D.; Welter, R. Eur. J. Inorg. Chem. 2010, 4917.

85. Vovk, A.I.; Kononets, L.A.; Tanchuk, V.Y.; Cherenok, S.O.; Drapailo, A.B.; Kalchenko, V.I.;

Kukhar, V.P. Bioorg. and Medicinal Chem. Lett. 2010, $20,483$.

86. Safa, K.D.; Mosaei Oskoei, Y. J. Organometallic Chem. 2010, 695, 505.

87. Sameni, S.; Lejeune, M.; Jeunesse, C.; Matt, D.; Welter, R. Dalton Trans. 2009, 7912.

88. Monnereau, L.; Sémeril, D.; Matt, D.; Toupet, L. Chem. Eur. J. 2010, 16, 9237.

89. Vovk, A.I.; Kalchenko, V.I.; Cherenok, S.A.; Kukhar, V.P.; Muzychka, O.V.; Lozynsky, M.O. Org. Biomol. Chem. 2004, 2, 3162.

90. Li, Z.; Chiu, H.; Kutateladze, A.G. Can. J. Chem. 2003, 81, 807.

91. Metay, E.; Duclos, M.C.; Pellet-Rostaining, S.; Lemaire, M.; Kannappan, R.; Bucher, C.; SaintAman, E; Chaix, C. Tetrahedron 2009, 65, 672.

92. Shaabani, B.; Shaghaghi, Z. Tetrahedron 2010, 66, 3259.

93. Cormode, D.P.; Evans, A.J.; Davis, J.J.; Beer, P.D. Dalton Trans. 2010, 39, 6532.

94. Suwinska, K.; Shkurenko, O.; Mbemba, C.; Leydier, A.; Jebors, S.; Coleman, A.W.; Matar, R.; Falson, P. New J. Chem. 2008, 32, 1988.

95. Gaeta, C.; Gregoli, L.; Martino, M.; Neri, P. Tetrahedron Lett. 2002, 43, 8875. 
96. Cecioni, S.; Faure, S.; Darbost, U.; Bonnamour, I.; Parrot-Lopez, H.; Roy, O; Taillefumier, C.; Wimmerová, M.; Praly, J. P.; Imberty, A.; Vidal, S. Chem. Eur. J. 2011, 17, 2146.

97. Özen Karakus, O.; Kazaz, C.; Deligöz, H. Spectrochim. Acta 2010, 75A, 1018.

98. Kivlehan, F.; Lefoix, M.; Moynihan, H. A.; Thompson, D.; Ogurstov, V. I.; Herzog, G.;

Arrigan, D. W. M. Electrochim. Acta 2010, 55, 3348.

99. Colleran, J. J.; Creaven, B.S.; Donlon, D. F.; McGinley, J. Dalton Trans. 2010, 39, 10928.

100. Huc, V.; Guérineau, V. Eur. J. Org. Chem. 2010, 2199.

101. Cecioni, S.; Lalor, R.; Blanchard, B.; Praly, J. P.; Imberty, A; Matthews, S. E.; Vidal, S. Chem. Eur. J. 2009, 15, 13232.

102. Al-Saraierh, H; Miller, D. O.; Georghiou, P.E. J. Org. Chem. 2005, 70, 8273.

103. Narumi, F.; Hattori, T.; Morohashi, N.; Matsumura, N.; Yamabuki, W.; Kameyama, H.;

Miyano, S. Org. Biomol. Chem. 2004, 2, 890.

104. Narumi, F.; Morohashi, N.; Matsumura, N.; Iki, N.; Kameyama, H.; Miyano, S. Tetrahedron

Lett. 2002, 43, 621.

105. Jung, H. S.; Kwon, P. S.; Lee, W.J.; Kim, J. I.; Hong, C. S.; Kim, J. W.; Yan, S.; Lee, J. Y.;

Lee, J. H.; Joo, T.; Kim, J. S. J. Am. Chem. Soc. 2009, 131, 2008.

106. Dhir, A.; Balla, V.; Kumar, M. Org. Lett. 2008, 10, 4891.

107. Ocak, U.; Ocak, M; Surowiec, K.; Bartsch, R. A.; Gorbunova, M.G.; Tu, C.; Surowiec, M.A. J. Incl. Phenom. Macrocycl. Chem. 2009, 63, 131.

108. Nolan, E. M.; Lippard, S. J. Chem. Rev. 2008, 108, 3443.

109. Gruber, T.; Fischer, C.; Felsmann, M; Seichter, W.; Weber, E. Org. Biomol. Chem. 2009, 7, 4904.

110. Sun, J.; Liu, D. M.; Wang, J.X.; Yan, C. G. J. Incl. Phenom. Macrocycl. Chem. 2009, 64, 317.

111. Matvieiev, Y. I.; Boyko, V. I.; Podoprigorina, A. A.; Kalchenko, V. I. J. Incl. Phenom.

Macrocycl. Chem. 2008, 61, 89.

112. Mahon, M. F.; McGinley, J.; Rooney, A. D.; Walsh, J. M. D. Tetrahedron 2008, 64, 11058.

113. Chawla, H. M.; Singh, S. P. Tetrahedron 2008, 64, 741.

114. Chawla, H. M.; Shrivastava, R.; Sahu, S.N. New J. Chem. 2008, 32, 1999.

115. Ben Salem, A.; Regnouf-de-Vains, J.-B. Tetrahedron Lett. 2003, 44, 6769.

116. Shimizu, S.; Moriyama, A.; Kito, K.; Sasaki, Y. J. Org. Chem. 2003, 68, 2187.

117. Nomura, E.; Hosoda, A.; Taniguchi, H. J. Org. Chem. 2001, 66, 8030.

118. Tairov, M. A.; Vysotsky, M. O.; Kalchenko, O. I.; Pirozhenko, V. V.; Kalchenko, V. I. J. Chem. Soc., Perkin Trans. 1 2002, 1405.

119. Hervé, G.; Hahn, D. U.; Hervé, A. C.; Goodworth, K. J.; Hill, A. M.; Hailes, H. C. Org.

Biomol. Chem. 2003, 1, 427.

120. Yang, Y.; Cao, X.; Surowiec, K.; Bartsch, R. A. J. Incl. Phenom. Macrocycl. Chem. 2010, 66, 163.

121. Capici, C.; De Zorzi, R.; Gargiulli, C.; Gattuso, G.; Geremia, S.; Notti, A.; Pappalardo, S.;

Parisi, M.F.; Puntoriero, F. Tetrahedron 2010, 66, 4987.

122. Uyanik, A.; Sen, N.; Yilmaz, M. Bioresource Technology 2011, 102, 4313. 
123. Kim, S. H.; Hamdi, A.; Lee, Y. H.; Lee, J. H.; Kim, J. S.; Vicens, J. J. Incl. Phenom.

Macrocycl. Chem. 2010, 66, 133.

124. Demirtas, H. N.; Bozkurt, S.; Durmaz, M.; Yilmaz, M.; Sirit, A. Tetrahedron 2009, 65, 3014.

125. Hamdi, A.; Lee, Y. H.; Kim, Y.; Kusumahastuti, D. K. A.; Ohto, K.; Abidi, R.; Vicens, J.

Tetrahedron Lett. 2009, 50, 540.

126. Capan, R.; Davis, F. Mater. Chem. Phys. 2011, 125, 883.

127. Solovyov, A. V.; Cherenok, S. O.; Kalchenko, O. I.; Atamas, L. I.; Kazantseva, Z. I.; Koshets,

I. A.; Tsymbal, I. F.; Kalchenko, V. I. J. Mol. Liquids 2011, 159, 117.

128. Solangi, I. B.; Bhatti, A. A.; Kamboh, M. A.; Memon, S.; Bhanger, M. I. Desalination 2011, 272, 98.

129. Liu, S.; Sandoval, C. A. J. Mol. Catalysis A., Chem. 2010, 325, 65.

130. Semeraro, M.; Arduini, A.; Baroncini, M.; Battelli, R.; Credi, A.; Venturi, M.; Pochini, A.;

Secchi, A.; Silvi, S. Chem. Eur. J. 2010, 16, 3467.

131. Curinova, P.; Pojarova, M.; Budka J.; Lang, K.; Stibor, I.; Lhotak, P. Tetrahedron 2010, 66, 8047.

132. Chen, Y. J.; Chung, W. S. Eur. J. Org. Chem. 2009, 4770.

133. Joseph, R.; Ramanujam, B.; Acharya, A.; Rao, C. P. J. Org. Chem. 2009, 74, 8181.

134. Kaur, N.; Singh, N.; Cairns, D.; Callan, J. F. Org. Lett. 2009, 11, 2229.

135. Chang, K. C.; Su, I. H.; Wang, Y. Y.; Chung, W.S. Eur. J. Org. Chem. 2010, 4700.

136. Ehrhart, J.; Planeix, J. M.; Kyritsakas-Gruber, N.; Hosseini, M. W. Dalton Trans. 2010, 39, 2137.

137. Ciesielski, A.; Piot, L.; Samori, P.; Jouaiti, A.; Hosseini, M. Adv. Mater. 2009, 21, 1131.

138. Nimse, S. B.; Nguyen, V.T.; Kim, J.; Kim, H. S.; Song, K. S.; Eoum, W. Y.; Jung, C. Y.; Ta,

V. T.; Seelam, S. R.; Kim, T. Tetrahedron Lett 2010, 51, 2840.

139. Kliachyna, M. A.; Yesypenko, O. A.; Pirozhenko, V. V.; Shishkina, S.V.; Shishkin, O. V.;

Boyko, V. I.; Kalchenko, V. I. Tetrahedron 2009, 65, 7085.

140. Meddeb-Limem, S.; Malezieux, B.; Herson, P.; Besbes-Hentati, S.; Said, H.; Blais, J.C.;

Bouvet, M. J. Phys. Org. Chem. 2005, 18, 1176.

141. Redon, S.; Li, Y.; Reinaud, O. J. Org. Chem. 2003, 68, 7004.

142. Sénèque, O.; Rondelez, Y.; Le Clainche, L.; Inisan, C.; Rager, M.N.; Giorgi, M.; Reinaud, O.

Eur. J. Inorg. Chem. 2001, 2597.

143. Danila, C.; Bolte, M.; Böhmer, V. Org. Biomol. Chem. 2005, 3, 172.

144. Jedukondalu, M.; Ravikanth, M. Coord. Chem. Rev. 2011, 255, 547.

145. Hikal, W.M.; Harmon, H.J., J. Material Science 2011, 46, 2273.

146. Venkatramaiah, N.; Venkatesan, R. Solid State Sciences 2011, 13, 616.

147. Werner, F.; Gnichwitz, J.F.; Marczak, R.; Palomares, E.; Peukert, W.; Hirsch, A.; Guldi, D.M.

J. Phys. Chem. 2010, 114B, 14671.

148. Gulino, F.G.; Lauceri, R.; Frish, L.; Evan-Salem, T.; Cohen, Y.; De Zorzi, R.; Geremia, S.; Di

Costanzo, L.; Randaccio, L.; Sciotto, D.; Purrello, R. Chem. Eur. J. 2006, 12, 2722.

149. D’Urso, A.; Cristaldi, D.A.; Fragala, M.E.; Gattuso, G.; Pappalardo, A.; Villari, V.; Micali, N.;

Pappalardo, S.; Parisi, M.F.; Purrello, R. Chem. Eur. J. 2010, 16, 10439. 
150. Chen, M.; Shang, T.; Liu, J.; Diao, G. J. Chem. Thermodynamics 2011, 43, 88.

151. Gharib, F.; Hajmalek, M.; Alamoti, R. A.; Farajtabar, A. J. Mol. Liquids 2011, 159, 161.

152. Hajipour, A. R.; Habibi, S.; Ruoho, A. E. J. Incl. Phenom. Macrocycl. Chem. 2011, 69, 107.

153. Karavan, M.; Arnaud-Neu, F.; Hubscher-Bruder, V.; Smirnov, I.; Kalchenko, V. J. Incl.

Phenom. Macrocycl. Chem. 2010, 66, 113.

154. Alavi, S.; Woo, T. K.; Sirjoosingh, A.; Lang, S.; Moudrakovski, I.; Ripmeester, J. A. Chem.

Eur. J. 2010, 16, 11689.

155. Tedesco, C.; Erra, L.; Brunelli, M.; Cipolletti, V.; Gaeta, C.; Fitch, A. N.; Atwood, J. L.; Neri, P. Chem. Eur. J. 2010, 16, 2371.

156. Kim, S. H.; Hwang, I. J.; Gwon, S. Y.; Burkinshaw, S. M.; Son, Y.-A. Dyes and Pigments 2011, 88, 84.

157. Dinake, P.; Prokhorova, P. E.; Talanov, V. S.; Butcher, R. J.; Talanova, G. G. Tetrahedron Lett. 2010, 51, 5016.

158. Kamboh, M. A.; Solangi, I. B.; Sherazi, S. T. H.; Memon, S. J. Hazardous Materials 2011, 186, 651.

159. Memon, S.; Memon, N.; Memon, S.; Latif, Y. J. Hazardous Materials 2011, 186, 1696.

160. Sayin, S.; Ozcan, F.; Yilmaz, M. Desalination 2010, 262, 99. 